\title{
Synthesis and electrochemistry of annoquinone-A, cypripedin methyl ether, denbinobin and related 1,4-phenanthrenequinones
}

\author{
Karsten Krohn $^{* a}$, Ulrich Loock ${ }^{\mathrm{a}}$, Karin Paavilainen ${ }^{\mathrm{a}}$, Björn M. Hausen ${ }^{\mathrm{b},}$ Helmut W. \\ Schmalle $^{c}$, and Herbert Kiesele ${ }^{d}$ \\ ${ }^{a}$ Fachbereich Chemie und Chemietechnik, Universität Paderborn, Warburger Strasse 100, \\ 33098 Paderborn, Germany \\ ${ }^{b}$ Dermatologisches Zentrum Buxtehude, Funktionsbereich Allergologie, Am Krankenhaus 1, \\ 21614 Buxtehude, Germany \\ ${ }^{c}$ Anorganisch Chemisches Institut der Universität Zürich, Winterthurerstrasse 190, CH-8057 \\ Zürich, Switzerland \\ ${ }^{d}$ Drägerwerk AG, Moislinger Allee 53, 23558 Lübeck, Germany \\ E-mail: kk@chemie.uni-paderborn.de
}

(received 25 Oct 00; accepted 08 Nov 01; published on the web 16 Nov 01)

\begin{abstract}
The natural product annoquinone-A (1), the 1,4-phenanthrenequinones 41-75 and the 9,10dihydro-1,4-phenanthrenequinones 76-81 were prepared by Diels-Alder reaction of the styrenes 23-37 with the benzoquinones 38-40. The sterically hindered 5-methoxy compounds, which adopt a twisted conformation as shown by X-ray analysis, are only formed in trace amounts or as the less hindered 9,10-dihydro-1,4-phenanthrenequinones 76-81. The twisted conformation also leads to characteristic changes in the NMR spectra and the redox potential. Reaction of methoxybenzoquinone with styrenes preferentially affords the 3methoxy-1,4-phenanthrenequinones. Selective ether cleavage of the 5-methoxy group in 60 leads to the natural product denbinobine (3). Small amounts of C-9 hydroxylated compounds (57, 66, 68, 73, and 75) were also formed in the Diels-Alder reactions. In an alternative synthesis, using the photocylization of the stilbenes 84-87 followed by CAN oxidation, the 1,4-phenanthrenequinones 45, 51, 59 [methyl ether of cyprepidine (2)], 92 and the 1,2phenanthrenequinone 93 were prepared. The Thiele-Winter reaction of 41, 55, and 56 yields
\end{abstract}


mixtures of ca. 1:1 oxygenation at C-2 and C-3, thus complementing the Diels-Alder reaction in the preparation of 2-methoxy-1,4-phenanthrenequinones. The 1,4-phenanthrenequinones 46, 54, 67 are easily epoxidized with alkaline hydroperoxide to 102-104 in analogy to 1,4naphthoquinones.

Keywords: 1,4-Phenanthrenquinones, Diels-Alder reaction, photocylization of stilbenes, CAN oxidation, Thiele-Winter reaction, epoxidation

\section{Introduction}

Phenanthrenequinones of non-terpenoide origin occur relatively rarely in the plant kingdom, ${ }^{1-}$

5 whereas highly oxygenated phenanthrenes such as orchinol or hircinol from orchids ${ }^{6-12}$ playing an important role as phytoalexins (review ${ }^{13}$ ), are more widely distributed. Other hydroxy- or methoxyphenanthrenes have been used in traditional medicine and were isolated from Tannus communis, ${ }^{14}$ Combretum species (termite resistant, ${ }^{5,15,16}$ tropical hardwood $^{17}$ ), or more recently from Eulophia nuda. ${ }^{18,19}$ Some of the phenanthrenequinones isolated from various sources may be derived from the hydroxylated phenanthrenes by oxidation.

Three major groups of 1,4-phenanthrenequinones may be distinguished according to their structure and biosynthesis. Representatives of the first group are hydroxy- and methoxysubstituted compounds such as annoquinone-A (1), ${ }^{1}$ cypripedine (2), ${ }^{3,20}$ denbinobine (3) ${ }^{21}$ and combrestatin C-1 (4). ${ }^{5}$ An example for a phenylated 1,4-phenanthrenequinone is latinone (5), isolated from east Indian rosewood (Dalbergia latifolia Roxb.). ${ }^{4}$ The third and largest group comprises diterpene derived alkylated 1,4-phenanthrenequinones related to the abietanes; plectranthone A (6) isolated by Eugster, Rüedi et al. from Plectranthus sp. is just one example. $^{22,23}$ The group of the tanshinones is probably also derived from diterpenes. They comprise mostly furan-fused 1,2- and 1,4-phenanthrenequinones and are constituents of the chinese drug Dan Shen. ${ }^{24}$ Antimicrobial and cytostatic properties have been described for annoquinone-A (1) ${ }^{1}$ and combrestatin $\mathrm{C}-1(\mathbf{5}) .^{5}$ 


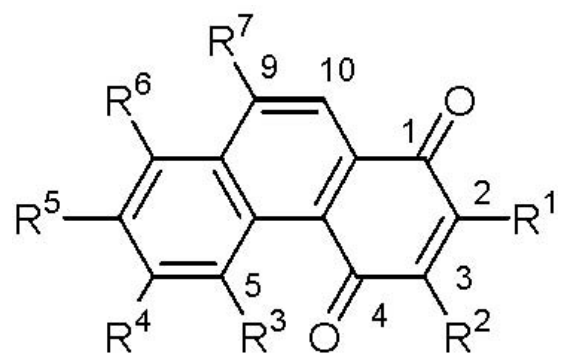

Figure 1. Structures of diverse naturally occurring 1,4-phenanthrenequinones.

\begin{tabular}{lccccccc}
\hline & $\mathrm{R}^{1}$ & $\mathrm{R}^{2}$ & $\mathrm{R}^{3}$ & $\mathrm{R}^{4}$ & $\mathrm{R}^{5}$ & $\mathrm{R}^{6}$ & $\mathrm{R}^{7}$ \\
\hline Annoquinone-A (1) $^{1}$ & $\mathrm{H}$ & $\mathrm{OMe}$ & $\mathrm{H}$ & $\mathrm{H}$ & $\mathrm{H}$ & $\mathrm{H}$ & $\mathrm{H}$ \\
Cypripedin (2) & $\mathrm{OMe}$ & $\mathrm{H}$ & $\mathrm{H}$ & $\mathrm{H}$ & $\mathrm{OH}$ & $\mathrm{OMe}$ & $\mathrm{H}$ \\
Denbinobine (3) $^{21}$ & $\mathrm{H}$ & $\mathrm{OMe}$ & $\mathrm{OH}$ & $\mathrm{H}$ & $\mathrm{OMe}$ & $\mathrm{H}$ & $\mathrm{H}$ \\
Combretastatin C-1 (4) $^{5}$ & $\mathrm{OMe}$ & $\mathrm{OMe}$ & $\mathrm{H}$ & $\mathrm{OMe}$ & $\mathrm{OH}$ & $\mathrm{H}$ & $\mathrm{H}$ \\
Latinone (5) $^{25}$ & $\mathrm{OMe}$ & $\mathrm{H}$ & $\mathrm{H}$ & $\mathrm{OMe}$ & $\mathrm{OH}$ & $\mathrm{H}$ & $\mathrm{H}$ \\
Plectranthone A (6) $^{11}$ & $\mathrm{allyl}$ & $\mathrm{OH}$ & $\mathrm{Me}$ & $\mathrm{H}$ & $\mathrm{Me}$ & $\mathrm{Me}$ & $\mathrm{H}$ \\
\hline
\end{tabular}

Unfortunately, 1,2- and 1,4-phenanthrenequinones also exhibit allergenic properties. Contact dermatitis of the hands and the face were described by botanists collecting fieldgrown lady's slippers as early as $1875^{26}$ and $1894 .^{27}$ Recently, the first allergenic 1,4phenanthrenequinone cypripedine (2) was isolated from Cypripedium calceolus ${ }^{3}$ and the east Indian rosewood (Dalbergia latifolia) containing latinone (4) ${ }^{4}$ is also known for allergyinducing properties. $^{15}$

In order to learn more about the relationship of structure and sensitizing properties, ${ }^{28}$ and to study the chemistry and electrochemistry a number of known and new 1,4phenanthrenequinones belonging to the first group were synthesized. Two methods were applied in the synthesis of 1,4-phenanthrenequinones. A direct method is the Diels-Alder reaction of styrenes and benzoquinones, ${ }^{1,4}, 29-35$ that leads to the substituted phenanthrenequinones or the corresponding dihydo compounds as depicted in Scheme 1. Recently, this synthesis has been used in connection with the preparation of the carcinogenic benz $[a]$ anthracenes. ${ }^{36,31}$ 
In the second method, oxygenated phenanthrenes are oxidized to the corresponding quinones. The presence of hydroxy or methoxy groups in ring $\mathrm{A}$ is necessary to avoid the easily occurring oxidation to 9,10-phenanthrenequinones. The photocyclization of stilbenes was used to prepare the required phenanthrenes. This approach gives complementary results to the Diels-Alder reaction with respect to the substitution pattern of the phenanthrene skeleton $^{5,7,37,38}$ (for reviews see, ${ }^{39,40}$ for an alternative Lewis acid-mediated cyclizationdehydration sequence see ${ }^{41}$ ).

The alkoxylated styrenes 23-37 (Scheme 1) used in the Diels-Alder reaction with the benzoquinones 38-40 were prepared in 92-98\% yield from the benzaldehydes 7-21 in a Wittig reaction employing the procedure of Boden ${ }^{42}$ (see experimental part, general procedure II). The aldehydes 7-18 are commercially available and the benzyl ethers 19 and 21 were prepared by benzylation of the corresponding phenols ${ }^{43}$ (see experimental part, general procedure I). The unknown benzyl ether 20, required for the synthesis of cyprepidine, was obtained by selective acetylation of 2,3-dihydroxybenzaldehyde to 3-acetoxy-2hydroxybenzaldehyde, ${ }^{44}$ methylation to 3-acetoxy-2-methoxybenzaldehyde 22, followed by benzylation with simultaneous acetate cleavage to afford the mixed benzylmethyl ether 23 in $60 \%$ overall yield.

\section{Diels-Alder reactions}

Diels-Alder reactions with stilbenes, in which the double bond of the aromatic system is part of the diene, were first reported by Hudson and Robinson ${ }^{45}$ and by Buckner ${ }^{46}$ (for reviews see ref. $^{47,48}$ ). In the reactions of 23-37 a fivefold excess of the benzoquinones 38-40 was used to afford the 1,4-phenanthrenequinones $\mathbf{1}$ and 41-75 in addition to the 1,4dihydrophenanthrenequinones 76-81 (see experimental part, general procedure III). The excess of benzoquinones was necessary for dehydrogenation of the intermediate dihydro-1,4phenanthrenequinones resulting from tautomerisation of the direct Diels-Alder adducts (for discussion of the intermediates $\mathrm{see}^{47}$ ). The reaction was catalyzed by small amounts of trichloroacetic acid ${ }^{29}$ and the catalytic activity may in part be attributed to acceleration of the isomerization processes. Reaction times, yields and melting points of the and 9,10-dihydro1,4-phenanthrenequinones are summarized in Table 1.

The 9,10-dihydro-1,4-phenanthrenequinones 76, 78, 79, and 81 were isolated in four cases together with the corresponding unsaturated 1,4-phenanthrenequinones 44, 51, 54, and 69 . In 
two reactions, the dihydro compounds $\mathbf{7 7}$ and $\mathbf{8 0}$ were the only products isolated in the DielsAlder reactions. Dehydrogenation of the 9,10-dihydro-phenanthrenequinones 79 and 80 to 54 and 60 could be achieved by treatment with palladium-charcoal at $184{ }^{\circ} \mathrm{C}$ in good yield (see experimental part, general procedure IV).

The ${ }^{1} \mathrm{H}-\mathrm{NMR}$ spectral data of the six monomethoxy-1,4-phenanthrenequinones $(\mathbf{1}, \mathbf{4 2}-\mathbf{4 6})$ served to calculate increment values for the chemical shift differences to the unsubstituted 1,4-phenanthrenequinone 41 listed in Table 2. These data served to unambiguously assign the regioisomers formed in the Diels-Alder reaction of styrenes with methoxybenzoquinone 39 (see below). Comparison of calculated and measured values (see experimental part) showed excellent additivity of these increments in all 1,4-phenanthrenequinones with exception of those with neighboring methoxy groups. Minor deviations from this linear effect were only seen in ortho-disubstituted 1,4-phenanthrenequinones.

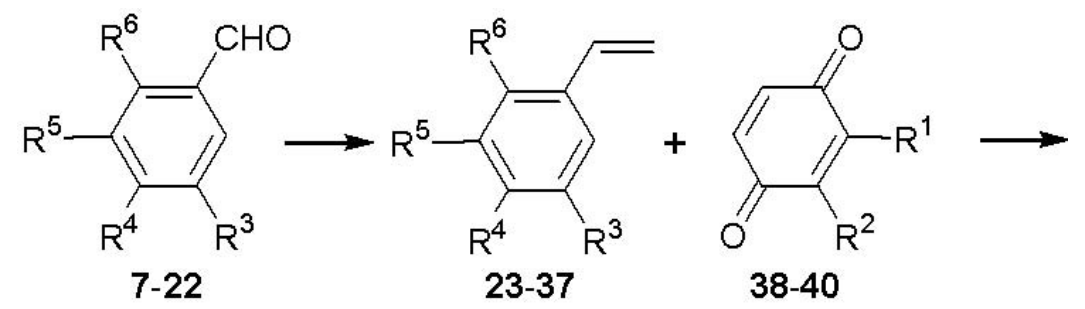

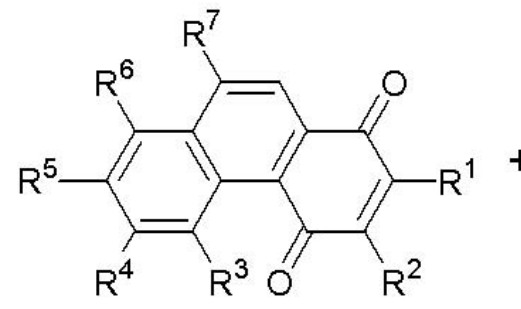

1, 41-75

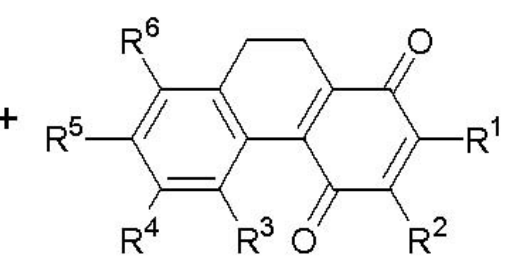

76-81

Scheme 1. Diels-Alder reaction of styrenes and benzoquinones leading to 1,4phenanthrenequinones and 9,10-dihydro-1,4-phenanthrenequinones 


\begin{tabular}{|c|c|c|c|c|c|}
\hline $\mathrm{ArCHO}$ & $\mathrm{R}^{3}$ & $\mathrm{R}^{4}$ & $\mathrm{R}^{5}$ & $\mathrm{R}^{6}$ & $\mathrm{ArCH}=\mathrm{CH}_{2}$ \\
\hline 7 & $\mathrm{H}$ & $\mathrm{H}$ & $\mathrm{H}$ & $\mathrm{H}$ & 23 \\
\hline 8 & $\mathrm{H}$ & $\mathrm{H}$ & $\mathrm{H}$ & $\mathrm{OMe}$ & 24 \\
\hline 9 & $\mathrm{H}$ & $\mathrm{H}$ & $\mathrm{OMe}$ & $\mathrm{H}$ & 25 \\
\hline 10 & $\mathrm{H}$ & $\mathrm{OMe}$ & $\mathrm{H}$ & $\mathrm{H}$ & 26 \\
\hline 11 & $\mathrm{H}$ & $\mathrm{H}$ & $\mathrm{OMe}$ & $\mathrm{OMe}$ & 27 \\
\hline 12 & $\mathrm{H}$ & $\mathrm{OMe}$ & $\mathrm{H}$ & $\mathrm{OMe}$ & 28 \\
\hline 13 & $\mathrm{OMe}$ & $\mathrm{H}$ & $\mathrm{H}$ & $\mathrm{OMe}$ & 29 \\
\hline 14 & $\mathrm{H}$ & $\mathrm{OMe}$ & $\mathrm{OMe}$ & $\mathrm{H}$ & 30 \\
\hline 15 & $\mathrm{OMe}$ & $\mathrm{H}$ & $\mathrm{OMe}$ & $\mathrm{H}$ & 31 \\
\hline 16 & $\mathrm{H}$ & $\mathrm{OMe}$ & $\mathrm{OMe}$ & $\mathrm{OMe}$ & 32 \\
\hline 17 & $\mathrm{OMe}$ & $\mathrm{OMe}$ & $\mathrm{H}$ & $\mathrm{OMe}$ & 33 \\
\hline 18 & $\mathrm{OMe}$ & $\mathrm{OMe}$ & $\mathrm{OMe}$ & $\mathrm{H}$ & 34 \\
\hline 19 & $\mathrm{H}$ & $\mathrm{H}$ & $\mathrm{OMe}$ & OBzl & 35 \\
\hline 20 & $\mathrm{H}$ & $\mathrm{H}$ & OBzl & $\mathrm{OMe}$ & 36 \\
\hline 21 & $\mathrm{H}$ & $\mathrm{OMe}$ & OBzl & $\mathrm{H}$ & 37 \\
\hline 22 & $\mathrm{H}$ & $\mathrm{H}$ & OAc & $\mathrm{OMe}$ & - \\
\hline
\end{tabular}

Table 1. Reaction times, yields, and melting points of 1,4-phenanthrenequinones (1, 41-75) and of 8,9-dihydro-1,4-phenanthrenequinones (76-81)

\begin{tabular}{|c|c|c|c|c|c|c|c|c|c|c|c|c|c|c|}
\hline $\mathrm{PQ}$ & $\mathrm{R}^{1}$ & $\mathrm{R}^{2}$ & $\mathrm{R}^{3}$ & $\mathrm{R}^{4}$ & $\mathrm{R}^{5}$ & $\mathrm{R}^{6}$ & $\mathrm{R}^{7}$ & $\begin{array}{c}\text { Time } \\
\text { [d] }\end{array}$ & $\begin{array}{c}\text { Yield } \\
{[\%]}\end{array}$ & $\begin{array}{l}\text { m.p. } \\
{\left[{ }^{\circ} \mathrm{C}\right]}\end{array}$ & $\begin{array}{l}\text { Ref. } \\
\text { m.p. } \\
{ }^{\circ} \mathrm{C}^{29}\end{array}$ & $\begin{array}{l}\mathrm{PQ} \\
\mathrm{H}_{2}\end{array}$ & $\begin{array}{c}\text { Yield } \\
{[\%]}\end{array}$ & $\begin{array}{l}\text { m.p. } \\
{\left[{ }^{\circ} \mathrm{C}\right]}\end{array}$ \\
\hline 41 & $\mathrm{H}$ & $\mathrm{H}$ & $\mathrm{H}$ & $\mathrm{H}$ & $\mathrm{H}$ & $\mathrm{H}$ & $\mathrm{H}$ & 6 & 14 & 143 & 145 & - & & \\
\hline 42 & $\mathrm{OMe}$ & $\mathrm{H}$ & $\mathrm{H}$ & $\mathrm{H}$ & $\mathrm{H}$ & $\mathrm{H}$ & $\mathrm{H}$ & 17 & 1 & 135 & & - & & \\
\hline 1 & $\mathrm{H}$ & $\mathrm{OMe}$ & $\mathrm{H}$ & $\mathrm{H}$ & $\mathrm{H}$ & $\mathrm{H}$ & $\mathrm{H}$ & 17 & 14 & 170 & $\begin{array}{l}170- \\
172^{1}\end{array}$ & - & & \\
\hline 43 & $\mathrm{H}$ & $\mathrm{H}$ & OMe & $\mathrm{H}$ & $\mathrm{H}$ & $\mathrm{H}$ & $\mathrm{H}$ & 18 & 2 & 111 & $\begin{array}{c}106.5- \\
108.5\end{array}$ & - & & \\
\hline 44 & $\mathrm{H}$ & $\mathrm{H}$ & $\mathrm{H}$ & $\mathrm{OMe}$ & $\mathrm{H}$ & $\mathrm{H}$ & $\mathrm{H}$ & 3 & 28 & 203 & $202-203$ & & & \\
\hline
\end{tabular}


Table 1. Continued

$\begin{array}{ccccccccccccccc}45 & \mathrm{H} & \mathrm{H} & \mathrm{H} & \mathrm{H} & \mathrm{OMe} & \mathrm{H} & \mathrm{H} & 18 & 15 & 153 & 153 & \mathbf{7 6} & 5 & 150 \\ 46 & \mathrm{H} & \mathrm{H} & \mathrm{H} & \mathrm{H} & \mathrm{H} & \mathrm{OMe} & \mathrm{H} & 4 & 30 & 208 & 208-209 & - & & \end{array}$

$\begin{array}{lllllllllll}47 & \mathrm{H} & \mathrm{OMe} & \mathrm{H} & \mathrm{OMe} & \mathrm{H} & \mathrm{H} & \mathrm{H} & 3 & 10 & 215\end{array}$

$\begin{array}{lllllllllll}48 & \mathrm{H} & \mathrm{OMe} & \mathrm{H} & \mathrm{H} & \mathrm{OMe} & \mathrm{H} & \mathrm{H} & 14 & 6 & 205\end{array}$

$\begin{array}{lllllllllll}49 & \mathrm{H} & \mathrm{OMe} & \mathrm{H} & \mathrm{H} & \mathrm{H} & \mathrm{OMe} & \mathrm{H} & 11 & 19 & 246-\end{array}$

$\begin{array}{lllllllll}- & \mathrm{H} & \mathrm{H} & \mathrm{OMe} & \mathrm{H} & \mathrm{OMe} & \mathrm{H} & \mathrm{H}\end{array}$

$\begin{array}{lll}77 & 38 & 110\end{array}$

$\begin{array}{lllllllllllll}50 & \mathrm{H} & \mathrm{H} & \mathrm{OMe} & \mathrm{H} & \mathrm{H} & \mathrm{OMe} & \mathrm{H} & 4 & 18 & 176 & 173-175 & -\end{array}$

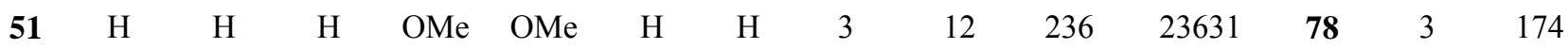

$\begin{array}{lllllllllll}52 & \mathrm{H} & \mathrm{H} & \mathrm{H} & \mathrm{OMe} & \mathrm{H} & \mathrm{OMe} & \mathrm{H} & 4 & 11 & 252\end{array}$

$\begin{array}{lllllllllll}53 & \mathrm{H} & \mathrm{H} & \mathrm{H} & \text { OBzl } & \text { OMe } & \mathrm{H} & \mathrm{H} & 3 & 66 & 153\end{array}$

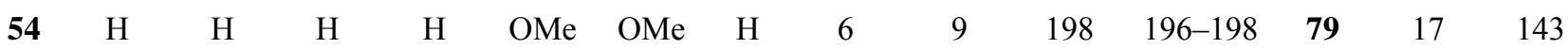

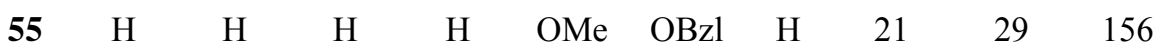

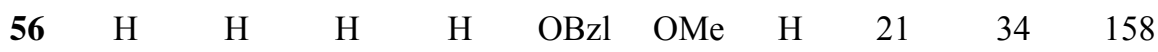

$\begin{array}{lllllllllll}57 & \mathrm{H} & \mathrm{H} & \mathrm{H} & \mathrm{H} & \mathrm{H} & \mathrm{OMe} & \mathrm{OH} & 4 & 0.6 & 238\end{array}$

$\begin{array}{lllllllllll}58 & \mathrm{OMe} & \mathrm{H} & \mathrm{H} & \mathrm{OMe} & \mathrm{H} & \mathrm{OMe} & \mathrm{H} & 3 & 2 & 253\end{array}$

$\begin{array}{lllllllllll}59 & \mathrm{OMe} & \mathrm{H} & \mathrm{H} & \mathrm{H} & \mathrm{OMe} & \mathrm{OMe} & \mathrm{H} & 8 & 1 & 166\end{array}$

$\begin{array}{lllllllllll}60 & \mathrm{H} & \mathrm{OMe} & \mathrm{OMe} & \mathrm{H} & \mathrm{OMe} & \mathrm{H} & \mathrm{H} & - & 0 & 167\end{array}$

$\mathbf{8 0} \quad 37 \quad 189$

$\begin{array}{lllllllllll}61 & \mathrm{H} & \mathrm{OMe} & \mathrm{OMe} & \mathrm{H} & \mathrm{H} & \mathrm{OMe} & \mathrm{H} & 5 & 15 & 219\end{array}$

$\begin{array}{lllllllllll}62 & \mathrm{H} & \mathrm{OMe} & \mathrm{H} & \mathrm{OMe} & \mathrm{OMe} & \mathrm{H} & \mathrm{H} & 4 & 12 & 250\end{array}$

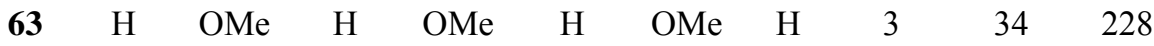

$\begin{array}{lllllllllll}64 & \mathrm{H} & \mathrm{OMe} & \mathrm{H} & \mathrm{H} & \mathrm{OMe} & \mathrm{OMe} & \mathrm{H} & 8 & 23 & 227\end{array}$

$\begin{array}{lllllllllll}65 & \mathrm{H} & \mathrm{H} & \mathrm{OMe} & \mathrm{OMe} & \mathrm{OMe} & \mathrm{H} & \mathrm{H} & 7 & 15 & 139\end{array}$

$\begin{array}{lllllllllll}66 & \mathrm{H} & \mathrm{H} & \mathrm{OMe} & \mathrm{H} & \mathrm{H} & \mathrm{OMe} & \mathrm{OH} & 4 & 3 & 169\end{array}$

$\begin{array}{lllllllllll}67 & \mathrm{H} & \mathrm{H} & \mathrm{H} & \mathrm{OMe} & \mathrm{OMe} & \mathrm{OMe} & \mathrm{H} & 4 & 48 & 139\end{array}$

$\begin{array}{lllllllllll}68 & \mathrm{H} & \mathrm{H} & \mathrm{H} & \mathrm{H} & \mathrm{OMe} & \mathrm{OMe} & \mathrm{OH} & 6 & 0.2 & 204\end{array}$

$\begin{array}{lllllllllll}69 & \mathrm{OMe} & \mathrm{OMe} & \mathrm{H} & \mathrm{H} & \mathrm{OMe} & \mathrm{OMe} & \mathrm{H} & 11 & 24 & 157\end{array}$

$81 \quad 12 \quad 125$

$\begin{array}{lllllllllll}70 & \mathrm{OMe} & \mathrm{H} & \mathrm{H} & \mathrm{OMe} & \mathrm{OMe} & \mathrm{OMe} & \mathrm{H} & 3 & 4 & 217\end{array}$

$\begin{array}{lllllllllll}71 & \mathrm{H} & \mathrm{OMe} & \mathrm{OMe} & \mathrm{OMe} & \mathrm{OMe} & \mathrm{H} & \mathrm{H} & 8 & 17 & 187\end{array}$

$\begin{array}{lllllllllll}72 & \mathrm{H} & \mathrm{OMe} & \mathrm{OMe} & \mathrm{OMe} & \mathrm{H} & \mathrm{OMe} & \mathrm{H} & 6 & 9 & 200-\end{array}$ 
Table 1. Continued

\begin{tabular}{cccccccccccc}
73 & $\mathrm{H}$ & $\mathrm{OMe}$ & $\mathrm{OMe}$ & $\mathrm{H}$ & $\mathrm{H}$ & $\mathrm{OMe}$ & $\mathrm{OH}$ & 5 & 2 & 231 & - \\
$\mathbf{7 4}$ & $\mathrm{H}$ & $\mathrm{OMe}$ & $\mathrm{H}$ & $\mathrm{OMe}$ & $\mathrm{OMe}$ & $\mathrm{OMe}$ & $\mathrm{H}$ & 3 & 46 & 195 & - \\
75 & $\mathrm{H}$ & $\mathrm{H}$ & $\mathrm{H}$ & $\mathrm{OMe}$ & $\mathrm{OMe}$ & $\mathrm{OMe}$ & $\mathrm{OH}$ & 3 & 2 & 217 & - \\
\hline
\end{tabular}

Table 2. Shift increments $[\Delta \mathrm{ppm}]$ of the proton signals in the ${ }^{1} \mathrm{H}$ NMR spectra of the monosubstitued 1,4-phenanthrenequinones 1, 42-46 compared with the unsubstituted 1,4phenanthrenequinone (41)

\begin{tabular}{ccccccc}
\hline Position of H & 42 & 1 & 43 & 44 & 45 & 46 \\
\hline $2-\mathrm{H}$ & - & -0.83 & -0.11 & 0 & -0.02 & -0.03 \\
$3-\mathrm{H}$ & -0.80 & - & 0.11 & 0 & 0 & .0 .06 \\
$5-\mathrm{H}$ & 0.06 & -0.05 & - & -0.48 & -0.05 & -048 \\
$6-\mathrm{H}$ & -0.02 & -0.04 & -0.67 & - & -0.32 & -0.13 \\
$7-\mathrm{H}$ & -0.01 & -0.05 & -0.06 & -0.34 & - & -0.71 \\
$8-\mathrm{H}$ & 0 & -0.03 & -0.42 & -0.09 & -0.68 & - \\
$9-\mathrm{H}$ & 0.04 & -0.03 & -0.10 & -0.05 & 0 & 0.49 \\
$10-\mathrm{H}$ & -0.03 & -0.01 & -0.15 & -0.11 & -0.08 & -0.07 \\
\hline
\end{tabular}

The formation of two different regioisomers was possible in the reaction of the styrenes 25, 30 and 32 with benzoquinone 38. The structures were assigned based on the increments shown in Table 2. Only in the reaction of 25, a 1,4-phenanthrenequinone 43 with a sterically hindered methoxy group at C-5 was formed in low yield (2\%) in addition to the major 7methoxy compound 45 (15\%). The sterically favored regioisomers 51 and 53 were the only products detected in the other cases. A sterically hindered methoxy group at C-5 was present in the products that furnished exclusively the 9,10-dihydro-1,4-phenanthrenequinones 77 and 80. Evidently, in the twisted dihydro compounds, there is less steric compression introduced by a 5-methoxy group than in the corresponding dehydrogenated 1,4phenanthrenequinones. ${ }^{49,50}$ The release of strain is also seen in the upfield shift of $5-\mathrm{H}$ resonance in the ${ }^{1} \mathrm{H}$ NMR spectra of the 9,10-dihydro compounds by almost $1 \mathrm{ppm}$ compared 
to the 1,4-phenanthrenequinones. A deviation from a totally flattened conformation is also adopted by the 1,4-phenanthrenequinone $\mathbf{6 1}$ as shown by X-ray structure determination. ${ }^{51}$ This is related to the skeletal deformation of related 4,5-disubstituted phenanthrenes and 9,10dihydro phenanthrenes. ${ }^{49}$ The possibility of forming 9,10-dihydro compounds by Diels-Alder reaction allows the synthesis of C-5 substituted 1,4-phenanthrenequinones by subsequent palladium catalyzed dehydrogenation. This is in contrast to the photocyclization of stilbenes where C-5 methoxylated phenanthrenes are not formed (see below).

The chromatographic analysis of the Diels-Alder reactions revealed the presence of polar hydroxylated 1,4-phenanthrenequinones in five cases. The position of the hydroxy group could not unambiguously be deduced from the spectral data alone. Therefore, an X-ray analysis was undertaken that proved the structure of $66 .{ }^{51}$ The phenolic groups in the other compounds were also located at C-9 as shown by comparison of their NMR spectra with 66 and the structures had to be represented as 57, 66, 68, 73, and 75, respectively. The origin of the oxygen atom introduced during the Diels-Alder reactions probably arises from air oxygen but the mechanistic pathway remains unclear at the present time.

Several regioisomers can theoretically be formed in the reaction of methoxybenzoquinone (39) with the styrenes 23-37. In practice, the number is reduced to two isomers because the addition occurs only at the non-substituted ethylene linkage of the benzoquinone, probably for steric as well as electronic reasons. ${ }^{30,47}$ However, two regioisomers result depending on the relative orientation of the styrene and the methoxybenzoquinone. There is a controversy in the literature concerning this stereochemical question. Kashisawa et al. ${ }^{30}$ state that 3-methoxy1,4-phenanthrenequinone (1) is formed in the reaction of styrene 7 with 39 in contrast to Lora-Tomaya $^{47}$ who deduced the C-2 position based on chemical degradation. The chemical shifts in the ${ }^{1} \mathrm{H}-\mathrm{NMR}$ spectra for the quinoide protons at C-2 or C-3 are too small to be significant ( $\Delta=0.06 \mathrm{ppm}$ for 1 and 42 ) but the ${ }^{13} \mathrm{C}-\mathrm{NMR}$ chemical shifts differ significantly and an assignment would be possible if the location of the methoxy group in compounds with a related structure would be know. The structures of two major products $\mathbf{4 9}$ and $\mathbf{6 4}$ from the reaction of the styrenes 23 and 26 with 39 were determined by X-ray analysis showing that the methoxy group was located at C-3. ${ }^{52}$ Comparison of the ${ }^{13} \mathrm{C}-\mathrm{NMR}$ spectra showed that all major regioisomers $(\mathbf{1}, \mathbf{6 3}, \mathbf{6 4}$, and $\mathbf{7 4})$ had a methoxy group at $\mathrm{C}-3$ and the minor isomers $\mathbf{4 2}$, 58, 59, and 70 had a methoxy group at C-2. In seven other cases $(47-49,61,62,71$, and 72$)$ the 3-methoxy-1,4-phenanthrenequinones were the only products that could be isolated in 
addition to the dihydro compound 77 . The physical and spectral properties of the major reaction product 1 were identical to those reported for the natural product annoquinone-A, the antimicrobial and cytotoxic compound isolated from Annona montana. ${ }^{1}$

\section{Photocyclization}

The photocyclization of stilbenes to phenanthrenes is probably one of the most often used photochemical reactions. ${ }^{39,40}$ The multistep conversion comprises isomerization of $E$-stilbenes to Z-stilbenes, followed by cyclization of intermediate radicals to dihydrophenanthrenes that are irreversibly dehydrogenated to phenanthrenes in the presence of oxidants. ${ }^{37}$ The stilbenes 84-87 required for our investigation were prepared by Wittig reaction using the procedure of Boden $^{42}$ starting form the aldehydes 11, 13 and $\mathbf{1 7}$ and the phosphonium salts 82 and $\mathbf{8 3}$. Upon irradiation of the stilbenes $\mathbf{8 4}, \mathbf{8 5}$, and $\mathbf{8 6}$, the photocyclization products 1,4,7trimethoxyphenanthrene $\mathbf{8 8}, \quad 1,2,7,8$-tetramethoxyphenanthrene $\mathbf{8 9}$, and 1,4,7,8tetramethoxyphenanthrene $\mathbf{9 0}$ were formed without loss of methoxy groups. As expected, only the sterically less hindered 7-methoxy compound $\mathbf{8 8}$ resulted from the photolysis of $\mathbf{8 4}$. The preferential formation of the less hindered regioisomer has also been observed in hydroxylated precursors. ${ }^{7}$ A methoxy group was eliminated during the irradiation of 87 yielding the 1,2,6,7-tetramethoxyphenanthrene 91 .

The subsequent oxidation to 1,4-phenanthrenequinones can be effected by ether cleavage followed by air oxidation ${ }^{31}$ or in one step using ceric ammonium nitrate (CAN). ${ }^{53,54}$ In the clean oxidation, the reagent preferentially cleaved the para-methoxy groups of the tri- and tetramethoxyphenanthrenes 88 and 90 to afford the 1,4-phenanthrenequinones $\mathbf{4 5}$ and 51. A separable mixture of the ortho-quinone 93 and the para-quinone 59 was isolated in the oxidation of 87. The 1,4-phenanthrenequinone 59 was identical with a methylated sample of the natural product cypripedine (2). A 1,4-phenanthrenequinone 92 of isomeric structure was obtained by CAN treatment of $\mathbf{8 9}$. The results demonstrate that 2-methoxy-1,4phenanthrenequinones and 1,2-phenanthrenequinones that are not easily accessible by DielsAlder reactions, but can be prepared efficiently by CAN oxidation from photochemically generated phenanthrenes (general procedure VIII). On the other hand, sterically hindered 4,5disubstituted phenanthrenes and thus their putative oxidation products, the 5-methoxy-1,4phenanthrenequinones, cannot be obtained by this route. 

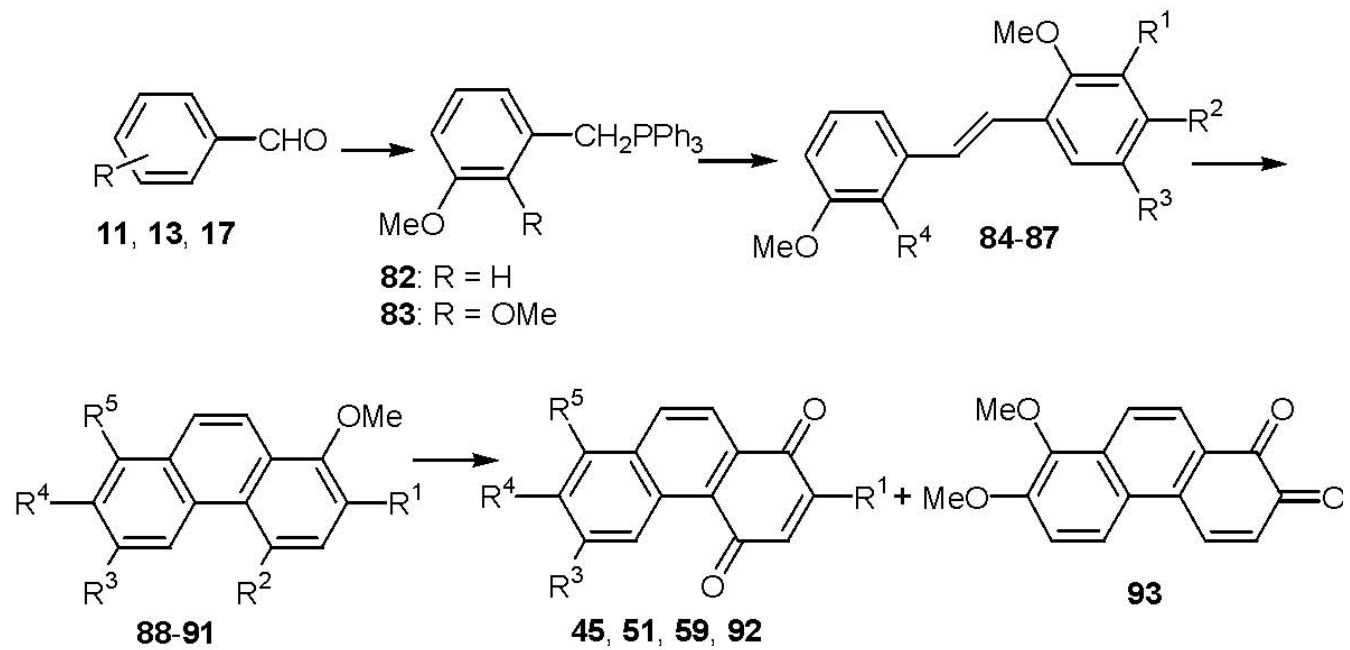

Scheme 2. Photocyclization of stilbenes (ST 84-87) to the phenanthrenes (PH 88-91) and CAN-oxidation to 1,4- and 1,2-phenanthrenequinones

\begin{tabular}{lllll}
$\mathrm{ST}$ & $\mathrm{R}^{1}$ & $\mathrm{R}^{2}$ & $\mathrm{R}^{3}$ & $\mathrm{R}^{4}$ \\
\hline $\mathbf{8 4}$ & $\mathrm{H}$ & $\mathrm{H}$ & $\mathrm{H}$ & $\mathrm{OMe}$ \\
$\mathbf{8 5}$ & $\mathrm{OMe}$ & $\mathrm{OMe}$ & $\mathrm{H}$ & $\mathrm{H}$ \\
$\mathbf{8 6}$ & $\mathrm{OMe}$ & $\mathrm{H}$ & $\mathrm{H}$ & $\mathrm{OMe}$ \\
$\mathbf{8 7}$ & $\mathrm{H}$ & $\mathrm{OMe}$ & $\mathrm{OMe}$ & $\mathrm{OMe}$ \\
\hline
\end{tabular}

\begin{tabular}{lllllll}
$\mathrm{PH}$ & $\mathrm{R}^{1}$ & $\mathrm{R}^{2}$ & $\mathrm{R}^{3}$ & $\mathrm{R}^{4}$ & $\mathrm{R}^{5}$ & $\mathrm{PQ}$ \\
\hline $\mathbf{8 8}$ & $\mathrm{H}$ & $\mathrm{OMe}$ & $\mathrm{H}$ & $\mathrm{OMe}$ & $\mathrm{H}$ & $\mathbf{4 5}$ \\
$\mathbf{8 9}$ & $\mathrm{OMe}$ & $\mathrm{H}$ & $\mathrm{OMe}$ & $\mathrm{OMe}$ & $\mathrm{H}$ & $\mathbf{9 2}$ \\
$\mathbf{9 0}$ & $\mathrm{H}$ & $\mathrm{OMe}$ & $\mathrm{H}$ & $\mathrm{OMe}$ & $\mathrm{OMe}$ & $\mathbf{5 1}$ \\
$\mathbf{9 1}$ & $\mathrm{OMe}$ & $\mathrm{H}$ & $\mathrm{H}$ & $\mathrm{OMe}$ & $\mathrm{OMe}$ & $\mathbf{5 9}$ \\
\hline
\end{tabular}

\section{Chemical reactions with 1,4-phenanthrenequinones}

\section{Synthesis of denbinobine (3) and isocypripedine (97)}

A 1,4-phenanthrenequinone named denbinobine was isolated by Talapatra et al. ${ }^{21}$ from 
Dendrobium nobile Lindl. Structure 3 was assigned to the natural product, but the position of the methoxy group at C-3 was merely based on the assumption that the molecule is of acetogenin origin. However, as recently pointed out by Thomson, ${ }^{4}$ phenylalanine is incorporated into two rings of the very common oxygenated phenanthrenes in orchids such as hircinol.

In the synthesis of 3, we started from the 9,10-dihydro 1,4-phenanthrenequinone $\mathbf{8 0}$ which could be dehydrogenated with palladium/charcoal to $\mathbf{6 0}$ in $95 \%$ yield. The crucial step was the selective demethylation of the trimethyl ethers 80 and $\mathbf{6 0}$ that could be effected by treatment with one equivalent of trimethlysilyl iodide ${ }^{55}$ to afford 94 and 3 in 72 and $62 \%$ yields, respectively. This remarkable selectivity in the cleavage of the sterically hindered methyl ether even in preference of the vinylogous ester (OMe at C-3) is a characteristic feature of the angular arrangement of 1,4-phenanthrenequinones.
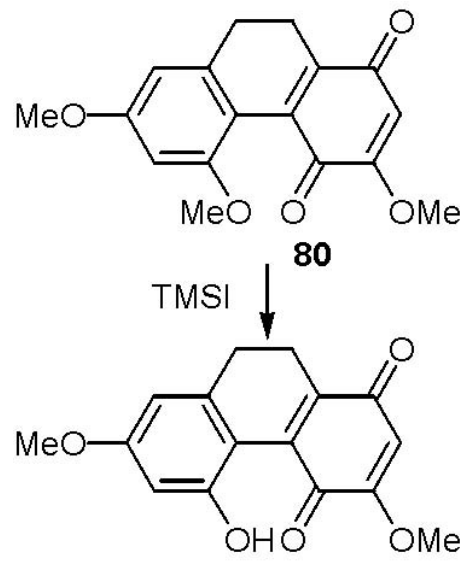

94

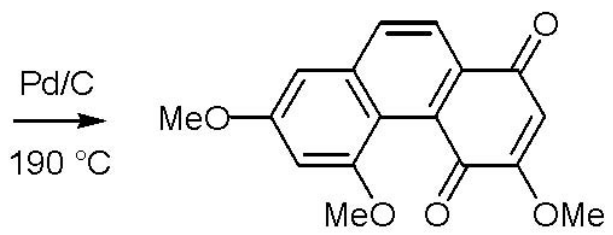

60

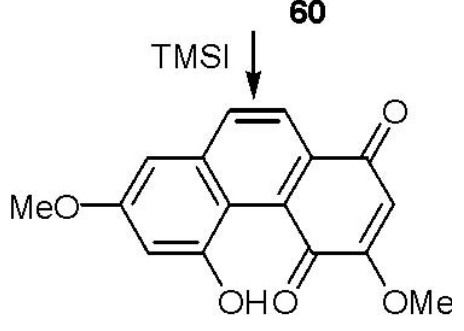

denbinobine (3)

Scheme 3. Synthesis of denbinobine (3) by dehydrogenation of $\mathbf{8 0}$ and selective demethylation of $\mathbf{6 0}$

Structure 3 was confirmed by X-ray structure determination and Fig. 2 shows the ORTEPplot with numbering scheme and bond distances (e. s. d.'s are $0.001 \AA$ for C- and O-atoms, and $0.01 \AA$ for $\mathrm{H}$-atoms). The smaller hydroxy group at $\mathrm{C}-5$ causes less twisting of the molecule as compared to similar 5-methoxy compounds 60 and $65 .{ }^{51}$

Comparison of the data of $\mathbf{3}$ with published values for the natural product ${ }^{21}$ shows identity of the melting point $\left(21{ }^{\circ} \mathrm{C}\right)$ and good agreement of the ${ }^{1} \mathrm{H}$-NMR spectra and the 
fragmentation pattern in the mass spectrum. However, deviations are seen in the intensities of the peaks of the mass spectrum. Unfortunately, no sample of the natural product was available for direct comparison with 3. 1,4-Phenanthrenequinones could not be extracted from Dentrobium nobile cultivated at various places in Europe.

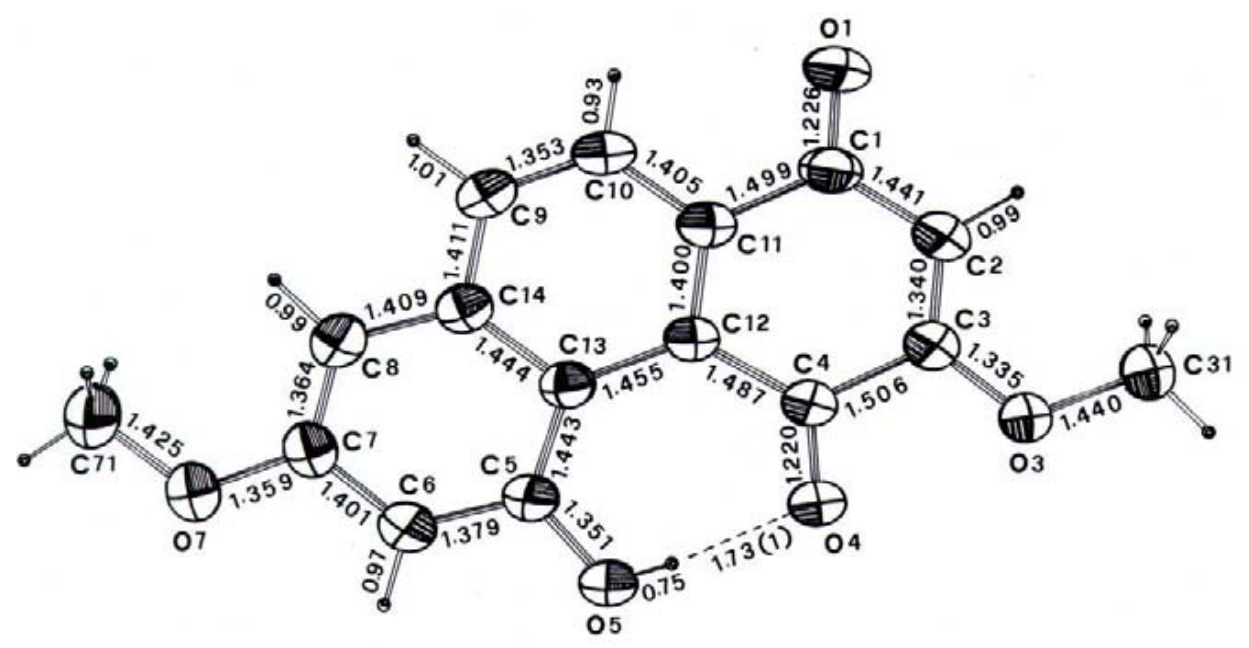

Figure 2. ORTEP-Plot of denbinobin (3) with numbering scheme and bond distances ( $\AA$ )

\section{The Thiele-Winter reaction}

In the Diels-Alder reaction of styrenes with methoxybenzoquinone (38), only traces of the corresponding 2-methoxy-1,4-phenanthrenequinones could be isolated. We have investigated the possibility to prepare these compounds in connection with a synthesis of cypripedine by introducing an additional oxygen atom at $\mathrm{C}-2$ and/or C-3 into the quinone part using the Thiele-Winter reaction. ${ }^{56,57}$ The 1,4-phenanthrenequinones 41, 55, and 56 were treated with acetic anhydride and catalytic amounts of perchloric acid. The benzyl ether was cleaved under these acidic conditions. The triacetoxylated phenanthrenes resulting from the Thiele-Winter reaction were not isolated but directly subjected to saponification, air oxidation, diazomethane treatment and chromatographic separation to afford the 1,4-phenanthrenequinones $\mathbf{1}, \mathbf{4 1}, \mathbf{5 9}$, 64 and 95-99 (general procedure VI). The first four products 1, 41, 59, and 64 could be identified by comparison with the previously prepared Diels-Alder adducts (see above). The C-3 methoxylated products $1,64,96$, and 97 were formed with a slight preference over their C-2 counterparts 41, 59, and 95 thus complementing the regiochemical outcome of the Diels- 
Alder reaction of styrenes with methoxybenzoquinone 39 (yields and m. p. see Scheme 4).

In an attempt to synthesize cypripedine (2) by selective methylation, the three saponified Thiele-Winter products, resulting from the benzyl ether 56, were treated with equivalent amounts of diazomethane to yield the monophenol $\mathbf{9 7}$ in addition to an inseparable mixture of the hydroxy-1,4-phenanthrenequinones 98 and 99. Structure 97 is isomeric (OMe on C-3 instead of C-2) to cypripedine (2). For structural proof, the inseparable mixture of phenols 98 and 99 were methylated and identified as the separable trimethoxy-1,4-phenanthrenequinones 59 and 64.

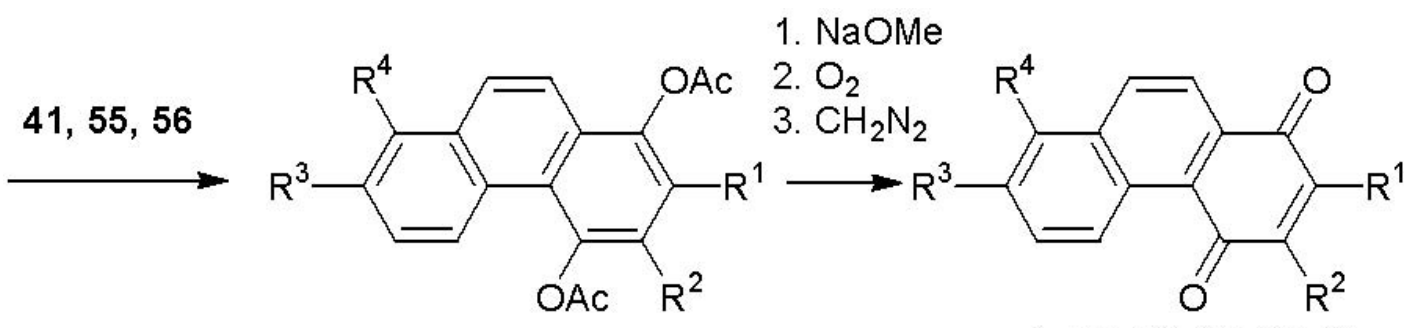

$1,41,59,64,95-99$

Scheme 4. Thiele-Winter reaction of 1,4-phenanthrenequinones 41, 55, 56 to afford the 2- and 3-methoxy-1,4-phenanthrenequinones 1, 41, 59, 64, 95-99

\begin{tabular}{|c|c|c|c|c|c|c|}
\hline$P Q$ & $\mathrm{R}^{1}$ & $\mathrm{R}^{2}$ & $\mathrm{R}^{3}$ & $\mathrm{R}^{4}$ & Yield [\%] & m.p. $\left[{ }^{\circ} \mathrm{C}\right]$ \\
\hline 41 & $\mathrm{OMe}$ & $\mathrm{H}$ & $\mathrm{H}$ & $\mathrm{H}$ & 31 & 135 \\
\hline 1 & $\mathrm{H}$ & $\mathrm{OMe}$ & $\mathrm{H}$ & $\mathrm{H}$ & 38 & 138 \\
\hline 59 & $\mathrm{OMe}$ & $\mathrm{H}$ & $\mathrm{OMe}$ & $\mathrm{OMe}$ & 11 & 166 \\
\hline 64 & $\mathrm{H}$ & $\mathrm{OMe}$ & $\mathrm{OMe}$ & $\mathrm{OMe}$ & 18 & 227 \\
\hline 95 & $\mathrm{OMe}$ & $\mathrm{H}$ & $\mathrm{OMe}$ & $\mathrm{OH}$ & 9 & 249 \\
\hline 96 & $\mathrm{H}$ & $\mathrm{OMe}$ & $\mathrm{OMe}$ & $\mathrm{OH}$ & 1 & 286 \\
\hline 97 & $\mathrm{H}$ & $\mathrm{OMe}$ & $\mathrm{OH}$ & $\mathrm{OMe}$ & 9 & 251 \\
\hline 98 & $\mathrm{OH}$ & $\mathrm{H}$ & $\mathrm{OMe}$ & $\mathrm{OMe}$ & 7 & 262 \\
\hline 99 & & $\mathrm{H}$ & $\mathrm{OH}$ & & $\mathrm{DMe}$ & $\mathrm{OMe}$ \\
\hline
\end{tabular}

Finally, the reactivity of the quinoid double bond of 1,4-phenanthrenequinones was 
studied in hydroxylation and epoxidation reactions. The cis-dihydroxylation of 7,8dimethoxy-1,4-phenanthrenequinone 54 proceeded smoothly upon treatment with catalytic amounts of osmium tetroxide and sodium perchlorate to give the diol $\mathbf{1 0 3}$ that was also characterized as acetonide 104. Epoxidation with hydrogen peroxide in basic solution converted 46, 54, and 67 in good yield into the epoxides 100-102 (general procedure VII). Therefor, in the epoxidation ${ }^{58}$ and cis-dihydroxylation ${ }^{59}$ reactions, the 1,4phenanthrenequinones show similar reactivity to the 1,4-naphthoquinones and 1,4benzoquinones.

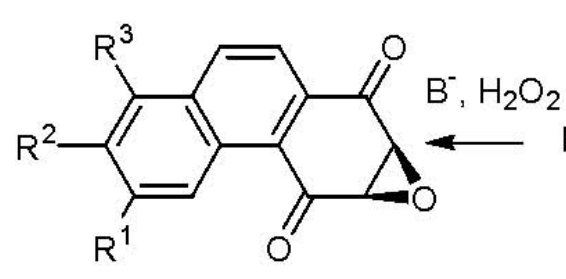

100-102

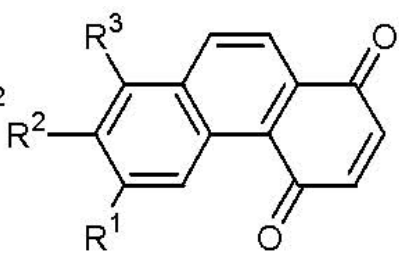

$46,54,67$

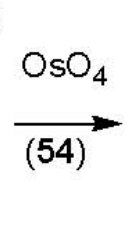

(54)

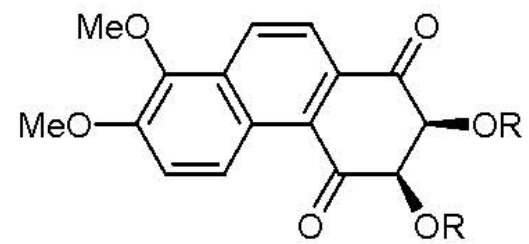

103: $\mathrm{R}=\mathrm{H}$;

104: $\mathrm{R}=\mathrm{CHMe}_{2}$

Scheme 5. Epoxidation and cis-hydroxylation of the 1,4-phenanthrenequinones 46, 54, and $\mathbf{7 4}$

\begin{tabular}{cccccc} 
PQE & $\mathrm{R}^{1}$ & $\mathrm{R}^{2}$ & $\mathrm{R}^{3}$ & Yield [\%] & m.p. $\left[{ }^{\circ} \mathrm{C}\right]$ \\
\hline $\mathbf{1 0 0}$ & $\mathrm{H}$ & $\mathrm{H}$ & $\mathrm{OMe}$ & 79 & 218 \\
$\mathbf{1 0 1}$ & $\mathrm{H}$ & $\mathrm{OMe}$ & $\mathrm{OMe}$ & 81 & 165 \\
$\mathbf{1 0 2}$ & $\mathrm{OMe}$ & $\mathrm{OMe}$ & $\mathrm{OMe}$ & 60 & 133 \\
\hline
\end{tabular}

\section{Electrochemistry}

Cyclic voltammograms of ten different 1,4-phenanthrenequinones (1, 41-46, 54, 64, 70, 74) were measured to determine redox potentials for possible correlation with their allergenic and sensitizing properties. ${ }^{28}$ The voltammetric measurements were performed in highly purified acetonitrile ${ }^{60}$ under rigorous exclusion of water. ${ }^{61}$ Under these conditions, the resulting anions and most dianions are quite persistent. Figure 3 shows the cyclic voltammogram of $\mathbf{4 5}$ with two successive one-electron transfers. The electrochemical data determined with a home-built computer-controlled apparatus are collected in Table 3 (for definition of values see legend of Figure 3). 
It is interesting to observe that methoxy-substitution on the distant ring $\mathrm{C}$ (positions $5-8$, 41, 44-46, 54) of the 1,4-phenanthrenequinones has only a small influence on the redox potential compared to the parent 1,4-phenanthrenequinone 41. Not surprisingly, direct methoxy substitution on the quinoid double bond as in 1, 64, 70, and 74 increases the absolute value of the potential by $108-143 \mathrm{mV}$. A remarkable deviation is seen in the potential of the sterically hindered 5-methoxy compound 43 in which the value is increased by $-118 \mathrm{mV}$ approaching the value of naphthoquinone $(-1018 \mathrm{mV})$. We rationalize this behavior by the twisted conformation of the $\mathbf{4 3}$ resulting in decreased conjugation of the quinoide part of the molecule with ring $\mathrm{C}$.

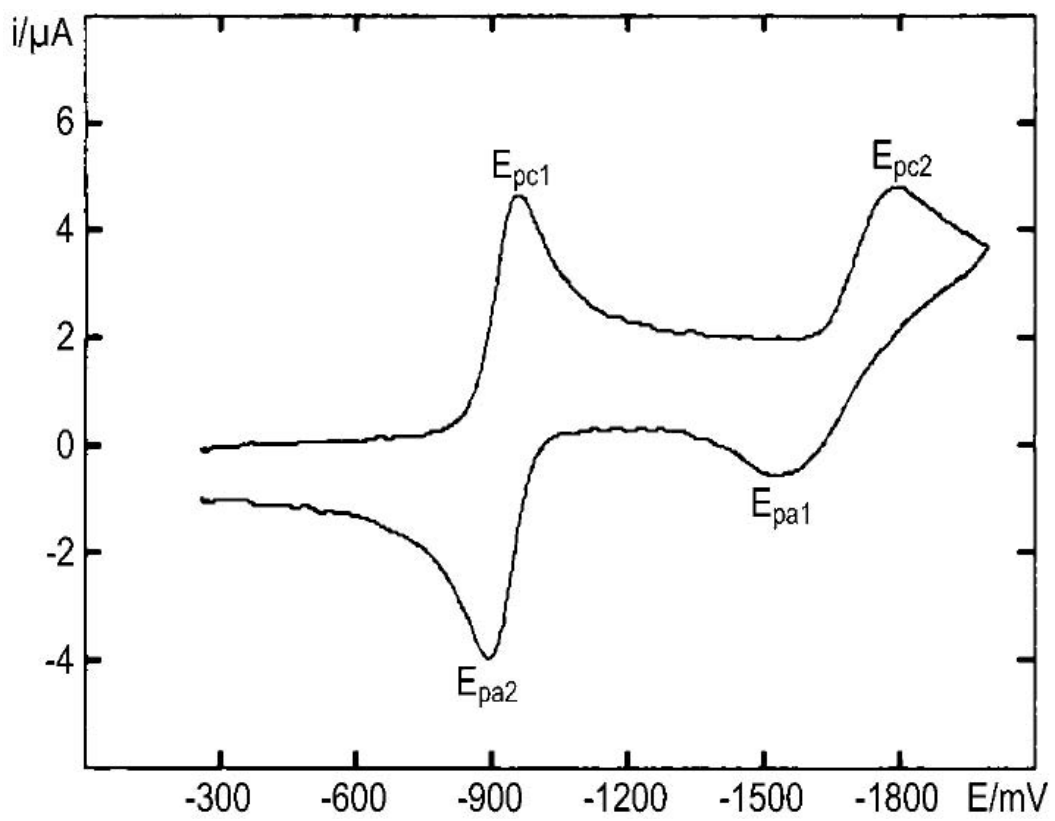

Figure 3. Cyclic voltammogram for 45 with two successive one-electron transfers. ( $\mathrm{E}_{\mathrm{pc} 1}$ : cathodic peak potential 1. ET, $\mathrm{E}_{\mathrm{pc} 2}$ : cathodic peak potential 2. ET, $\mathrm{E}_{\mathrm{pa} 1}$ : anodic peak potential 1. ET, $\mathrm{E}_{\mathrm{pa} 2}$ : anodic peak potential 2. ET); ET = electron transfer 
Table 3. Electrochemical data of the 1,4-phenanthrenequinones

\begin{tabular}{ccccccccccc}
\hline & $\mathbf{1}$ & $\mathbf{4 1}$ & $\mathbf{4 3}$ & $\mathbf{4 4}$ & $\mathbf{4 5}$ & $\mathbf{4 6}$ & $\mathbf{5 4}$ & $\mathbf{6 4}$ & $\mathbf{7 0}$ & $\mathbf{7 4}$ \\
\hline $\mathrm{E}_{\mathrm{pc} 1}$ & -1050 & -940 & -1058 & -956 & -956 & -940 & -934 & -1048 & -1073 & -1083 \\
$\mathrm{E}_{\mathrm{pc} 2}$ & -1942 & -1821 & -1850 & -1884 & -1799 & -1675 & -1783 & -1934 & -1877 & -1917 \\
$\Delta \mathrm{E}_{\mathrm{p} 1}=\mathrm{Epa1}-\mathrm{Epc1}$ & 80 & 56 & 82 & 75 & 67 & 63 & 63 & 64 & 76 & 76 \\
$\mathrm{i}_{\mathrm{pa} 1} / \mathrm{i}_{\mathrm{pc} 1}$ & 0.84 & 8.86 & 0.82 & 0.79 & 0.84 & 0.89 & 0.81 & 0.87 & 0.88 & 0.81 \\
\hline
\end{tabular}

Finally, we have investigated the redox potential of 1,4-phenanthrenequinone 41 with respect to the other mono- bi- and tricyclic quinones benzoquinone (105), 1,4-napthoquinone (106, 9,10-phenanthrenequinone 107 and 9,10-anthraquinone 108. In Figure 4, the redox potential $\mathrm{E}_{\mathrm{pc}}{ }^{62}$ of the quinones is correlated with their LUMO energies (absolute values). A relatively linear correlation is observed.

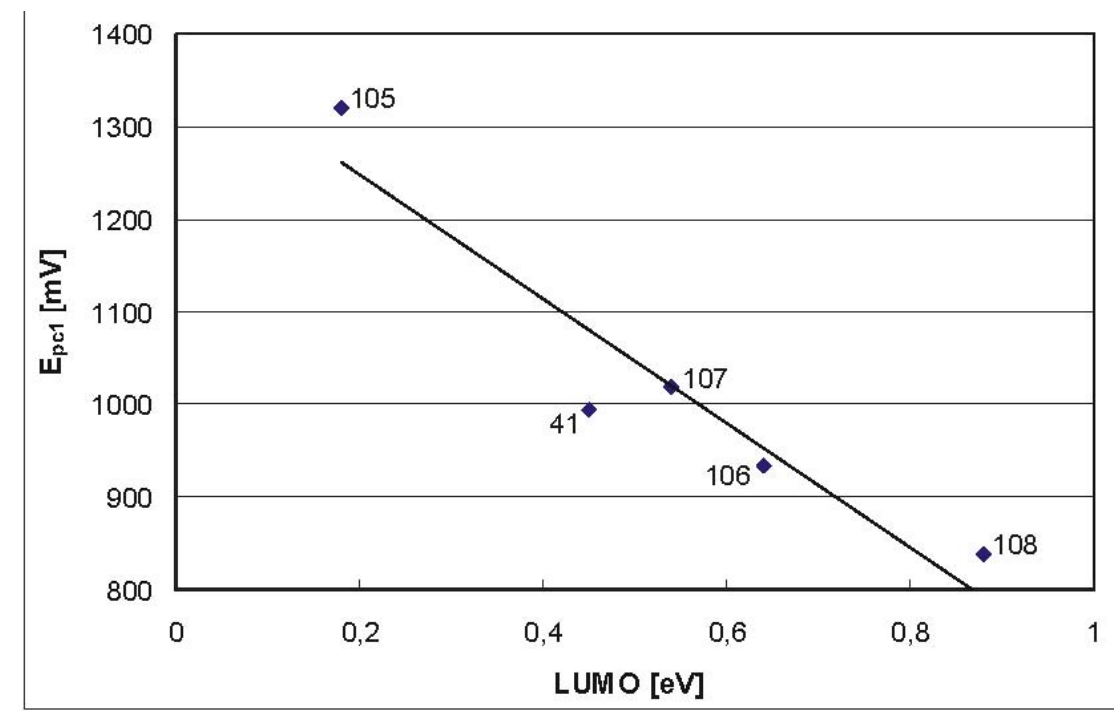<smiles>O=C1C=CC(=O)C=C1</smiles>

105<smiles>O=C1C=CC(=O)c2ccccc21</smiles>

106

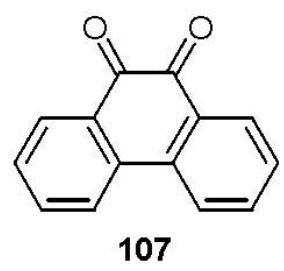

107<smiles>O=C1c2ccccc2C(=O)c2ccccc21</smiles>

108

Figure 4. Redox potential $\mathrm{E}_{\mathrm{pc}}$ of the quinones 41, 105, 106, 107, and 108 correlated with their LUMO energy (absolute values) 


\section{Experimental Section}

Crystal data for denbinobin. $\mathrm{C}_{16} \mathrm{H}_{12} \mathrm{O}_{5}, \mathrm{M}_{\mathrm{r}}=284.27$, triclinic, space group $\mathrm{P}-1^{-}$with unit cell dimensions $\mathrm{a}=8.560(1), \mathrm{b}=8.657(1), \mathrm{c}=9.184(1) \AA, \alpha=110.04(1), \beta=94.47(1), \gamma=$ 98.14(1) $)^{\circ}, \mathrm{V}=631.0(3) \AA^{3}, \mathrm{Z}=2, \mathrm{D}_{\mathrm{x}}=1.496 \mathrm{Mg} \mathrm{m}^{-3}, \mathrm{Cu}-\mathrm{K}_{\alpha}$ radiation, $\lambda=1.5418 \AA, \mu=$ $0.899 \mathrm{~mm}^{-1}, \mathrm{~F}(000)=296, \mathrm{~T}=296 \mathrm{~K}$, final $\mathrm{R}=0.050$ for 2292 observed reflections.

\section{Experimental part of the $\mathrm{X}$-ray structure determination}

Small amounts of denbinobin were recrystallized from dichloromethane. A dark-red plate shaped crystal with dimensions $0.25 \times 0.24 \times 0.65 \mathrm{~mm}$ was used for the measurements. Cell parameters were obtained by least-squares refinement from the angular settings of 25 reflections in the range $25^{\circ}<\theta<76^{\circ}$. Enraf-Nonius CAD-4 diffractometer with graphite monochromatized $\mathrm{CuK}_{\alpha}$ radiation was applied. The intensities of 2850 reflections with $2^{\circ}<\theta<75^{\circ}(-10 \leq \mathrm{h} \leq 0,-10 \leq \mathrm{k} \leq 10,-11 \leq 1 \leq 11)$ were measured on the diffractometer by the $\theta-2 \theta$ scan technique at a variable scan rate $0.3^{\circ}$ to $20^{\circ} \mathrm{min}^{-1} .2292$ unique reflections were observed above background with I>3 $\sigma$ (I), $\sigma$ (I) based on counting statistics; 288 reflections were unobserved by this criterion.

Data reduction, Lorentz-polarization correction, absorption correction ( $\psi$-scan technique), solution, and refinement of the structure were carried out with the CAD-4 structure determination package. ${ }^{63}$ A superstructure effect was observed in the normalized structure factors of the eight parity groups: reflections with $1=2 \mathrm{n}$ showed values of about 1.20 , those with $1=2 \mathrm{n}+1$ only of about 0.65 . In addition, hypercentricity was noticed in the data statistics. For this reason the structure had to be solved in the space group $\mathrm{P} 1$, in combination of MULTAN82 and Fourier calculations. The centre of symmetry was determined by two similar molecular fragments. The psotional and anisotropic temperature parameters of the $\mathrm{C}$ and $\mathrm{O}$ atoms were refined with unit weight. All $\mathrm{H}$ atoms were localized in the subsequent difference Fourier map. In the final cycle of full matrix least-squares refinement positional parameters of all atoms and anisotropic temperature factor coefficients for the $\mathrm{C}$ and $\mathrm{O}$ atoms were varied. The temperature parameters of the $\mathrm{H}$ atoms were refined isotropically. The final R was 4.96 \%, 238 parameter refined, number of reflections 2292 . The max. height in the final difference Fourier synthesis was $0.27 \mathrm{eA}^{-3}$. Tables of thermal parameters, bond distances and angles have been deposited. ${ }^{64}$ 
3-Acetyloxy-2-methoxybenzaldehyde (22). A solution of 3-acetyloxy-2hydroxybenzaldehyd $(2.50 \mathrm{~g}, 14 \mathrm{mmol})$ in methyl iodide $(50 \mathrm{~mL})$ was treated under nitrogen with $\mathrm{Ag}_{2} \mathrm{O}$ (9.30 g). The suspension was stirred for $4 \mathrm{~h}$ (TLC monitoring), filtered, the filtrate evaporated under reduced pressure, and the residue purified by flash chromatography on silica gel (dichloromethane) to yield $22(2.21 \mathrm{~g})(81 \%) ; \mathrm{mp} 55{ }^{\circ} \mathrm{C} . \mathrm{IR}\left(\mathrm{CCl}_{4}\right): v=1780 \mathrm{~cm}^{-1}$ (Ac), $1700(\mathrm{C}=\mathrm{O}), 1480,1255,1195 ; \mathrm{UV}: \lambda_{\max }(\lg \varepsilon)=212 \mathrm{~nm}(4.126), 250(3.883), 301(3.264) ;{ }^{1} \mathrm{H}$ NMR (400 MHz): $\delta=2.38\left(\mathrm{~s}, 3 \mathrm{H}, \mathrm{CH}_{3}\right), 3.96\left(\mathrm{~s}, 3 \mathrm{H}, \mathrm{OCH}_{3}\right), 7.22\left(\mathrm{dd}, J_{4,5}=8 \mathrm{~Hz}, J_{5,6}=8\right.$ $\mathrm{Hz}, 1 \mathrm{H}, 5-\mathrm{H}), 7.34\left(\mathrm{dd}, J_{4,5}=8 \mathrm{~Hz}, J_{4,6}=2 \mathrm{~Hz}, 1 \mathrm{H}, 4-\mathrm{H}\right), 7.74\left(\mathrm{dd}, J_{5,6}=8 \mathrm{~Hz}, J_{4,6}=2 \mathrm{~Hz}\right.$, 1H, 6-H), 10.38 (s, 1H, CHO); Ms: m/z (\%) = $194\left(9, \mathrm{M}^{+}\right), 152$ (100), $137(24), 134$ (24), 109 (20), 106 (32). Anal. Calcd for $\mathrm{C}_{10} \mathrm{H}_{10} \mathrm{O}_{4}$ : C, 61.85; H, 5.19. Found: C, 61.56; H, 5.29.

\section{General procedure 1. Benzylation of phenols}

To a solution of $\mathrm{NaOH}(416 \mathrm{mg}, 1.0 \mathrm{mmol})$ in $(7.4 \mathrm{~mL})$ was added the phenolic benzaldehyde (6.6 mmol) in dimethyl sulfoxide $(2 \mathrm{~mL})$ and benzyl chloride $(1.2 \mathrm{~mL}, 10.4 \mathrm{mmol})$. The mixture was stirred for $4-8 \mathrm{~h}$ at $20^{\circ} \mathrm{C}$ under nitrogen (TLC monitoring) and then quenched by addition of ice-water. The mixture was extracted with diethyl ether $(50 \mathrm{~mL})$, the organic phase washed three times with water $(50 \mathrm{~mL})$, dried $\left(\mathrm{Na}_{2} \mathrm{SO}_{4}\right)$, and concentrated at reduced pressure. The residue was purified by column chromatography on silica gel to afford the respective benzyl ethers.

2-Benzyloxy-3-methoxybenzaldehyde (19). According to procedure I, 2-hydroxy-3methoxybenzaldehyde (1.00 g, $6.6 \mathrm{mmol})$ was converted to 19; yield: $1.51 \mathrm{~g}(95 \%)$; $\mathrm{mp} 45^{\circ} \mathrm{C}$ $\left(\right.$ ref. $\left.^{43}: 45^{\circ} \mathrm{C}\right) .{ }^{1} \mathrm{H}$ NMR $(400 \mathrm{MHz}): \delta=3.91\left(\mathrm{~s}, 3 \mathrm{H}, \mathrm{OCH}_{3}\right), 5.16\left(\mathrm{~s}, 2 \mathrm{H}, \mathrm{CH}_{2}\right), 7.18\left(\mathrm{~m}_{\mathrm{c}}, 3 \mathrm{H}\right.$, Ar-H), $7.34\left(\mathrm{~m}_{\mathrm{c}}, 5 \mathrm{H}, \mathrm{C}_{6} \mathrm{H}_{5}\right), 10.22$ (s, 1H, CHO).

3-Benzyloxy-2-methoxybenzaldehyde (20). According to procedure I, 3-Acetoxy-2methoxybenzaldehyde $(1.28 \mathrm{~g}, 6.6 \mathrm{mmol})$ was benzylated to give 20 , yield $1.459 \mathrm{~g}(91 \%)$. IR: $v=1695 \mathrm{~cm}^{-1}(\mathrm{C}=\mathrm{O}), 1585,1275,1250,1225,1005 ; \mathrm{UV}: \max (\lg )=214 \mathrm{~nm}$ (4.478), 254 (4.038), 320 (3.640); ${ }^{1} \mathrm{H} \mathrm{NMR}(300 \mathrm{MHz}): \delta=4.03$ (s, 3H, $\left.\mathrm{OCH}_{3}\right), 5.16\left(\mathrm{~s}, 2 \mathrm{H}, \mathrm{CH}_{2}\right), 7.10$ $\left(\mathrm{m}_{\mathrm{c}}, 1 \mathrm{H}, 5-\mathrm{H}\right), 7.20\left(\mathrm{dd}, J_{4,5}=8 \mathrm{~Hz}, 1 \mathrm{H}, 4-\mathrm{H}\right), 7.41\left(\mathrm{~m}_{\mathrm{c}}, 6 \mathrm{H}, 6-\mathrm{H}, \mathrm{C}_{6} \mathrm{H}_{5}\right), 10.45$ (s, 1H, CHO); $\operatorname{MS}\left(30^{\circ} \mathrm{C}\right): m / z(\%)=242\left(11, \mathrm{M}^{+}\right), 92(8), 91(100), 65$ (11). Anal. Calcd for $\mathrm{C}_{15} \mathrm{H}_{14} \mathrm{O}_{3}$ : $\mathrm{C}$, 74.36; H, 5.82. Found: C, 74.20; H, 5.59. 
3-Benzyloxy-4-methoxybenzaldehyde (21). According to procedure I, 3-Hydroxy-4methoxybenzaldehyde $(1.00 \mathrm{~g}, 6.6 \mathrm{mmol})$ was converted to 21 ; yield: $1.50 \mathrm{~g}(94 \%) .{ }^{1} \mathrm{H} \mathrm{NMR}$ $(300 \mathrm{MHz}): \delta=3.97\left(\mathrm{~s}, 3 \mathrm{H}, \mathrm{OCH}_{3}\right), 5.20\left(\mathrm{~s}, 2 \mathrm{H}, \mathrm{CH}_{2}\right), 7.00(\mathrm{~d}, J=8 \mathrm{~Hz}, 1 \mathrm{H}, 5-\mathrm{H}), 7.32$ $7.49\left(\mathrm{~m}, 7 \mathrm{H}, 2-\mathrm{H}, 6-\mathrm{H}, \mathrm{C}_{6} \mathrm{H}_{5}\right)$.

\section{General procedure 2. Synthesis of styrols by Wittig reaction}

A solution of the benzaldehyde $(10 \mathrm{mmol})$, methyltriphenylphosphonium bromide $(4.286 \mathrm{~g}$, $12 \mathrm{mmol}), \mathrm{K}_{2} \mathrm{CO}_{3}(6.63 \mathrm{~g}, 48 \mathrm{mmol})$ and 18-crown-6 (30 mg) in dry THF (30 mL) was stirred under nitrogen at $60{ }^{\circ} \mathrm{C}$ (3-6 h, TLC monitoring). ${ }^{42}$ The solvent was removed under reduced pressure and the residue was purified by column chromatography on silica gel (petroleum ether) to afford the styrols. Known stryrols are only characterized by their ${ }^{1} \mathrm{H}$ NMR spectra.

2-Benzyloxy-3-methoxystyrol (35). Yield: $2.367 \mathrm{~g}$ (98\%). ${ }^{1} \mathrm{H}$ NMR (300 MHz): $\delta=3.87$ (s, $\left.3 \mathrm{H}, \mathrm{OCH}_{3}\right), 4.97\left(\mathrm{~s}, 2 \mathrm{H}, \mathrm{CH}_{2}\right), 5.24\left(\mathrm{dd}, J_{\text {cis }}=11 \mathrm{~Hz}, J_{\text {gem }}=1 \mathrm{~Hz}, 1 \mathrm{H}, \beta-\mathrm{H}\right), 5.72\left(\mathrm{dd}, J_{\text {trans }}=\right.$ $\left.18 \mathrm{~Hz}, J_{\text {gem }}=1 \mathrm{~Hz}, 1 \mathrm{H}, \alpha-\mathrm{H}\right), 6.85\left(\mathrm{dd}, J_{4,5}=8 \mathrm{~Hz}, J_{4,6}=1 \mathrm{~Hz}, 1 \mathrm{H}, 4-\mathrm{H}\right), 7.08\left(\mathrm{~m}_{\mathrm{c}}, 2 \mathrm{H}, 5-\mathrm{H}\right.$, à-H), $7.30\left(\mathrm{~m}_{\mathrm{c}}, 5 \mathrm{H}, \mathrm{C}_{6} \mathrm{H}_{5}\right), 7.48\left(\mathrm{dd}, J_{5,6}=8 \mathrm{~Hz}, J_{4,6}=1 \mathrm{~Hz}, 1 \mathrm{H}, 6-\mathrm{H}\right)$.

3-Benzyloxy-2-methoxystyrol (36). Yield: $2.423 \mathrm{~g}(10 \mathrm{mmol})$. IR: $v=1580 \mathrm{~cm}^{-1}(\mathrm{C}=\mathrm{C})$, 1475, 1405, 1275, 1010; UV: $\max (\lg )=221 \mathrm{~nm}$ (4.507), 251 (4.033), 295 (3.240); ${ }^{1} \mathrm{H} \mathrm{NMR}$ (400 MHz): $\delta=3.85\left(\mathrm{~s}, 3 \mathrm{H}, \mathrm{OCH}_{3}\right), 5.12\left(\mathrm{~s}, 2 \mathrm{H}, \mathrm{CH}_{2}\right), 5.30\left(\mathrm{dd}, J_{\text {cis }}=11 \mathrm{~Hz}, J_{\text {gem }}=1 \mathrm{~Hz}, 1 \mathrm{H}\right.$, $\beta-\mathrm{H}), 5.76\left(\mathrm{dd}, J_{\text {trans }}=18 \mathrm{~Hz}, J_{\text {gem }}=1 \mathrm{~Hz}, 1 \mathrm{H}, \alpha-\mathrm{H}\right), 6.87\left(\mathrm{dd}, J_{4,5}=8 \mathrm{~Hz}, J_{4,6}=1 \mathrm{~Hz}, 1 \mathrm{H}, 4-\right.$ $\mathrm{H}), 6.98\left(\mathrm{dd}, J_{4,5}=8 \mathrm{~Hz}, J_{5,6}=8 \mathrm{~Hz}, 1 \mathrm{H}, 5-\mathrm{H}\right), 7.04\left(\mathrm{dd}, J_{\text {cis }}=11 \mathrm{~Hz}, J_{\text {trans }}=18 \mathrm{~Hz}, 1 \mathrm{H}\right.$ à-H), $7.13\left(\mathrm{dd}, J_{5,6}=8 \mathrm{~Hz}, J_{4,6}=1 \mathrm{~Hz}, 1 \mathrm{H}, 6-\mathrm{H}\right), 7.39\left(\mathrm{~m}_{\mathrm{c}}, 5 \mathrm{H}, \mathrm{C}_{6} \mathrm{H}_{5}\right) ; \mathrm{Ms}: m / z(\%)=240\left(2, \mathrm{M}^{+}\right)$, 121 (7), 91 (100), 78 (20), 65 (31), 51 (23). Anal. Calcd for $\mathrm{C}_{16} \mathrm{H}_{16} \mathrm{O}_{2}:$ C, 79.97; H, 6.71. Found: C, 80.10; H, 6.84.

3-Benzyloxy-4-methoxystyrol (37). Yield: $2.282 \mathrm{~g}(95 \%) .{ }^{1} \mathrm{H}$ NMR (400 MHz): $\delta=3.83$ (s, $\left.3 \mathrm{H}, \mathrm{OCH}_{3}\right), 5.06\left(\mathrm{dd}, J_{\mathrm{cis}}=11 \mathrm{~Hz}, J_{\mathrm{gem}}=1 \mathrm{~Hz}, 1 \mathrm{H}, \beta-\mathrm{H}\right), 5.11\left(\mathrm{~s}, 2 \mathrm{H}, \mathrm{CH}_{2}\right), 5.48\left(\mathrm{dd}, J_{\text {trans }}=\right.$ $\left.18 \mathrm{~Hz}, J_{\text {gem }}=1 \mathrm{~Hz}, 1 \mathrm{H}, \beta-\mathrm{H}\right), 6.60\left(\mathrm{dd}, J_{\text {cis }}=11 \mathrm{~Hz}, J_{\text {trans }}=18 \mathrm{~Hz}, 1 \mathrm{H}, \alpha-\mathrm{H}\right), 6.84(\mathrm{~d}, J=9$ $\mathrm{Hz}, 1 \mathrm{H}, 5-\mathrm{H}), 6.95\left(\mathrm{dd}, J_{5,6}=9 \mathrm{~Hz}, J_{2,6}=3 \mathrm{~Hz}, 1 \mathrm{H}, 6-\mathrm{H}\right), 7.00$ (d, J = $\left.3 \mathrm{~Hz}, 1 \mathrm{H}, 2-\mathrm{H}\right), 7.37$ $\left(\mathrm{m}_{\mathrm{c}}, 5 \mathrm{H}, \mathrm{C}_{6} \mathrm{H}_{5}\right)$.

2,4-Dimethoxystyrol (28). Yield: $1.512 \mathrm{~g}(92 \%) .{ }^{1} \mathrm{H}$ NMR (400 MHz): $\delta=3.75(\mathrm{~s}, 3 \mathrm{H}$, 
$\left.\mathrm{OCH}_{3}\right), 3.76\left(\mathrm{~s}, 3 \mathrm{H}, \mathrm{OCH}_{3}\right), 5.09\left(\mathrm{dd}, J_{\text {cis }}=11 \mathrm{~Hz}, J_{\text {gem }}=2 \mathrm{~Hz}, 1 \mathrm{H}, \beta-\mathrm{H}\right), 5.58\left(\mathrm{dd}, J_{\text {trans }}=18\right.$ $\left.\mathrm{Hz}, J_{\text {gem }}=2 \mathrm{~Hz}, 1 \mathrm{H}, \beta-\mathrm{H}\right), 6.39(\mathrm{~d}, J=2 \mathrm{~Hz}, 1 \mathrm{H}, 3-\mathrm{H}), 6.42\left(\mathrm{dd}, J_{5,6}=8 \mathrm{~Hz}, J_{3,5}=2 \mathrm{~Hz}, 1 \mathrm{H}\right.$, $5-\mathrm{H}), 6.92\left(\mathrm{dd}, J_{\text {cis }}=11 \mathrm{~Hz}, J_{\text {trans }}=18 \mathrm{~Hz}, 1 \mathrm{H}, \alpha-\mathrm{H}\right), 7.34(\mathrm{~d}, J=8 \mathrm{~Hz}, 1 \mathrm{H}, 6-\mathrm{H})$.

3,5-Dimethoxystyrol (31). Yield: 1.624 (99\%). ${ }^{1} \mathrm{H}$ NMR (400 MHz): $\delta=3.76$ (s, $6 \mathrm{H}, \mathrm{OCH}_{3}$ ), $5.23\left(\mathrm{dd}, J_{\text {cis }}=11 \mathrm{~Hz}, J_{\text {gem }}=1 \mathrm{~Hz}, 1 \mathrm{H}, \beta-\mathrm{H}\right), 5.71\left(\mathrm{dd}, J_{\text {trans }}=18 \mathrm{~Hz}, J_{\text {gem }}=1 \mathrm{~Hz}, 1 \mathrm{H}, \beta-\mathrm{H}\right)$, $6.37(\mathrm{~d}, J=2 \mathrm{~Hz}, 4-\mathrm{H}), 6.55(\mathrm{~d}, J=2 \mathrm{~Hz}, 2 \mathrm{H}, 2-\mathrm{H}, 6-\mathrm{H}), 6.62\left(\mathrm{dd}, J_{\text {cis }}=11 \mathrm{~Hz}, J_{\text {trans }}=18 \mathrm{~Hz}\right.$, $1 \mathrm{H},-\mathrm{H})$.

2,3,4-Trimethoxystyrol (32). Yield: $1.806 \mathrm{~g}(93 \%) .{ }^{1} \mathrm{H}$ NMR (400 MHz): $\delta=3.85$ (s, 3H, $\left.\mathrm{OCH}_{3}\right), 3.86\left(\mathrm{~s}, 3 \mathrm{H}, \mathrm{OCH}_{3}\right), 3.87\left(\mathrm{~s}, 3 \mathrm{H}, \mathrm{OCH}_{3}\right), 5.18\left(\mathrm{dd}, J_{\text {cis }}=11 \mathrm{~Hz}, J_{\text {gem }}=1 \mathrm{H}, \beta-\mathrm{H}\right), 5.64$ $\left(\mathrm{dd}, J_{\text {trans }}=18 \mathrm{~Hz}, J_{\text {gem }}=1 \mathrm{~Hz}, 1 \mathrm{H}, \beta-\mathrm{H}\right), 6.65(\mathrm{~d}, J=9 \mathrm{~Hz}, 1 \mathrm{H}, 5-\mathrm{H}), 6.92\left(\mathrm{dd}, J_{\text {cis }}=11 \mathrm{~Hz}\right.$, $\left.J_{\text {trans }}=18 \mathrm{~Hz}, \alpha-\mathrm{H}\right), 7.19(\mathrm{~d}, J=9 \mathrm{~Hz}, 1 \mathrm{H}, 6-\mathrm{H})$.

3,4,5-Trimethoxystyrol (34). Yield: $1.832 \mathrm{~g}(94 \%) .{ }^{1} \mathrm{H}$ NMR (400 MHz): $\delta=3.85$ (s, $3 \mathrm{H}$, $\left.\mathrm{OCH}_{3}\right), 3.87\left(\mathrm{~s}, 6 \mathrm{H}, \mathrm{OCH}_{3}\right), 5.21\left(\mathrm{dd}, J_{\mathrm{cis}}=11 \mathrm{~Hz}, J_{\mathrm{gem}}=1 \mathrm{~Hz}, 1 \mathrm{H}, \beta-\mathrm{H}\right), 5.65\left(\mathrm{dd}, J_{\text {trans }}=18\right.$ $\left.\mathrm{Hz}, J_{\mathrm{gem}}=1 \mathrm{~Hz}, 1 \mathrm{H}, \beta-\mathrm{H}\right), 6.63\left(\mathrm{dd}, J_{\mathrm{cis}}=11 \mathrm{~Hz}, J_{\text {trans }}=18 \mathrm{~Hz}, 1 \mathrm{H}, \alpha-\mathrm{H}\right), 6.63(\mathrm{~s}, 2 \mathrm{H}, 2-\mathrm{H}, 6-$ $\mathrm{H})$.

\section{General procedure 3. Synthesis of 1,4-phenanthenequinones by Diels-Alder reaction}

A solution of the styrene (3.4 mmol), 1,4-benzoquinone (17 mmol), 2-methoxy-1,4benzoquinone or 2,3-dimethoxy-1,4-benzoquinone (each $17 \mathrm{mmol}$ ) and trichloroacetic acid (34 mg) were heated to $100{ }^{\circ} \mathrm{C}$ in toluene for the times indicated in Table 1. The crude product was chromatographed on neutral alumina (dichloromethane). The solvent was removed under reduced pressure and the residue sublimed to remove the benzoquinone. The residue was chromatographed on silica gel $\left(\mathrm{CH}_{2} \mathrm{Cl}_{2}\right)$ and the pure fractions crystallized from petroleum ether. For yields, melting points and reaction times see Table 1.

1,4-Phenanthrenequinone (41). ${ }^{1} \mathrm{H}$ NMR: $\delta=6.94(\mathrm{~d}, J=10 \mathrm{~Hz}, 1 \mathrm{H}, 2-\mathrm{H}), 6.97$ (d, $J=10$ $\mathrm{Hz}, 1 \mathrm{H}, 3-\mathrm{H}$ ), 7.65 (ddd, $J_{7,8}=8 \mathrm{~Hz}, J_{6,7}=7 \mathrm{~Hz}, J_{5,7}=1 \mathrm{~Hz}, 1 \mathrm{H}, 7-\mathrm{H}$ ), 7.74 (ddd, $J_{5,6}=9 \mathrm{~Hz}$, $\left.J_{6,7}=7 \mathrm{~Hz}, J_{6,8}=2 \mathrm{~Hz}, 1 \mathrm{H}, 6-\mathrm{H}\right), 7.89\left(\mathrm{ddd}, J_{7,8}=8 \mathrm{~Hz}, J_{6,8}=2 \mathrm{~Hz}, J_{5,8}=1 \mathrm{~Hz}, 1 \mathrm{H}, 8-\mathrm{H}\right)$, $8.16(\mathrm{~d}, J=9 \mathrm{~Hz}, 1 \mathrm{H}, 10-\mathrm{H}), 8.17(\mathrm{~d}, J=9 \mathrm{~Hz}, 1 \mathrm{H}, 9-\mathrm{H}), 9.55$ (ddd, $J_{5,6}=9 \mathrm{~Hz}, J_{5,7}=1 \mathrm{~Hz}$, $\left.J_{5,8}=1 \mathrm{~Hz}, 1 \mathrm{H}, 5-\mathrm{H}\right) .{ }^{13} \mathrm{C}$ NMR: $\delta=121.78(\mathrm{C}-10), 127.08(\mathrm{C}-10 \mathrm{a}), 127.84(\mathrm{C}-5), 128.62(\mathrm{C}-$ 
8), 129.83 (C-8a), 130.04 (C-6), 130.73 (C-4b), 132.16 (C-4a), 135.04 (C-9), 135.73 (C-2), 140.42 (C-3), 185.63 (C-4), 187.94 (C-1).

6-Methoxy-1,4-phenanthrenequinone (44). IR: $v=1650 \mathrm{~cm}^{-1}(\mathrm{C}=0), 1615(\mathrm{C}=\mathrm{C}), 1590$, 1460, 1305, 1275, 1220, 1080, 840; UV: $\lambda_{\max }(\lg \varepsilon)=234 \mathrm{~nm}$ (4.606), 269 (4.144), $283 \mathrm{sh}$ (4.048), 372 (3.517), 450 (3.422); ${ }^{1} \mathrm{H}$ NMR (300 MHz): $\delta=4.03$ (s, $\left.3 \mathrm{H}, \mathrm{OCH}_{3}\right), 6.94$ (d, $J=$ $10 \mathrm{~Hz}, 1 \mathrm{H}, 2-\mathrm{H}), 6.97(\mathrm{~d}, J=10 \mathrm{~Hz}, 1 \mathrm{H}, 3-\mathrm{H}), 7.31\left(\mathrm{dd}, J_{7,8}=9 \mathrm{~Hz}, J_{5,7}=3 \mathrm{~Hz}, 1 \mathrm{H}, 7-\mathrm{H}\right)$, 7.80 (d, $J=9 \mathrm{~Hz}, 1 \mathrm{H}, 8-\mathrm{H}), 8.05$ (d, $J=8 \mathrm{~Hz}, 1 \mathrm{H}, 10-\mathrm{H}), 8.12$ (d, $J=8 \mathrm{~Hz}, 1 \mathrm{H}, 9-\mathrm{H}), 9.07$ (d, $J=3 \mathrm{~Hz}, 1 \mathrm{H}, 5-\mathrm{H}) ;{ }^{13} \mathrm{C}$ NMR: $\delta=55.53\left(\mathrm{OCH}_{3}\right), 105.59(\mathrm{C}-5), 119.88(\mathrm{C}-10), 121.66(\mathrm{C}-7)$, 125.35 (C-10a), 129.98 (C-8), 131.82 (C-8a), 132.43 (C-4b), 132.69 (C-4a), 134.72 (C-9), 135.68 (C-2), 140.58 (C-3), 161.46 (C-6), 185.83 (C-4), 188.07 (C-1).

7-Methoxy-1,4-phenanthrenequinone (45); 5-methoxy-1,4-phenanthrenequinone (43) and 9,10-dihydro-7-methoxy-1,4-phenanthrenequinone (76)

Data for 45. $\mathrm{Mp} 153^{\circ} \mathrm{C}\left(\mathrm{ref}^{29)}: 153^{\circ} \mathrm{C}\right)$. IR: $v=1650 \mathrm{~cm}^{-1}(\mathrm{C}=\mathrm{O}), 1610(\mathrm{C}=\mathrm{C}), 1240,1080$, 850; UV: $\lambda_{\max }(\lg \varepsilon)=233 \mathrm{~nm}$ (4.622), $250 \mathrm{sh}$ (4.265), 291 (4.010), 301 (4.106), 390 3.684); ${ }^{1} \mathrm{H}$ NMR $(250 \mathrm{MHz}): \delta=4.01\left(\mathrm{~s}, 3 \mathrm{H}, \mathrm{OCH}_{3}\right), 6.96(\mathrm{~d}, J=10 \mathrm{~Hz}, 1 \mathrm{H}, 2-\mathrm{H}), 6.97(\mathrm{~d}, J=10$ $\mathrm{Hz}, 1 \mathrm{H}, 3-\mathrm{H}), 7.21(\mathrm{~d}, J=3 \mathrm{~Hz}, 1 \mathrm{H}, 8-\mathrm{H}), 7.42\left(\mathrm{dd}, J_{5,6}=10 \mathrm{~Hz}, J_{6,8}=3 \mathrm{~Hz}, 1 \mathrm{H}, 6-\mathrm{H}\right), 8.08$ (d, $J=9 \mathrm{~Hz}, 1 \mathrm{H}, 10-\mathrm{H}), 8.17$ (d, $J=9 \mathrm{~Hz}, 1 \mathrm{H}, 9-\mathrm{H}), 9.50$ (d, $J=10 \mathrm{~Hz}, 1 \mathrm{H}, 5-\mathrm{H}) .{ }^{13} \mathrm{C}$ NMR: $\delta=55.39\left(\mathrm{OCH}_{3}\right), 106.62(\mathrm{C}-8), 122.63(\mathrm{C}-6), 122.63(\mathrm{C}-10), 125.09$ (C-10a), $127.24(\mathrm{C}-8 \mathrm{a})$, 129.51 (C-5), 130.24 (C-4b), 133.43 (C-9), 135.95 (C-2), 138.67 (C-4a), 140.16 (C-3), 159.44 (C-7), 185.61 (C-4), 188.27 (C-1).

Data for 43. $\mathrm{Mp} 111^{\circ} \mathrm{C}\left(\right.$ ref. $\left.^{18)}: 106.5-108.5^{\circ} \mathrm{C}\right)$. IR: $v=1665 \mathrm{~cm}^{-1}(\mathrm{C}=\mathrm{O}), 1610(\mathrm{C}=\mathrm{C}), 1455$, 1295, 1265, 1095, 825; UV: $\lambda_{\max }(\lg \varepsilon)=227 \mathrm{~nm}$ (4.444), 261 (4.063), 299 (4.150), 368 (3.210), 433 (3.145); ${ }^{1} \mathrm{H}$ NMR (300 MHz): $\delta=3.97$ (s, 3H, $\left.\mathrm{OCH}_{3}\right), 6.83(\mathrm{~d}, J=10 \mathrm{~Hz}, 1 \mathrm{H}, 2-$ H), 7.07 (d, $J=8 \mathrm{~Hz}, 1 \mathrm{H}, 6-\mathrm{H}), 7.08$ (d, $J=10 \mathrm{~Hz}, 1 \mathrm{H}, 3-\mathrm{H}), 7.47$ (d, $J=8 \mathrm{~Hz}, 1 \mathrm{H}, 8-\mathrm{H})$, $7.59\left(\mathrm{dd}, J_{6,7}=8 \mathrm{~Hz}, J_{7,8}=8 \mathrm{~Hz}, 1 \mathrm{H}, 7-\mathrm{H}\right), 8.01(\mathrm{~d}, J=9 \mathrm{~Hz}, 1 \mathrm{H}, 10-\mathrm{H}), 8.07(\mathrm{~d}, J=9 \mathrm{~Hz}$, $1 \mathrm{H}, 9-\mathrm{H})$.

Data for 76. $\mathrm{Mp} 150^{\circ} \mathrm{C}$. IR: $v=1643 \mathrm{~cm}^{-1}(\mathrm{C}=\mathrm{O}), 1607(\mathrm{C}=\mathrm{C}), 1552,1433,1285,1252$, 1134, 1123, 1066, 1028, 840; UV: $\lambda_{\max }(\lg \varepsilon)=215 \mathrm{~nm}$ (4.310), 255 (4.283), $460(3.550) ;{ }^{1} \mathrm{H}$ NMR (400 MHz): $\delta=2.74(\mathrm{~m}, 4 \mathrm{H}, 9-, 10-\mathrm{H}), 3.85\left(\mathrm{~s}, 3 \mathrm{H}, \mathrm{OCH}_{3}\right), 6.75(\mathrm{~d}, J=10 \mathrm{~Hz}, 1 \mathrm{H}, 2-$ 
H), $6.77(\mathrm{~d}, J=3 \mathrm{~Hz}, 1 \mathrm{H}, 8-\mathrm{H}), 6.78(\mathrm{~d}, J=10 \mathrm{~Hz}, 1 \mathrm{H}, 3-\mathrm{H}), 6.84\left(\mathrm{dd}, J_{5,6}=9 \mathrm{~Hz}, J_{6,8}=3\right.$ $\mathrm{Hz}, 1 \mathrm{H}, 6-\mathrm{H}), 8.04$ (d, $J=9 \mathrm{~Hz}, 1 \mathrm{H}, 5-\mathrm{H}) . \mathrm{MS}\left(70^{\circ} \mathrm{C} \mathrm{m} / \mathrm{z}(\%)=240\left(100, \mathrm{M}^{+}\right), 197\right.$ (31), 169 (17), 158 (18), 115 (24). Anal. Calcd for $\mathrm{C}_{15} \mathrm{H}_{12} \mathrm{O}_{3}$ : C, 74.99; H, 5.03. Found: C, 75.25; H, 5.14 .

\section{8-Methoxy-1,4-phenanthrenequinone (46) and 9-hydroxy-8-methoxy-1,4-} phenanthrenequinone (57)

Data for 46. $\mathrm{Mp} 208^{\circ} \mathrm{C}\left(\right.$ ref. $\left.^{18)}: 208-209^{\circ} \mathrm{C}\right)$. IR: $v=1655 \mathrm{~cm}^{-1}(\mathrm{C}=\mathrm{O}), 1610(\mathrm{C}=\mathrm{C}), 1580$, 1470, 1305, 1270, 1240, 1120, 840; UV: $\lambda_{\max }(\lg \varepsilon)=224$ nm (4.519), 257 (4.059), 299 (4.231) 367 (3.270), 450 (3.187); ${ }^{1} \mathrm{H}$ NMR: $\delta=4.02$ (s, 3H, $\mathrm{OCH}_{3}$ ), 6.91 ( s, 2H, 2-, 3-H), $6.94(\mathrm{~d}, J=9 \mathrm{~Hz}, 1 \mathrm{H}, 7-\mathrm{H}), 7.61$ (t, $J=9 \mathrm{~Hz}, 1 \mathrm{H}, 6-\mathrm{H}), 8.09$ (d, $J=9 \mathrm{~Hz}, 1 \mathrm{H}, 10-\mathrm{H}), 8.66$ (d, $J=9 \mathrm{~Hz}, 1 \mathrm{H}, 9-\mathrm{H}), 9.07(\mathrm{~d}, J=9 \mathrm{~Hz}, 1 \mathrm{H}, 5-\mathrm{H}) ;{ }^{13} \mathrm{C} \mathrm{NMR}: \delta=55.75\left(\mathrm{OCH}_{3}\right), 106.52(\mathrm{C}-7)$, 119.65 (C-5), 121.04 (C-10), 126.65 (C-10a), 128.94 (C-8a), 129.10 (C-9), 130.33 (C-6), 130.98 (C-4b), 132.53 (C-4a), 135.61 (C-2), 140.63 (C-3), 155.33 (C-8), 185.82 (C-4), 187.88 (C-1).

Data for 57. $\mathrm{Mp} 238^{\circ} \mathrm{C}$. IR: $v=3260 \mathrm{~cm}^{-1}(\mathrm{OH}), 1660(\mathrm{C}=0), 1650,1600(\mathrm{C}=\mathrm{C}), 1565,1310$, 1215, 1130, 1105, 1005, 845; UV: $\lambda_{\max }(\lg \varepsilon)=218 \mathrm{~nm}$ (4.458), 256 (4.032), $297 \mathrm{sh}$ (4.210), 307 (4.271), 329 (3.430), 480 (3.372); ${ }^{1} \mathrm{H}$ NMR: $\delta=4.12$ (s, 3H, $\left.\mathrm{OCH}_{3}\right), 6.86$ (s, 2H, 2-, 3H), 6.98 (d, J=9 Hz, 1H, 7-H), $7.47(\mathrm{~s}, 1 \mathrm{H}, 10-\mathrm{H}), 7.59$ (t, $J=9 \mathrm{~Hz}, 1 \mathrm{H}, 6-\mathrm{H}), 9.31$ (d, $J=9$ $\mathrm{Hz}, 1 \mathrm{H}, 5-\mathrm{H}), 10.34$ (s, 1H, OH); MS (120 $\left.{ }^{\circ} \mathrm{C}\right): \mathrm{m} / \mathrm{z}(\%)=254\left(100, \mathrm{M}^{+}\right), 239$ (82), $226(59)$, 211 (84), 183 (83), 172 (55), 155 (73). Anal. Calcd for $\mathrm{C}_{15} \mathrm{H}_{10} \mathrm{O}_{4}$ : C, 70.87; H, 3.96. Found: C, 70.60; H, 4.35 .

\section{5,8-Dimethoxy-1,4-phenanthrenequinone (50) and 9-hydroxy-5,8-dimethoxy-1,4-} phenanthrenequinone (66)

Data for 50. Mp $176^{\circ} \mathrm{C}\left(\right.$ ref. $\left.^{18)}: 173-175^{\circ} \mathrm{C}\right)$. IR: $v=1660 \mathrm{~cm}^{-1}(\mathrm{C}=\mathrm{O}), 1605(\mathrm{C}=\mathrm{C}), 1590$, 1460, 1300, 1260, 1100, 1020, 815; UV: $\lambda_{\max }(\lg \varepsilon)=220 \mathrm{~nm}$ (4.464), 227 (4.467), $260 \mathrm{sh}$ (3.994), $295 \mathrm{sh}$ (4.025), 313 (4.135), $350 \mathrm{sh}$ (3.443), 399 (3.031), 495 (2.906); ${ }^{1} \mathrm{H} \mathrm{NMR}: \delta=$ $3.89\left(\mathrm{~s}, 3 \mathrm{H}, \mathrm{OCH}_{3}\right), 3.94\left(\mathrm{~s}, 3 \mathrm{H}, \mathrm{OCH}_{3}\right), 6.76$ (d, $\left.J=10 \mathrm{~Hz} ; 1 \mathrm{H}, 2-\mathrm{H}\right), 6.86$ (d, $J=8 \mathrm{~Hz}, 1 \mathrm{H}$, 7 -H), 6.93 (d, J=8 Hz, 2H, 6-H), 7.04 (d, J=10 Hz, 1H, 3-H), 8.01 (d, J=9 Hz, 1H, 10-H), $8.44(\mathrm{~d}, J=9 \mathrm{~Hz}, 1 \mathrm{H}, 9-\mathrm{H}) ;{ }^{13} \mathrm{H}$ NMR: $\delta=56.14\left(\mathrm{OC}_{3}\right), 56.27\left(\mathrm{OCH}_{3}\right), 107.65(\mathrm{C}-6), 109.46$ 
(C-7), 121.19 (C-10), 121.82 (C-10a), 127.22 (C-9), 129.65 (C-8a), 132.56 (C-4b), 133.27 (C4a), 134.76 (C-2), 140.58 (C-3), 149.61 (C-8), 150.95 (C-5), 184.80 (C-4), 186.13 (C-1).

Data for 66. Mp $169^{\circ} \mathrm{C}$. IR: $v=3205 \mathrm{~cm}^{-1}(\mathrm{OH}), 1665(\mathrm{C}=\mathrm{O}), 1655,1610(\mathrm{C}=\mathrm{C}), 1510$, 1450, 1395, 1295, 1110, 820; UV: $\lambda_{\max }(\lg \varepsilon)=210 \mathrm{~nm}$ (4.268), 225 (4.245), 261 (4.276), 298 (3.921), 350 (3.761), 392 (3.551), 500 (2.780); ${ }^{1} \mathrm{H}$ NMR: $\delta=3.90$ (s, 3H, OCH3), 4.06 (s, $3 \mathrm{H}$, $\left.\mathrm{OCH}_{3}\right), 6.66$ (d, $\left.J=10 \mathrm{~Hz}, 1 \mathrm{H}, 2-\mathrm{H}\right), 6.92(\mathrm{~s}, 2 \mathrm{H}, 6-, 7-\mathrm{H}), 6.93$ (d, $\left.J=10 \mathrm{~Hz}, 1 \mathrm{H}, 3-\mathrm{H}\right), 7.38$ (s, 1H, 10-H), $10.18(\mathrm{~s}, 1 \mathrm{H}, \mathrm{OH}) ; \mathrm{MS}\left(170^{\circ} \mathrm{C}\right): \mathrm{m} / \mathrm{z}(\%)=284\left(100, \mathrm{M}^{+}\right), 269(48), 241$ (47). Anal. Calcd for $\mathrm{C}_{16} \mathrm{H}_{12} \mathrm{O}_{5}$ : C, 67.60; H, 4.25. Found: C, 67.33; H, 4.29.

\section{6,7-Dimethoxy-1,4-phenanthrenequinone (51) and 9,10-dihydro-6,7-dimethoxy-1,4- phenanthrenequinone (78)}

Data for 51. $\mathrm{Mp} 236^{\circ} \mathrm{C}\left(\right.$ ref. $\left.^{18)}: 236^{\circ} \mathrm{C}\right)$. IR: $v=1660 \mathrm{~cm}^{-1}(\mathrm{C}=\mathrm{O}), 1610(\mathrm{C}=\mathrm{C}), 1585,1285$, 1310, 1260, 1075, 1020, 845; UV: $\lambda_{\max }(\lg \varepsilon)=145 \mathrm{~nm}$ (4.639), $285 \mathrm{sh}$ (3.973), $297 \mathrm{sh}$ (3.843), 425 (3.783); ${ }^{1} \mathrm{H}$ NMR: $\delta=4.02\left(\mathrm{~s}, 3 \mathrm{H}, \mathrm{OCH}_{3}\right), 4.09\left(\mathrm{~s}, 3 \mathrm{H}, \mathrm{OCH}_{3}\right), 6.87(\mathrm{~s}$, 2H, 2-, 3-H), 7.07 (s, 1H, 8-H), 7.97 (s, 2H, 9-, 10-H), 9.02 (s, 1H, 5-H); ${ }^{13} \mathrm{C}$ NMR: $\delta=55.90$ $\left(\mathrm{OCH}_{3}\right), 56.11\left(\mathrm{OCH}_{3}\right), 106.17(\mathrm{C}-5), 106.68(\mathrm{C}-8), 120.85$ (C-10), $125.27(\mathrm{C}-10 \mathrm{a}), 126.40$ (C-8a), 130.72 (C-4b), 132.87 (C-9), 133.87 (C-4a), 135.99 (C-2), 140.34 (C-3), 151.35 (C-7), 153.22 (C-6), 185.69 (C-4), 188.39 (C-1).

Data for 78. Mp $174^{\circ} \mathrm{C}$. IR: $v=1645 \mathrm{~cm}^{-1}(\mathrm{C}=\mathrm{O}), 1600(\mathrm{C}=\mathrm{C}), 1550,1510,1260,1060$; $\mathrm{UV}$ : $\lambda_{\max }(\lg \varepsilon)=219 \mathrm{~nm}$ (4.375), 257 (4.121), 287 (4.057), 498 (3.467); ${ }^{1} \mathrm{H}$ NMR (400 MHz): $\delta=$ $2.73(\mathrm{~m}, 4 \mathrm{H}, 9-, 10-\mathrm{H}), 3.93\left(\mathrm{~s}, 3 \mathrm{H}, \mathrm{OCH}_{3}\right), 3.94\left(\mathrm{~s}, 3 \mathrm{H}, \mathrm{OCH}_{3}\right), 6.74$ (d, J=10 Hz, 1H, 2-H), $6.75(\mathrm{~s}, 1 \mathrm{H}, 8-\mathrm{H}), 6.79(\mathrm{~d}, J=10 \mathrm{~Hz}, 1 \mathrm{H}, 3-\mathrm{H}), 7.77(\mathrm{~s}, 1 \mathrm{H}, 5-\mathrm{H}) ; \mathrm{MS}\left(100^{\circ} \mathrm{C}\right): \mathrm{m} / \mathrm{z}(\%)=270$ $\left(100, \mathrm{M}^{+}\right), 255$ (7), 227 (16), 184 (8). Anal. Calcd for $\mathrm{C}_{16} \mathrm{H}_{14} \mathrm{O}_{4}$ : C, 71.10; H, 5.22. Found: C, $71.01 ; \mathrm{H}, 5.19$.

6,8-Dimethoxy-1,4-phenanthrenequinone (52). $\mathrm{Mp} 252^{\circ} \mathrm{C}$. IR: $v=1655 \mathrm{~cm}^{-1}(\mathrm{C}=\mathrm{O}), 1645$, $1615(\mathrm{C}=\mathrm{C}), 1610,1580,1405,1305,1260,1155,850$; UV: $\lambda_{\max }(\lg \varepsilon)=230 \mathrm{~nm}(4.578), 253$ sh (4.024), 299 (4.175), 307 (4.214), 378 (3.429), 503 (3.334); ${ }^{1} \mathrm{H}$ NMR (250 MHz): $\delta=4.00$ (s, 3H, $\left.\mathrm{OCH}_{3}\right), 4.02\left(\mathrm{~s}, 3 \mathrm{H}, \mathrm{OCH}_{3}\right), 6.63(\mathrm{~d}, J=2 \mathrm{~Hz}, 1 \mathrm{H}, 7-\mathrm{H}), 6.93(\mathrm{~d}, J=9 \mathrm{~Hz}, 1 \mathrm{H}, 2-\mathrm{H})$, 6.95 (d, $J=9 \mathrm{~Hz}, 1 \mathrm{H}, 3-\mathrm{H}), 8.01$ (d, $J=9 \mathrm{~Hz}, 1 \mathrm{H}, 10-\mathrm{H}), 8.60$ (dd, $J_{9,10}=9 \mathrm{~Hz}, J_{5,9}=1 \mathrm{~Hz}$, $1 \mathrm{H}, 9-\mathrm{H}), 8.68\left(\mathrm{dd}, J_{5,8}=2 \mathrm{~Hz}, J_{5,9}=1 \mathrm{~Hz}, 1 \mathrm{H}, 5-\mathrm{H}\right) ;{ }^{13} \mathrm{C}$ NMR: $\delta=55.61\left(\mathrm{OCH}_{3}\right), 55.78$ 
$\left(\mathrm{OCH}_{3}\right), 97.46$ (C-5), 100.07 (C-7), 119.15 (C-10), 124.84 (C-10a), 125.64 (C-8a), 129.10 (C-9), 132.50 (C-4b), 133.20 (C-4a), 135.57 (C-2), 140.88 (C-3), 156.36 (C-8), 162.35 (C-6), $186.20(\mathrm{C}-1)$; $\mathrm{MS}\left(110^{\circ} \mathrm{C}\right): \mathrm{m} / \mathrm{z}(\%)=268\left(100, \mathrm{M}^{+}\right), 225(59), 195(58), 182$

(47), 169 (40), 154 (44), 141 (42), 126 (45). Anal. Calcd for $\mathrm{C}_{16} \mathrm{H}_{12} \mathrm{O}_{4}$ : C, 71.64; H, 4.51. Found: C, 71.69; H, 4.30 .

\section{7,8-Dimethoxy-1,4-phenanthrenequinone (54), 9,10-dihydro-7,8-dimethoxy-1,4-} phenanthrenequinone (79) and 9-hydroxy-7,8-dimethoxy-1,4-phenanthrenequinone (68)

Data for 54. $\mathrm{Mp} 198^{\circ} \mathrm{C}$ (ref. ${ }^{18)}$ : $\left.196-198^{\circ} \mathrm{C}\right)$. IR: $v=1650 \mathrm{~cm}^{-1}(\mathrm{C}=\mathrm{O}), 1600(\mathrm{C}=\mathrm{C}), 1585$, 1475, 1305, 1275, 1075, 1000, 840; UV: $\lambda_{\max }(\lg \varepsilon)=233 \mathrm{~nm}$ (4.574), $252 \mathrm{sh}(4.153), 306$ (4.156), 387 (3.985), 450 (3.178); ${ }^{1} \mathrm{H}$ NMR: $\delta=4.00$ (s, 3H, $\mathrm{OCH}_{3}$ ), 4.04 (s, $3 \mathrm{H}, \mathrm{OCH}_{3}$ ), 6.90 (s, 2H, 2-, 3-H), 7.48 (d, $J=10 \mathrm{~Hz}, 1 \mathrm{H}, 6-\mathrm{H}), 8.09$ (d, $J=9 \mathrm{~Hz}, 1 \mathrm{H}, 10-\mathrm{H}), 8.49$ (d, $J=9 \mathrm{~Hz}$, $1 \mathrm{H}, 9-\mathrm{H}), 9.30(\mathrm{~d}, J=10 \mathrm{~Hz}, 1 \mathrm{H}, 5-\mathrm{H}) ;{ }^{13} \mathrm{C}$ NMR: $\delta=56.53\left(\mathrm{OCH}_{3}\right), 61.31\left(\mathrm{OCH}_{3}\right), 118.31$ (C-6), 121.98 (C-10), 124.79 (C-5), 125.09 (C-10a), 127.17 (C-8a), 128.07 (C-9), 130.60 (C4b), 132.54 (C-4a), 135.81 (C-2), 140.14 (C-3), 142.56 (C-8), 150,31 (C-7), 185.61 (C-4), $188.18(\mathrm{C}-1)$.

Data for 79. Mp $143^{\circ} \mathrm{C}$. IR: $v=1655 \mathrm{~cm}^{-1}(\mathrm{C}=\mathrm{O}), 1645(\mathrm{C}=\mathrm{O}), 1595(\mathrm{C}=\mathrm{C}), 1490,1275$, 1065, 850; UV: $\lambda_{\max }(\lg \varepsilon)=216 \mathrm{~nm}$ (4.358), 252 (4.283), 308 (3.681), 459 (3.536); ${ }^{1} \mathrm{H}$ NMR: $\delta=2.75\left(\mathrm{~m}_{\mathrm{c}}, 4 \mathrm{H}, 9-, 10-\mathrm{H}\right), 3.79\left(\mathrm{~s}, 3 \mathrm{H}, \mathrm{OCH}_{3}\right), 3.90\left(\mathrm{~s}, 3 \mathrm{H}, \mathrm{OCH}_{3}\right), 6.74(\mathrm{~s}, 2 \mathrm{H}, 2-3-\mathrm{H})$, $6.83(\mathrm{~d}, J=8 \mathrm{~Hz}, 1 \mathrm{H}, 5-\mathrm{H})$; MS $\left(100^{\circ} \mathrm{C}\right): \mathrm{m} / \mathrm{z}(\%)=270\left(100, \mathrm{M}^{+}\right), 255(25), 239(21), 227$ (20), 212 (17). Anal. Calcd for $\mathrm{C}_{16} \mathrm{H}_{14} \mathrm{O}_{4}:$ C, 71.10; H, 5.22. Found: C, 70.96, H 5.11.

Data for 68. Mp $204^{\circ} \mathrm{C}$. IR: $v=3225 \mathrm{~cm}^{-1}(\mathrm{OH}), 1665(\mathrm{C}=\mathrm{O}), 1650,1610(\mathrm{C}=\mathrm{C}), 1605$, 1555, 1510, 1470, 1300, 1280, 1100, 1065, 850; UV: $\lambda_{\max }(\lg \varepsilon)=226 \mathrm{~nm}(4.446), 250$ (4.339), 316 (4.275), 386 (3.315), 490 (3.320); ${ }^{1} \mathrm{H}$ NMR (300 MHz): $\delta=4.05$ (s, $3 \mathrm{H}, \mathrm{OCH}_{3}$ ), 4.12 (s, 3H, $\left.\mathrm{OCH}_{3}\right), 6.85$ (s, 2H, 2-, 3-H), 7.46 (s, 1H, 10-H), 7.49 (d, J=10 Hz, 1H, 6H), $9.50(\mathrm{~d}, J=10 \mathrm{~Hz}, 1 \mathrm{H}, 5 \mathrm{H}), 10.76(\mathrm{~s}, 1 \mathrm{H}, \mathrm{OH}) ; \mathrm{MS}\left(120^{\circ} \mathrm{C}\right): \mathrm{m} / \mathrm{z}(\%)=284\left(100, \mathrm{M}^{+}\right), 269$ (65), 241 (47), 213 (-14). Anal. Calcd for $\mathrm{C}_{16} \mathrm{H}_{12} \mathrm{O}_{5}$ : C, 67.60; H, 4.25. Found: C, 67.54; H, 4.69.

5,6,7-Trimethoxy-1,4-phenanthrenequinone (65). mp $139^{\circ} \mathrm{C}$. IR: $v=1675 \mathrm{~cm}^{-1}(\mathrm{C}=\mathrm{O})$, $1665(\mathrm{C}=\mathrm{O}), 1470,1420,1275,1085$, 835; UV: $\lambda_{\max }(\lg \varepsilon)=210 \mathrm{~nm}$ sh (4.127), 241 (4.529), 
286 (4.074), 301 (4.055), 392 (3.674); ${ }^{1} \mathrm{H}$ NMR: $\delta=3.96\left(\mathrm{~s}, 3 \mathrm{H}, \mathrm{OCH}_{3}\right), 4.01\left(\mathrm{~s}, 3 \mathrm{H}, \mathrm{OCH}_{3}\right)$, $4.03\left(\mathrm{~s}, 3 \mathrm{H}, \mathrm{OCH}_{3}\right), 6.79(\mathrm{~d}, J=10 \mathrm{~Hz}, 1 \mathrm{H}, 2-\mathrm{H}), 6.94(\mathrm{~s}, 1 \mathrm{H}, 8-\mathrm{H}), 7.04$ (d, $J=10 \mathrm{~Hz}, 1 \mathrm{H}, 3-$ H), $7.85(\mathrm{~d}, J=9 \mathrm{~Hz}, 1 \mathrm{H}, 10-\mathrm{H}), 7.95(\mathrm{~d}, J=9 \mathrm{~Hz}, 2 \mathrm{H}, 9-\mathrm{H}) ;{ }^{13} \mathrm{C} \mathrm{NMR}: \delta=56.08\left(\mathrm{OCH}_{3}\right)$, $60.87\left(\mathrm{OCH}_{3}\right), 61.13\left(\mathrm{OCH}_{3}\right), 102.73(\mathrm{C}-8), 120.10$ (C-10a), $121.36(\mathrm{C}-10), 130.72(\mathrm{C}-8 \mathrm{a})$, 131.68 (C-9), 133.27 (C-4b), 134.64 (C-4a), 135.09 (C-2), 140.23 (C-3), 143.72 (C-7), 150.23 (C-6), 155.62 (C-5), 184.61 (C-4), 186.48 (C-1); MS $\left(100^{\circ} \mathrm{C}\right): \mathrm{m} / \mathrm{z}(\%)=298\left(100, \mathrm{M}^{+}\right), 283$ (47), 255 (87), 225 (80), 212 (49), 184 (41), 169 (80), 141 (49). Anal. Calcd for $\mathrm{C}_{17} \mathrm{H}_{14} \mathrm{O}_{5}:+$ $0.2 \mathrm{CHCl}_{3} \mathrm{C}, 65.12 ; \mathrm{H}, 4.44$. Found: $\mathrm{C}, 65.35 ; \mathrm{H}, 4.44$.

6,7,8-Trimethoxy-1,4-phenanthrenequinone (67) and 9-hydroxy-6,7,8-trimethoxy-1,4phenanthrenequinone (75)

Data for 62. $\mathrm{Mp} 139^{\circ} \mathrm{C}$. IR: $v=1665 \mathrm{~cm}^{-1}(\mathrm{C}=\mathrm{O}), 1650,1610(\mathrm{C}=\mathrm{C}), 1585,1410,1310$, 1265, 1110, 1075, 1040, 855; UV: $\lambda_{\max }(\lg \varepsilon)=239 \mathrm{~nm}$ (6.616), 290 (4.055), 301 (4.046), 401 (3.608); ${ }^{1} \mathrm{H}$ NMR: $\delta=4.03\left(\mathrm{~s}, 3 \mathrm{H}, \mathrm{OCH}_{3}\right), 4.06\left(\mathrm{~s}, 3 \mathrm{H}, \mathrm{OCH}_{3}\right), 4.09\left(\mathrm{~s}, 3 \mathrm{H}, \mathrm{OCH}_{3}\right), 6.91(\mathrm{~s}$, 2H, 2-, 3-H), 7.97 (d, $J=9 \mathrm{~Hz}, 1 \mathrm{H}, 10-\mathrm{H}), 8.39$ (d, $J=9 \mathrm{~Hz}, 1 \mathrm{H}, 9-\mathrm{H}), 8.89$ (s, 1H, 5-H); ${ }^{13} \mathrm{C}$ NMR: $\delta=56.05\left(\mathrm{OCH}_{3}\right), 61.09\left(\mathrm{OCH}_{3}\right), 61.65\left(\mathrm{OCH}_{3}\right), 102.40(\mathrm{C}-5), 120.04(\mathrm{C}-10), 125.08$ (C-10a), 127.66 (C-8a), 128.42 (C-9), 128.75 (C-4b), 131.98 (C-4a), 135.76 (C-2), 140.49. (C-3), 142.63 (C-8), 147.43 (C-7), 156.68 (C-6), 185.81 (C-4), 188.23 (C-1); MS (50 C): m/z $(\%)=198\left(100, \mathrm{M}^{+}\right), 289$ (82), 255 (82), 240 (77), 223 (44), 212 (59), 197 (42), 184 (47), 169 (69). Anal. Calcd for $\mathrm{C}_{17} \mathrm{H}_{14} \mathrm{O}_{5}$ : C, 68.45; H, 4.73. Found: C, 68.29; H, 4.56.

Data for 97. Mp $217^{\circ} \mathrm{C}$. IR: $v=1660 \mathrm{~cm}^{-1}(\mathrm{C}=\mathrm{O}), 1645,1610(\mathrm{C}=\mathrm{C}), 1590,1480,1305$, 1270, 1110. UV: $\lambda_{\max }(\lg \varepsilon)=225 \mathrm{~nm}$ (4.399), 246 (4.571), $301 \mathrm{sh}$ (4.185), 311 (4.232), 390 (3.497), 486 (3.378); ${ }^{1} \mathrm{H} \mathrm{NMR}: \delta=4.00$ (s, 3H, $\left.\mathrm{OCH}_{3}\right), 4.07$ (s, 3H, $\left.\mathrm{OCH}_{3}\right), 4.17$ (s, 3H, $\left.\mathrm{OCH}_{3}\right), 6.82(\mathrm{~s}, 2 \mathrm{H}, 2-, 3-\mathrm{H}), 7.35$ (s, 1H, 10-H), 9.08 (s, 1H, 5-H), 10.51 (s, 1H, OH); MS $\left(120^{\circ} \mathrm{C}\right): m / z(\%)=314\left(100, \mathrm{M}^{+}\right), 299$ (47), 271 (36), 256 (16), 185 (19). Anal. Calcd for $\mathrm{C}_{17} \mathrm{H}_{14} \mathrm{O}_{26}: \mathrm{C}, 64.97 ; \mathrm{H}, 4.49$. Found: $\mathrm{C}, 64.76 ; \mathrm{H}, 4.46$.

6-Benzyloxy-7-methoxy-1,4-phenanthrenequinone (53). Yield $772 \mathrm{mg}(66 \%) . \mathrm{mp} 153^{\circ} \mathrm{C}$. IR: $v=1655 \mathrm{~cm}^{-1}(\mathrm{C}=\mathrm{O}), 1615,(\mathrm{C}=\mathrm{C}), 1510,1485,1070,840 ; \mathrm{UV}: \lambda_{\max }(\lg \varepsilon)=215 \mathrm{~nm} \mathrm{sh}$ (4.248), 246 (4.689), 273 sh (4.12-3), 285 (4.040), 301 sh (3.875), 430 (3.738); ${ }^{1} \mathrm{H}$ NMR: $\delta=$ $4.11\left(\mathrm{~s}, 3 \mathrm{H}, \mathrm{OCH}_{3}\right), 5.32\left(\mathrm{~s}, 2 \mathrm{H}, \mathrm{CH}_{2}\right), 6.91$ (d, $\left.J=10 \mathrm{~Hz}, 1 \mathrm{H}, 2-\mathrm{H}\right), 6.92$ (d, $J=10 \mathrm{~Hz}, 1 \mathrm{H}$, 3-H), 7.17 (s, 1H, 8-H), $7.42\left(\mathrm{~m}_{\mathrm{c}}, 5 \mathrm{H}, \mathrm{C}_{6} \mathrm{H}_{5}\right), 7.94$ (d, J=8 Hz, 1H, 10-H), 8.02 (d, J=8 Hz, 
1H, 9-H), 9.10 (s, 1H, 5-H); MS $\left(35^{\circ} \mathrm{C}\right): \mathrm{m} / \mathrm{z}(\%)=344\left(15, \mathrm{M}^{+}\right), 242$ (16), 91 (100, Bzl). Anal. Calcd for $\mathrm{C}_{22} \mathrm{H}_{16} \mathrm{O}_{4}+2 \mathrm{H}_{2} \mathrm{O}: \mathrm{C}, 69.47$; H, 5.30. Found: C, 69.95; H, 5.12.

7-Benzyloxy-8-methoxy-1,4-phenanthrenequinone (56). Yield: $397 \mathrm{mg} \mathrm{(34 \% );} \mathrm{mp} 168^{\circ} \mathrm{C}$. IR: $v=1650 \mathrm{~cm}^{-1}(\mathrm{C}=\mathrm{O}), 1609(\mathrm{C}=\mathrm{C}), 1587,1479,1311,1272,1232,1114,1040 ; \mathrm{UV}: \lambda_{\max }$ $(\lg \varepsilon)=234 \mathrm{~nm}$ (4.642), $255 \mathrm{sh}$ (4.162), 304 (4.204), 387 (3.531), 460 (3.210); ${ }^{1} \mathrm{H}$ NMR (400 $\mathrm{MHz}): \delta=4.04\left(\mathrm{~s}, 3 \mathrm{H}, \mathrm{OCH}_{3}\right), 5.33\left(\mathrm{~s}, 2 \mathrm{H}, \mathrm{CH}_{2}\right), 6.93(\mathrm{~s}, 2 \mathrm{H}, 2-, 3-\mathrm{H}), 7.41\left(\mathrm{~m}_{\mathrm{c}}, 5 \mathrm{H}, \mathrm{C}_{6} \mathrm{H}_{5}\right)$, $7.53(\mathrm{~d}, J=10 \mathrm{~Hz}, 1 \mathrm{H}, 6-\mathrm{H}), 8.15(\mathrm{~d}, J=9 \mathrm{~Hz}, 1 \mathrm{H}, 10-\mathrm{H}), 8.54$ (d, $J=9 \mathrm{~Hz}, 1 \mathrm{H}, 9-\mathrm{H}), 9.28$ $(\mathrm{d}, J=10 \mathrm{~Hz}, 1 \mathrm{H}, 5-\mathrm{H}) ; \mathrm{MS}\left(120^{\circ} \mathrm{C}\right): \mathrm{m} / \mathrm{z}(\%)=344\left(30, \mathrm{M}^{+}\right), 253$ (16, M - Bzl), 225 (17), 91 (100, Bzl). Anal. Calcd for $\mathrm{C}_{22} \mathrm{H}_{16} \mathrm{O}_{4}: \mathrm{C}, 76.73 ; \mathrm{H}, 4.68$. Found: C,76.63; H, 4.51.

8-Benzyloxy-7-methoxy-1,4-phenanthrenequinone (55). Yield: $337 \mathrm{mg}(29 \%), \mathrm{mp} 156^{\circ} \mathrm{C}$. IR: $v=1650 \mathrm{~cm}^{-1}(\mathrm{C}=\mathrm{O}), 1605(\mathrm{C}=\mathrm{C}), 1590,1475,1305,1270,1220,1110,1080,980,840$; $\mathrm{UV}: \lambda_{\max }(\lg \varepsilon)=234 \mathrm{~nm}$ (4.625), $255 \mathrm{sh}$ (4.154), 305 (4.199), 390 (3.545), 434 (3.236); ${ }^{1} \mathrm{H}$ NMR (300 MHz): $\delta=4.07\left(\mathrm{~s}, 3 \mathrm{H}, \mathrm{OCH}_{3}\right), 5.18\left(\mathrm{~s}, 2 \mathrm{H}, \mathrm{CH}_{2}\right), 6.91(\mathrm{~d}, J=10 \mathrm{~Hz}, 1 \mathrm{H}, 2-\mathrm{H})$, $6.93(\mathrm{~d}, J=10 \mathrm{~Hz}, 1 \mathrm{H}, 3-\mathrm{H}), 7.42\left(\mathrm{~m}_{\mathrm{c}}, 5 \mathrm{H}, \mathrm{C}_{6} \mathrm{H}_{5}\right), 7.54$ (d, $\left.J=10 \mathrm{~Hz}, 1 \mathrm{H}, 6-\mathrm{H}\right), 8.06$ (d, $J=9$ $\mathrm{Hz}, 1 \mathrm{H}, 10-\mathrm{H}), 8.47\left(\mathrm{dd}, J_{9,10}=9 \mathrm{~Hz}, J_{5,9}=1 \mathrm{~Hz}, 1 \mathrm{H}, 9-\mathrm{H}\right) 9.35\left(\mathrm{dd}, J_{5,6}=10 \mathrm{~Hz}, J_{5,9}=1 \mathrm{~Hz}\right.$, 1H, 5-H); $\operatorname{MS}\left(70^{\circ} \mathrm{C}\right): m / z(\%)=344\left(19, \mathrm{M}^{+}\right), 253$ (28, M - Bzl), 225 (14), 91 (100, Bzl), 84 (28). Anal. Calcd for $\mathrm{C}_{22} \mathrm{H}_{16} \mathrm{O}_{4}$ (344.37) Ber. C 76.73 H 4.68. Found: C, 76.55; H, 4.47.

9,10-Dihydro-5,7-dimethoxy-1,4-phenanthrenequinone (77). Yield: $348 \mathrm{mg}$ (38\%), mp $110^{\circ} \mathrm{C} . \mathrm{IR}: v=1645 \mathrm{~cm}^{-1}(\mathrm{C}=\mathrm{O}), 1602(\mathrm{C}=\mathrm{C}), 1558,1352,1303,1281,1231,1155,1102$; $\mathrm{UV}: \lambda_{\max }(\lg \varepsilon)=221 \mathrm{~nm}$ (4.390), 249 (4.132), 287 (3.990), 423 (3.519); ${ }^{1} \mathrm{H}$ NMR (400 $\mathrm{MHz}): \delta=2.63(\mathrm{~m}, 4 \mathrm{H}, 9-, 10-\mathrm{H}), 3.78\left(\mathrm{~s}, 3 \mathrm{H}, \mathrm{OCH}_{3}\right), 3.84\left(\mathrm{~s}, 3 \mathrm{H}, \mathrm{OCH}_{3}\right), 6.41(\mathrm{~d}, J=2 \mathrm{~Hz}$, 1H, 8-H), 6.43 (d, $J=2 \mathrm{~Hz}, 1 \mathrm{H}, 6-\mathrm{H}), 6.70$ (d, $J=10 \mathrm{~Hz}, 1 \mathrm{H}, 2-\mathrm{H}), 6.80$ (d, $J=10 \mathrm{~Hz}, 1 \mathrm{H}, 3-$ $\mathrm{H})$; $\operatorname{MS}\left(75^{\circ} \mathrm{C}\right): m / z(\%)=270\left(100, \mathrm{M}^{+}\right), 153(17), 227(21), 188$ (23). Anal. Calcd for $\mathrm{C}_{16} \mathrm{H}_{14} \mathrm{O}_{6}(270.29)$ C $71.10 \mathrm{H}$ 5.22. Found: C 71.62 H 5.23.

\section{3-Methoxy-1,4-phenanthrenequinone (1) and 2-methoxy-1,4-phenanthrenequinone (42)}

Data for 1. Mp $170^{\circ} \mathrm{C}$ (ref. $\left.{ }^{1)}: 170-172{ }^{\circ} \mathrm{C}\right)$. IR: $v=1671 \mathrm{~cm}^{-1}(\mathrm{C}=\mathrm{O}), 1647(\mathrm{C}=\mathrm{O}), 1624$ $(\mathrm{C}=\mathrm{C}), 1457,1334,1320,1250,1240,1195,1179$ 1102, 834; UV: $\lambda_{\max }(\lg \varepsilon)=227 \mathrm{~nm}$ (4.539), $275 \mathrm{sh}$ (4.322), 281 (4.353), 313 (3.846), 369 (3.534); ${ }^{1} \mathrm{H}$ NMR (250 MHz): $\delta=3.92$ $\left(\mathrm{s}, 3 \mathrm{H}, \mathrm{OCH}_{3}\right), 6.11(\mathrm{~s}, 1 \mathrm{H}, 2 \mathrm{H}), 7.60\left(\mathrm{ddd}, J_{6,7}=7 \mathrm{~Hz}, J_{7,8}=8 \mathrm{~Hz}, J_{5,7}=1 \mathrm{~Hz}, 1 \mathrm{H}, 7-\mathrm{H}\right), 7.70$ 
(ddd, $\left.J_{5,6}=9 \mathrm{~Hz}, J_{6,7}=7 \mathrm{~Hz}, J_{6,8}=2 \mathrm{~Hz}, 1 \mathrm{H}, 6-\mathrm{H}\right), 7.86$ (ddd, $J_{7,8}=8 \mathrm{~Hz}, J_{6,8}=2 \mathrm{~Hz}, J_{5,8}=1$ $\mathrm{Hz}, 1 \mathrm{H}, 8-\mathrm{H}), 8.14$ (d, $J=9 \mathrm{~Hz}, 1 \mathrm{H}, 9-\mathrm{H}), 8.15$ (d, $J=9 \mathrm{~Hz}, 1 \mathrm{H}, 10-\mathrm{H}), 9.50$ (ddd, $J_{5,6}=9 \mathrm{~Hz}$, $\left.J_{5,7}=1 \mathrm{~Hz}, J_{5,8}=1 \mathrm{~Hz}, 1 \mathrm{H}, 5-\mathrm{H}\right) ;{ }^{13} \mathrm{C} \mathrm{NMR}: \delta=56.58\left(\mathrm{OCH}_{3}\right), 107.10(\mathrm{C}-2), 121.73(\mathrm{C}-10)$, 125.96 (C-10a), 127.49 (C-5), 128.34 (C-7), 128.71 (C-6), 129.90 (C-8a), 130.23 (C-8), 132.50 (C-4b), 135.57 (C-9), 136.14 (C-4a), 160.70 (C-3), 182.26 (C-4), 18514 (C-1); MS $\left(80^{\circ} \mathrm{C}\right): \mathrm{m} / \mathrm{z}(\%)=238\left(100, \mathrm{M}^{+}\right), 223(40), 209$ (14), $181(15), 167$ (14), 152 (26), 139 (91), 126 (25). Anal. Calcd for $\mathrm{C}_{15} \mathrm{H}_{10} \mathrm{O}_{3}$ : C, 75.62; H, 4.23. Found: C, 75.62; H, 4.23.

Data for 42. Mp $135^{\circ} \mathrm{C}$. IR: $v=1680 \mathrm{~cm}^{-1}(\mathrm{C}=\mathrm{O}), 1645(\mathrm{C}=\mathrm{O}), 1620(\mathrm{C}=\mathrm{C}), 1235,1065$, 775; UV: $\lambda_{\max }(\lg \varepsilon)=223 \mathrm{~nm}$ (4.598), 281 (4.450), 312 (3.873), 372 (3.345), $396 \mathrm{sh}$ (3.183); ${ }^{1} \mathrm{H}$ NMR (400 MHz): $\delta=3.92\left(\mathrm{~s}, 3 \mathrm{H}, \mathrm{OCH}_{3}\right), 6.17(\mathrm{~s}, 1 \mathrm{H}, 3-\mathrm{H}), 7.64\left(\mathrm{ddd}, J_{6,7}=8 \mathrm{~Hz}, J_{7,8}=8\right.$ $\left.\mathrm{Hz}, J_{5,7}=1 \mathrm{~Hz}, 1 \mathrm{H}, 7-\mathrm{H}\right), 7.72$ (ddd, $\left.J_{5,6}=9 \mathrm{~Hz}, J_{6,7}=8 \mathrm{~Hz}, J_{6,8}=2 \mathrm{~Hz}, 1 \mathrm{H}, 6-\mathrm{H}\right), 7.89$ (ddd, $\left.J_{7,8}=8 \mathrm{~Hz}, J_{5,8}=1 \mathrm{~Hz}, J_{6,8}=2 \mathrm{~Hz}, 1 \mathrm{H}, 8-\mathrm{H}\right), 8.13(\mathrm{~d}, J=9 \mathrm{~Hz}, 1 \mathrm{H}, 10-\mathrm{H}), 8.21(\mathrm{~d}, J=9 \mathrm{~Hz}$, $1 \mathrm{H}, 9-\mathrm{H}), 9.61\left(\mathrm{ddd}, J_{5,6}=9 \mathrm{~Hz}, J_{5,7}=1 \mathrm{~Hz}, J_{5,8}=1 \mathrm{~Hz}, 1 \mathrm{H}, 5-\mathrm{H}\right) ;{ }^{13} \mathrm{C}$ NMR: $\delta=56.28$ $\left(\mathrm{OCH}_{3}\right), 111.40$ (C-3), 121.80 (C-10), 127.17 (C-10a), 128.36 (C-5), 128.50 (C-7), 128.62 (C6), 128.70 (C-8a), 129.88 (C-8), 131.14 (C-4b), 134.31 (C-9), 136.84 (C-4a), 158.15 (C-2), 181.00 (C-4), $188.12(\mathrm{C}-1)$; MS $\left(100^{\circ} \mathrm{C}\right): \mathrm{m} / \mathrm{z}(\%)=238\left(100, \mathrm{M}^{+}\right), 210(24), 152(25), 139$ (67), 126 (26). Anal. Calcd for $\mathrm{C}_{15} \mathrm{H}_{10} \mathrm{O}_{3}:+0.03 \mathrm{CCl}_{4} \mathrm{C}, 74.33$; $\mathrm{H}, 4.15$. Found: $\mathrm{C}, 74.29 ; \mathrm{H}$, 4.20 .

3,6-Dimethoxy-1,4-phenanthrenequinone (47). Yield: $91 \mathrm{mg}(10 \%), \mathrm{mp} 215{ }^{\circ} \mathrm{C}$. IR: $v=$ $1670 \mathrm{~cm}^{-1}(\mathrm{C}=\mathrm{O}), 1645(\mathrm{C}=\mathrm{O}), 1520(\mathrm{C}=\mathrm{C}), 1590,1460,1240,1220,1090,1025,840$; UV: $\lambda_{\max }(\lg \varepsilon)=237 \mathrm{~nm}$ (4.584), 286 (4.236), $307 \mathrm{sh}$ (3.801), 392 (3.467), 452 (3.424); ${ }^{1} \mathrm{H}$ NMR: $\delta=3.93\left(\mathrm{~s}, 3 \mathrm{H}, \mathrm{OCH}_{3}\right), 4.00\left(\mathrm{~s}, 3 \mathrm{H}, \mathrm{OCH}_{3}\right), 6.12(\mathrm{~s}, 1 \mathrm{H}, 2-\mathrm{H}), 7.26\left(\mathrm{dd}, J_{7,8}=10 \mathrm{~Hz}, J_{5,7}=2\right.$ Hz, 1H, 7-H), 7.77 (d, $J=10 \mathrm{~Hz}, 1 \mathrm{H}, 8-\mathrm{H}), 8.06$ (s, 2H, 9-, 10-H), 9.03 (d, $J=2 \mathrm{~Hz}, 1 \mathrm{H}, 5-$ $\mathrm{H}) ;{ }^{13} \mathrm{H}$ NMR: $\delta=55.49\left(\mathrm{OCH}_{3}\right), 56.49\left(\mathrm{OCH}_{3}\right), 105.38(\mathrm{C}-5), 107.22(\mathrm{C}-2), 119.87(\mathrm{C}-10)$, 121.52 (C-7), 124.36 (C-10a), 130.14 (C-8), 132.06 (C-8a), 132.18 (C-4b), 133.17 (C-4a), 135.30 (C-9), 160.85 (C-3), 161.68 (C-6), 182.46 (C-4), 185.29 (C-1); MS $\left(90^{\circ} \mathrm{C}\right): \mathrm{m} / \mathrm{z}(\%)=$ $268\left(100, \mathrm{M}^{+}\right), 253$ (32), 238 (12), 197 (32), 169 (76), 139 (30), 126 (51). Anal. Calcd for $\mathrm{C}_{16} \mathrm{H}_{12} \mathrm{O}_{4}: \mathrm{C}, 71.64 ; \mathrm{H}, 4.51$. Found: C, 71.08; H, 4.16.

3,7-Dimethoxy-1,4-phenanthrenequinone (48). $\mathrm{mp} 205^{\circ} \mathrm{C}$. IR: $v=1670 \mathrm{~cm}^{-1}(\mathrm{C}=\mathrm{O}), 1645$ $(\mathrm{C}=\mathrm{O}), 1615(\mathrm{C}=\mathrm{C}), 1485,1250,1240,1200,1005,840$; UV: $\lambda_{\max }(\lg \varepsilon)=236 \mathrm{~nm}(4.606)$, 
$252 \mathrm{sh}$ (4.184), 298 (4.288), 315 (3.787), 386 (3.661); ${ }^{1} \mathrm{H}$ NMR: $\delta=3.94$ (s, 1H, $\left.\mathrm{OCH}_{3}\right), 3.94$ $\left(\mathrm{s}, 1 \mathrm{H}, \mathrm{OCH}_{3}\right), 6.09(\mathrm{~s}, 1 \mathrm{H}, 2-\mathrm{H}), 7.13(\mathrm{~d}, J=3 \mathrm{~Hz}, 1 \mathrm{H}, 8-\mathrm{H}), 7.35\left(\mathrm{dd}, J_{5,6}=10 \mathrm{~Hz}, J_{6,8}=3\right.$ Hz, 1H, 6-H), 7.99 (d, $J=9$ Hz, 1H, 10-H), 8.14 (d, J=9 Hz, 1H, 9-H), 9.41 (d, J = $10 \mathrm{~Hz}$, $1 \mathrm{H}, 5-\mathrm{H}) ;{ }^{13} \mathrm{C}$ NMR: $\delta=55.46\left(\mathrm{OCH}_{3}\right), 56.54\left(\mathrm{OCH}_{3}\right), 106.86(\mathrm{C}-8), 107.24(\mathrm{C}-2), 122.58$ (C-6), 122.78 (C-10), 125.30 (C-10a), 126.29 (C-8a), 129.26 (C-5), 130.65 (C-4b), 133.98 (C9), 138.39 (C-4a), 159.27 (C-7), 160.70 (C-3), 182.55 (C-4), 185.24 (C-1); MS (170 C): m/z $(\%)=268\left(100, \mathrm{M}^{+}\right), 253$ (24), 238 (15), 197 (33), 169 (63), 139 (15), $126(31)$.

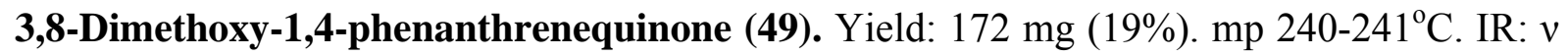
$=1670 \mathrm{~cm}^{-1}(\mathrm{C}=\mathrm{O}), 1645(\mathrm{C}=\mathrm{O}), 1620(\mathrm{C}=\mathrm{C}), 1585,1460,1260,1220,1180,1015,855$; UV: $\lambda_{\max }(\lg \varepsilon)=224 \mathrm{~nm}$ (4.536), 292 (4.398), $320 \mathrm{sh}$ (3.613), 373 (3.359), 460 (3.136); ${ }^{1} \mathrm{H} \mathrm{NMR:}$ $\delta=3.94\left(\mathrm{~s}, 3 \mathrm{H}, \mathrm{OCH}_{3}\right), 4.03\left(\mathrm{~s}, 3 \mathrm{H}, \mathrm{OCH}_{3}\right), 6.13(\mathrm{~s}, 1 \mathrm{H}, 2-\mathrm{H}), 6.94(\mathrm{~d}, J=8 \mathrm{~Hz}, 1 \mathrm{H}, 7-\mathrm{H})$, 7.62 (t, $J=8 \mathrm{~Hz}, 1 \mathrm{H}, 6-\mathrm{H}), 8.15$ (d, $J=9 \mathrm{~Hz}, 1 \mathrm{H}, 10-\mathrm{H}), 8.69$ (d, $J=9 \mathrm{~Hz}, 1 \mathrm{H}, 9-\mathrm{H}), 9.08$ (d, $J=8 \mathrm{~Hz}, 1 \mathrm{H}, 5-\mathrm{H}) ;{ }^{13} \mathrm{C} \mathrm{NMR}: \delta=55.75\left(\mathrm{OCH}_{3}\right), 56.49\left(\mathrm{OCH}_{3}\right), 106.29(\mathrm{C}-7), 107.14(\mathrm{C}-2)$, 119.43 (C-5), 121.03 (C-10), 125.66 (C-10a), 128.72 (C-8a), 129.63 (C-9), 130.56 (C-6), 131.15 (C-4b), 132.98 (C-4a), 155.44 (C-8), 161.01 (C-3), 182.21 (C-4), 185.27 (C-1); MS $\left(100^{\circ} \mathrm{C}\right): \mathrm{m} / \mathrm{z}(\%)=168\left(100, \mathrm{M}^{+}\right), 253$ (57), 238 (45), 197 (49), 169 (67), 139 (51), $126(52)$. Anal. Calcd for $\mathrm{C}_{16} \mathrm{H}_{12} \mathrm{O}_{4}$ : C, 71.64; H, 4.51. Found: C, 71.73; H, 4.49.

\section{3,5,8-Trimethoxy-1,4-phenanthrenequinone (61) and 9-hydroxy-3,5,8-trimethoxy-1,4-} phenanthrenequinone (73)

Data for 61. Mp $219^{\circ} \mathrm{C}$. IR: $v=1670 \mathrm{~cm}^{-1}(\mathrm{C}=\mathrm{O}), 1645(\mathrm{C}=\mathrm{O}), 1610(\mathrm{C}=\mathrm{C}), 1590,1465$, 1260, 1230, 1180, 1095, 1020, 845; UV: $\lambda_{\max }(\lg \varepsilon)=215 \mathrm{~nm}$ (4.513), $235 \mathrm{sh}$ (4.358), 277 (4.198), 308 (4.246), 351 sh (3.507), 490 (2.967); ${ }^{1} \mathrm{H}$ NMR: $\delta=3.91$ (s, $\left.3 \mathrm{H}, \mathrm{OCH}_{3}\right), 3.93$ $\left(\mathrm{OCH}_{3}\right), 3.96\left(\mathrm{~s}, 3 \mathrm{H}, \mathrm{OCH}_{3}\right), 6.01(\mathrm{~s}, 1 \mathrm{H}, 2-\mathrm{H}), 6.89$ (d, $\left.J=9 \mathrm{~Hz}, 1 \mathrm{H}, 7-\mathrm{H}\right), 6.96(\mathrm{~d}, J=9 \mathrm{~Hz}$, $1 \mathrm{H}, 6-\mathrm{H}), 8.06(\mathrm{~d}, J=9 \mathrm{~Hz}, 1 \mathrm{H}, 9-\mathrm{H}), 8.48(\mathrm{~d}, J=9 \mathrm{~Hz}, 1 \mathrm{H}, 10-\mathrm{H}) ;{ }^{13} \mathrm{C} \mathrm{NMR}: \delta=56.00$ $\left(\mathrm{OCH}_{3}\right), 56.16\left(\mathrm{OCH}_{3}\right), 56.48\left(\mathrm{OCH}_{3}\right), 106.17(\mathrm{C}-2), 107.15(\mathrm{C}-6), 109.39(\mathrm{C}-7), 121.14(\mathrm{C}-$ 10), 121.68 (C-10a), 127.73 (C-9), 129.29 (C-8a), 131.89 (C-4b), 132.93 (C-4a), 149.57 (C8), 150.61 (C-5), 163.18 (C-3), 181.38 (C-4), 184.47 (C-1); MS (100 $): m / z ~(\%)=298(100$, $\mathrm{M}^{+}$), 283 (96), 255 (60), 225 (45), 199 (36), 169 (38), 141 (38). Anal. Calcd for $\mathrm{C}_{17} \mathrm{H}_{14} \mathrm{O6}$ : C, 68.45; H, 4.73. Found: C, 68.38; H, 4.70.

Data for 73. Mp $231^{\circ} \mathrm{C}$. IR: $v=1670 \mathrm{~cm}^{-1}(\mathrm{C}=\mathrm{O}), 1645(\mathrm{C}=\mathrm{O}), 1615(\mathrm{C}=\mathrm{C}), 1510,1400$, 
1260, 1195, 1175; UV: $\lambda_{\max }(\lg \varepsilon)=216 \mathrm{~nm}$ (4.433), $265 \mathrm{sh}$ (4.057), 287 (4.338), 315 (4.206), 345 sh (3.670), 366 (3636), 487 (3.200); ${ }^{1} \mathrm{H}$ NMR: $\delta=3.91\left(\mathrm{~s}, 6 \mathrm{H}, \mathrm{OCH}_{3}\right), 4.05$ (s, 3H, $\left.\mathrm{OCH}_{3}\right), 5.97$ (s, 1H, 2-H), 6.92 (s, 2H, 6-, 7-H), 7.42 (s, 1H, 10-H), 10.22 (s, 1H, OH); MS $\left(120^{\circ} \mathrm{C}\right): \mathrm{m} / \mathrm{z}(\%)=314\left(100, \mathrm{M}^{+}\right), 299(58), 297$ (24), 271 (30), 243 (24). Anal. Calcd for $\mathrm{C}_{17} \mathrm{H}_{14} \mathrm{O}_{6}$ : C, 64.97; H, 4.49. Found: C, 64.75; H, 4.46.

3,6,7-Trimethoxy-1,4-phenanthrenequinone (72). Yield: $119 \mathrm{mg}(12 \%) . \mathrm{mp} 250^{\circ} \mathrm{C} . \mathrm{IR}: \mathrm{v}=$ $1670 \mathrm{~cm}^{-1}(\mathrm{C}=\mathrm{O}), 1640(\mathrm{C}=\mathrm{O}), 1620(\mathrm{C}=\mathrm{C}), 1485,1260,1235,1090,1010,835$; UV: $\lambda_{\max }(\lg$ $\varepsilon)=244 \mathrm{~nm}$ (4.372), $262 \mathrm{sh}$ (4.038), 287 (3.929), 295 (3.898), 320 (3.556), 424 (3.639); ${ }^{1} \mathrm{H}$ NMR: $\delta=3.93\left(\mathrm{~s}, 3 \mathrm{H}, \mathrm{OCH}_{3}\right), 4.03\left(\mathrm{~s}, 3 \mathrm{H}, \mathrm{OCH}_{3}\right), 4.03\left(\mathrm{~s}, 3 \mathrm{H}, \mathrm{OCH}_{3}\right), 6.09(\mathrm{~s}, 1 \mathrm{H}, 2-\mathrm{H})$, $7.10(\mathrm{~s}, 1 \mathrm{H}, 8-\mathrm{H}), 8.00(\mathrm{~s}, 2 \mathrm{H}, 9-, 10-\mathrm{H}), 9.06(\mathrm{~s}, 1 \mathrm{H}, 5-\mathrm{H}) ;{ }^{13} \mathrm{C} \mathrm{NMR}: \delta=55.87\left(\mathrm{OCH}_{3}\right)$, $56.04\left(\mathrm{OCH}_{3}\right), 56.43\left(\mathrm{OCH}_{3}\right), 106.03(\mathrm{C}-5), 106.75(\mathrm{C}-8), 107.32$ (C-2), $120.72(\mathrm{C}-10)$, 124.18 (C-10a), 126.60 (C-8a), 131.04 (C-4b), 133.39 (C-9), 133.45 (C-4a), 151.08 (C-7), 153.34 (C-6), 160.65 (C-3), 182.71 (C-4), 185.24 (C-1); MS $\left(120^{\circ} \mathrm{C}\right): \mathrm{m} / \mathrm{z}(\%)=298(100$, $\mathrm{M}^{+}$), 283 (34), 255 (25), 227 (58), 199 (68), 169 (20), 155 (27). Anal. Calcd for $\mathrm{C}_{17} \mathrm{H}_{14} \mathrm{O}_{5}$ : C, 68.45; H, 4.73. Found: C, 68.42; H, 4.45.

\section{3,6,8-Trimethoxy-1,4-phenanthrenequinone (63) and 2,6,8-trimethoxy-1,4-} phenanthrenequinone (58)

Data for 63. $\mathrm{Mp} 228^{\circ} \mathrm{C}$. IR: $v=1660 \mathrm{~cm}^{-1}(\mathrm{C}=\mathrm{O}), 1645(\mathrm{C}=\mathrm{O}), 1625(\mathrm{C}=\mathrm{C}), 1255,1240$, 1230, 1205, 1180, 845; UV: $\lambda_{\max }(\lg \varepsilon)=231 \mathrm{~nm}$ (4.609), 294 (4.308), 388 (3.388), 495 (3.408); ${ }^{1} \mathrm{H}$ NMR (250 MHz): $\delta=3.94\left(\mathrm{~s}, 3 \mathrm{H}, \mathrm{OCH}_{3}\right), 3.99\left(\mathrm{~s}, 3 \mathrm{H}, \mathrm{OCH}_{3}\right), 4.00(\mathrm{~s}, 3 \mathrm{H}$, $\left.\mathrm{OCH}_{3}\right), 6.13$ (s, 1H, 2-H), 6.61 (d, $\left.J=2 \mathrm{~Hz}, 1 \mathrm{H}, 7-\mathrm{H}\right), 8.03$ (d, $\left.J=9 \mathrm{~Hz}, 1 \mathrm{H}, 10-\mathrm{H}\right), 8.58$ (d, $J$ $=9 \mathrm{~Hz}, 1 \mathrm{H}, 9-\mathrm{H}), 8.67(\mathrm{~d}, J=2 \mathrm{~Hz}, 1 \mathrm{H}, 5-\mathrm{H}) ;{ }^{13} \mathrm{C} \mathrm{NMR}: \delta=55.55\left(\mathrm{OCH}_{3}\right), 55.77\left(\mathrm{OCH}_{3}\right)$, $56.49\left(\mathrm{OCH}_{3}\right), 97.38$ (C-5), 99.86 (C-7), 107.14 (C-2), 119.11 (C-10), 123.80 (C-10a), 125.40 (C-8a), 129.72 (C-9), 132.72 (C-4b), 133.66 (C-4a), 156.53 (C-8), 160.96 (C-3), 162.60 (C-6), $182.38(\mathrm{C}-4), 185.47(\mathrm{C}-1)$; $\mathrm{MS}\left(100^{\circ} \mathrm{C}\right): \mathrm{m} / \mathrm{z}(\%)=298\left(100, \mathrm{M}^{+}\right), 283$ (17), 255 (14), 227 (25), 199 (37). Anal. Calcd for $\mathrm{C}_{17} \mathrm{H}_{14} \mathrm{O}_{5}+0.5 \mathrm{H}_{2} \mathrm{O} \mathrm{C}, 66.45 ; \mathrm{H}, 4.92$. Found: $\mathrm{C}, 66.55 ; \mathrm{H}$, 4.53 .

Data for 58. $\mathrm{Mp} 253^{\circ} \mathrm{C}$. IR: $v=1665 \mathrm{~cm}^{-1}(\mathrm{C}=\mathrm{O}), 1645(\mathrm{C}=\mathrm{O}), 1630(\mathrm{C}=\mathrm{C}), 1260,1235$, 1210; UV: $\lambda_{\max }(\lg \varepsilon)=229$ nm (4.348), 299 (4.166), 385 (2.958), 520 (3.113), 630 (2.812); ${ }^{1} \mathrm{H}$ NMR (250 MHz): $\delta=3.91\left(\mathrm{~s}, 3 \mathrm{H}, \mathrm{OCH}_{3}\right), 4.00\left(\mathrm{~s}, 3 \mathrm{H}, \mathrm{OCH}_{3}\right), 4.01\left(\mathrm{~s}, 3 \mathrm{H}, \mathrm{OCH}_{3}\right), 6.12$ 
(s, 1H, 3-H), 6.61 (d, $J=2 \mathrm{~Hz}, 1 \mathrm{H}, 7-\mathrm{H}), 8.04$ (d, $J=9 \mathrm{~Hz}, 1 \mathrm{H}, 10-\mathrm{H}), 8.52$ (d, $J=9 \mathrm{~Hz}, 1 \mathrm{H}$, 9-H), $8.70(\mathrm{~d}, J=2 \mathrm{~Hz}, 1 \mathrm{H}, 5-\mathrm{H}) ;{ }^{13} \mathrm{C} \mathrm{NMR}: \delta=55.61\left(\mathrm{OCH}_{3}\right), 55.75\left(\mathrm{OCH}_{3}\right), 56.18\left(\mathrm{OCH}_{3}\right)$, 97.86 (C-5), 100.15 (C-7), 111.81 (C-3), 119.30 (C-10), 124.89 (C-10), 126.10 (C-8a), 128.33 (C-9), 132.31 (C-4b), 132.49 (C-4a), 156.25 (C-8), 158.10 (C-2), 161.96 (C-6), 180.98 (C-4), 188.36. (C-1); MS: $m / z(\%)=298\left(100, \mathrm{M}^{+}\right), 227$ (50), 199 (62), 152 (32), 141 (46), 126 (32), 113 (42), 69 (42). Anal. Calcd for $\mathrm{C}_{17} \mathrm{H}_{14} \mathrm{O}_{5}: \mathrm{C}, 68.45$; H, 4.73. Found: $\mathrm{C}, 67.98 \mathrm{H} 4.56$.

\section{3,7,8-Trimethoxy-1,4-phenanthrenequinone (64) and 2,7,8-trimethoxy-1,4- phenanthrenequinone (59)}

Data for 79. Mp $227^{\circ} \mathrm{C}$. IR: $v=1670 \mathrm{~cm}^{-1}(\mathrm{C}=\mathrm{O}), 1645(\mathrm{C}=\mathrm{O}), 1620(\mathrm{C}=\mathrm{C}), 1605,1475$, 1275, 1215, 1175, 1090, 840; UV: $\lambda_{\max }(\lg \varepsilon)=231 \mathrm{~nm}$ (4.577), $272 \mathrm{sh}$ (4.129), 301 (4.312), $330 \mathrm{sh}$ (3.692), 382 (3.530), $450 \mathrm{~nm}$ (3.053); ${ }^{1} \mathrm{H}$ NMR: $\delta=3.92$ (s, 3H, $\left.\mathrm{OCH}_{3}\right), 3.99(\mathrm{~s}, 3 \mathrm{H}$, $\left.\mathrm{OCH}_{3}\right), 4.03$ (s, 3H, OCH 3$), 6.09$ (s, 1H, 2-H), 7.49 (d, $\left.J=10 \mathrm{~Hz}, 1 \mathrm{H}, 6-\mathrm{H}\right), 8.12$ (d, $J=8 \mathrm{~Hz}$, $1 \mathrm{H}, 10-\mathrm{H}), 8.48(\mathrm{~d}, J=8 \mathrm{~Hz}, 1 \mathrm{H}, 9-\mathrm{H}), 9.27(\mathrm{~d}, J=10 \mathrm{~Hz}, 1 \mathrm{H}, 5-\mathrm{H}) ;{ }^{13} \mathrm{C} \mathrm{NMR}: \delta=56.40$ $\left(\mathrm{OCH}_{3}\right), 56.46\left(\mathrm{OCH}_{3}\right), 61.32\left(\mathrm{OCH}_{3}\right), 107.13(\mathrm{C}-2), 118.48(\mathrm{C}-6), 121.98(\mathrm{C}-8), 124.43(\mathrm{C}-$ 5), 125.24 (C-10a), 126.14 (C-8a), 128.64 (C-9), 131.02 (C-4b), 132.33 (C-4a), 142.59 (C-8), 150.06 (C-7), 160.60 (C-3), 182.55 (C-4), 185.24 (C-1); MS $\left(120^{\circ} \mathrm{C}\right): \mathrm{m} / \mathrm{z}(\%)=298(100$, $\mathrm{M}^{+}$), 283 (79), 255 (70), 227 (45), 199 (27), 171 (48), 141 (43). Anal. Calcd for $\mathrm{C}_{17} \mathrm{H}_{14} \mathrm{O}_{5}$ : C, 68.45; H, 4.73. Found: C, 68.35; H, 4.53.

Data for 80. Mp $166^{\circ} \mathrm{C}$. IR: $v=1650 \mathrm{~cm}^{-1}(\mathrm{C}=\mathrm{O}), 1640,1630(\mathrm{C}=\mathrm{C}), 1600,1480,1280$, 1240, 1120, 1075; UV: $\lambda_{\max }(\lg \varepsilon)=232 \mathrm{~nm}$ (4.442), $250 \mathrm{sh}$ (4.141), $292 \mathrm{sh}$ (4.144), 303 (4.189), $328 \mathrm{sh}$ (3.671), 385 (3.342), 453 (2.974); ${ }^{1} \mathrm{H}$ NMR: $\delta=3.90$ (s, 3H, $\mathrm{OCH}_{3}$ ), 3.99 (s, $\left.3 \mathrm{H}, \mathrm{OCH}_{3}\right), 4.04\left(\mathrm{~s}, 3 \mathrm{H}, \mathrm{OCH}_{3}\right), 6.10(\mathrm{~s}, 1 \mathrm{H}, 3-\mathrm{H}), 7.46$ (d, $\left.J=9 \mathrm{~Hz}, 1-\mathrm{H}, 6-\mathrm{H}\right), 8.14$ (d, $J=9$ $\mathrm{Hz}, 1 \mathrm{H}, 10-\mathrm{H}), 8.44$ (d, $J=9 \mathrm{~Hz}, 1 \mathrm{H}, 9-\mathrm{H}), 9.36$ (d, $J=9 \mathrm{~Hz}, 1 \mathrm{H}, 5-\mathrm{H}) ;{ }^{13} \mathrm{C} \mathrm{NMR}: \delta=56.23$ $\left(\mathrm{OCH}_{3}\right), 56.48\left(\mathrm{OCH}_{3}\right), 61.32\left(\mathrm{OCH}_{3}\right), 111.12(\mathrm{C}-3), 117.97(\mathrm{C}-6), 122.05(\mathrm{C}-10), 125.19(\mathrm{C}-$ 10a), 125.47 (C-5), 127.27 (C-9), 127.40 (C-8a), 129.56 (C-4b), 132.91 (C-4a), 142.37 (C-8), 150.37 (C-7), 158.31 (C-2), 180.88 (C-4), 188.38 (C-1); MS: m/z (\%)= 298 (5, M+), $196(56)$, 138 (100), 110 (55), 108 (68), 69 (84). Anal. Calcd for $\mathrm{C}_{17} \mathrm{H}_{14} \mathrm{O}_{5}$ : C, 68.45; H, 4.73. Found: C, 68.29; H, 4.70.

3,5,6,7-Tetramethoxy-1,4-phenanthrenequinone (71). Yield: $187 \mathrm{mg}(17 \%), \mathrm{mp} 175^{\circ} \mathrm{C}$. IR: $v=1680 \mathrm{~cm}^{-1}(\mathrm{C}=\mathrm{O}), 1640(\mathrm{C}=\mathrm{O}), 1615(\mathrm{C}=\mathrm{C}), 1605,1470,1425,1275,1200,1165,1125$, 
1090; UV: $\lambda_{\max }(\lg \varepsilon)=244 \mathrm{~nm}$ (4.624), 300 (4.324), 391 (3.590); ${ }^{1} \mathrm{H}$ NMR: $\delta=3.93$ (s, $6 \mathrm{H}$, $\left.\mathrm{OCH}_{3}\right), 4.00\left(\mathrm{~s}, 3 \mathrm{H}, \mathrm{OCH}_{3}\right), 4.07\left(\mathrm{~s}, 3 \mathrm{H}, \mathrm{OCH}_{3}\right), 6.01(\mathrm{~s}, 1 \mathrm{H}, 2-\mathrm{H}), 6.94(\mathrm{~s}, 1 \mathrm{H}, 8-\mathrm{H}), 7.89$ (d, $J=9 \mathrm{~Hz}, 1 \mathrm{H}, 10-\mathrm{H}), 8.03(\mathrm{~d}, J=9 \mathrm{~Hz}, 1 \mathrm{H}, 9-\mathrm{H}) ;{ }^{13} \mathrm{C} \mathrm{NMR}: \delta=56.10\left(\mathrm{OCH}_{3}\right), 56.55$ $\left(\mathrm{OCH}_{3}\right), 60.82\left(\mathrm{OCH}_{3}\right), 61.05\left(\mathrm{OCH}_{3}\right), 102.75(\mathrm{C}-8), 106.27$ (C-2), $120.23(\mathrm{C}-10 \mathrm{a}), 121.35$ (C-10), 131.19 (C-8a), 132.10 (C-9), 134.31 (C-4b), 143.78 (C-4a), 150.04 (C-5), 155.36 (C8), 162.93 (C-3, C-7), 181.80 (C-4), 184.41 (C-1); MS $\left(130^{\circ} \mathrm{C}\right): \mathrm{m} / \mathrm{z}(\%)=328\left(100, \mathrm{M}^{+}\right), 313$ (67), 285 (78), 270 (29), 255 (65), 199 (58). Anal. Calcd for $\mathrm{C}_{18} \mathrm{H}_{16} \mathrm{O}_{6}: \mathrm{C}, 65.85 ; \mathrm{H}, 4.91$. Found: C, 65.26; H 4.85 .

3,5,6,8-Tetramethoxy-1,4-phenanthrenequinone (72). Yield: $103 \mathrm{mg}$ (9\%). mp 200-201 ${ }^{\circ} \mathrm{C}$. IR: $v=1675 \mathrm{~cm}^{-1}(\mathrm{C}=\mathrm{O}), 1650(\mathrm{C}=\mathrm{O}), 1620(\mathrm{C}=\mathrm{C}), 1605,1465,1260,1210,1175,1085$, 1010, 835; UV: $\lambda_{\max }(\lg \varepsilon)=234 \mathrm{~nm}$ (4.523), 303 (4.259), $370 \mathrm{sh}$ (3.161), 505 (3.167); ${ }^{1} \mathrm{H}$ NMR: $\delta=3.94\left(\mathrm{~s}, 6 \mathrm{H}, \mathrm{OCH}_{3}\right), 4.00\left(\mathrm{~s}, 3 \mathrm{H}, \mathrm{OCH}_{3}\right), 4.02\left(\mathrm{~s}, 3 \mathrm{H}, \mathrm{OCH}_{3}\right), 6.02(\mathrm{~s}, 1 \mathrm{H}, 2-\mathrm{H})$, $6.77(\mathrm{~s}, 1 \mathrm{H}, 7-\mathrm{H}), 7.91(\mathrm{~d}, J=8 \mathrm{~Hz}, 1 \mathrm{H}, 10-\mathrm{H}), 8.43(\mathrm{~d}, J=8 \mathrm{~Hz}, 1 \mathrm{H}, 9-\mathrm{H}) ;{ }^{13} \mathrm{C} \mathrm{NMR:} \delta=$ $56.16\left(\mathrm{OCH}_{3}\right), 56.56\left(\mathrm{OCH}_{3}\right), 57.25\left(\mathrm{OCH}_{3}\right), 60.53\left(\mathrm{OCH}_{3}\right), 98.45(\mathrm{C}-7), 106.16(\mathrm{C}-2)$, 118.81 (C-10), 124.26 (C-10a), 125.12 (C-8a), 127.96 (C-9), 130.78 (C-4b), 133.95 (C-4a), 138.87 (C-8), 152.04 (C-5), 152.36 (C-6), 163.28 (C-3), 181.34 (C-4), 184.64 (C-1). MS $\left(125^{\circ} \mathrm{C}\right): \mathrm{m} / \mathrm{z}(\%)=328(100, \mathrm{M}+), 313$ (99), 285 (96), 255 (47), 225 (27), 199 (26), 184 (19). Anal. Calcd for $\mathrm{C}_{18} \mathrm{H}_{16} \mathrm{O}_{6}$ : C, 65.85; H, 4.91. Found: C, 65.00; H, 4.82.

\section{3,6,7,8-Tetramethoxy-1,4-phenanthrenequinone (74) and 2,6,7,8-tetramethoxy-1,4- phenanthrenequinone (70)}

Yields: $74509 \mathrm{mg}$ (46\%); $7042 \mathrm{mg}$ ( 4\%).

Data for 74. $\mathrm{mp} 195^{\circ} \mathrm{C}$. IR: $v=1665 \mathrm{~cm}^{-1}(\mathrm{C}=\mathrm{O}), 1645(\mathrm{C}=\mathrm{O}), 1620(\mathrm{C}=\mathrm{C}), 1480,1360$, 1260, 1245, 1230, 1120, 1080; UV: $\lambda_{\max }(\lg \varepsilon)=212 \mathrm{~nm} \mathrm{sh}$ (4.394), 240 (4.698), 289 (4.235), 297 (4.242), 322 (3.663); ${ }^{1} \mathrm{H}$ NMR: $\delta=3.94\left(\mathrm{~s}, 3 \mathrm{H}, \mathrm{OCH}_{3}\right), 4.03$ (s, 3H, $\left.\mathrm{OCH}_{3}\right), 4.07$ (s, 6H, $\left.\mathrm{OCH}_{3}\right), 6.11(\mathrm{~s}, 1 \mathrm{H}, 2-\mathrm{H}), 8.01(\mathrm{~d}, J=9 \mathrm{~Hz}, 1 \mathrm{H}, 10-\mathrm{H}), 8.45$ (d, $\left.J=9 \mathrm{~Hz}, 1 \mathrm{H}, 9-\mathrm{H}\right), 8.88$ (s, $1 \mathrm{H}, 5 \mathrm{H}) ;{ }^{13} \mathrm{C} \mathrm{NMR}: \delta=55.99\left(\mathrm{OCH}_{3}\right), 56.48\left(\mathrm{OCH}_{3}\right), 61.07\left(\mathrm{OCH}_{3}\right), 61.66\left(\mathrm{OCH}_{3}\right), 102.21$ (C-5), 107.21 (C-2), 119.98 (C-10), 124.01 (C-10a), 127.87 (C-8a), 128.44 (C-4b), 129.04 (C9), 132.46 (C-4a), 142.33 (C-8), 147.53 (C-7), 156.86 (C-6), 160.67 (C-3), 182.59 (C-4), $185.28(\mathrm{C}-1)$; $\operatorname{MS}\left(130^{\circ} \mathrm{C}\right): \mathrm{m} / \mathrm{z}(\%)=328\left(100, \mathrm{M}^{+}\right), 313$ (76), 297 (13), 285 (76), 270 (62), 255 (38), 242 (41), 227 (42), 199 (56). Anal. Calcd for $\mathrm{C}_{18} \mathrm{H}_{16} \mathrm{O}_{6}$ : C, 65.85; H, 4.91. Found: C, 64.93; H, 4.65 . 
Data for 82. Mp $217^{\circ} \mathrm{C}$. IR: $v=1675 \mathrm{~cm}^{-1}(\mathrm{C}=\mathrm{O}), 1635(\mathrm{C}=\mathrm{O}), 1620(\mathrm{C}=\mathrm{C}), 1480,1240$, 1130, 1075; UV: $\lambda_{\max }(\lg \varepsilon)=238 \mathrm{~nm}$ (4.584), 298 (4.289), $320 \mathrm{sh}$ (3.717), 405 (3.543).

${ }^{1} \mathrm{H}$ NMR: $\delta=3.91\left(\mathrm{~s}, 3 \mathrm{H}, \mathrm{OCH}_{3}\right), 4.02\left(\mathrm{~s}, 3 \mathrm{H}, \mathrm{OCH}_{3}\right), 4.04\left(\mathrm{~s}, 3 \mathrm{H}, \mathrm{OCH}_{3}\right), 4.08(\mathrm{~s}, 3 \mathrm{H}$, $\left.\mathrm{OCH}_{3}\right), 6.09$ (s, 1H, 3-H), 8.05 (d, $\left.J=9 \mathrm{~Hz}, 1 \mathrm{H}, 10-\mathrm{H}\right), 8.38$ (d, $\left.J=9 \mathrm{~Hz}, 1 \mathrm{H}, 9-\mathrm{H}\right), 8.93$ (s, 1H, 5-H); ${ }^{13} \mathrm{C}$ NMR: $\delta=56.01\left(\mathrm{OCH}_{3}\right), 56.15\left(\mathrm{OCH}_{3}\right), 61.04\left(\mathrm{OCH}_{3}\right), 61.88\left(\mathrm{OCH}_{3}\right), 102.82$ (C-5), 111.39 (C-3), 120.12 (C-10), 125.22 (C-10a), 126.96 (C-8a), 127.55 (C-9), 129.28 (C4b), 131.16 (C-4a), 142.29 (C-8), 147.39 (C-7), 156.38 (C-6), 158.41 (C-2), 186.44 (C-4), 189.89 (C-1); $\operatorname{MS}\left(100^{\circ} \mathrm{C}\right): m / z(\%)=313$ (45), 285 (31), 270 (19), 199 (12). Anal. Calcd for $\mathrm{C}_{18} \mathrm{H}_{16} \mathrm{O}_{6}: \mathrm{C}, 65.85 ; \mathrm{H}, 4.91$. Found: C, 65.43; H, 5.34.

9,10-Dihydro-3,5,7-trimethoxy-1,4-phenanthrenequinone (80). Yield: $377 \mathrm{mg}$ (37\%), mp $189^{\circ} \mathrm{C}$. IR: $v=1680 \mathrm{~cm}^{-1}(\mathrm{C}=\mathrm{O}), 1630(\mathrm{C}=\mathrm{C}), 1600,1560,1285,1230,1195,1135$; UV: $\lambda_{\max }$ $(\lg \varepsilon)=219 \mathrm{~nm}$ (4.389), 262 (4.191), $272 \mathrm{sh}$ (4.121), $287 \mathrm{sh}$ (4.012), 326 (3.655), 475 (3.443); ${ }^{1} \mathrm{H}$ NMR: $\delta=2.62(\mathrm{~s}, 4 \mathrm{H}, 9-, 10-\mathrm{H}), 3.79\left(\mathrm{~s}, 3 \mathrm{H}, \mathrm{OCH}_{3}\right), 3.83\left(\mathrm{~s}, 3 \mathrm{H}, \mathrm{OCH}_{3}\right), 3.83(\mathrm{~s}, 3 \mathrm{H}$, $\left.\mathrm{OCH}_{3}\right), 5.86(\mathrm{~s}, 1 \mathrm{H}, 2-\mathrm{H}), 6.64(\mathrm{~s}, 2 \mathrm{H}, 6-, 8-\mathrm{H}) ;{ }^{13} \mathrm{C}$ NMR: $\delta=20.50(\mathrm{C}-10), 28.90$ (C-9), $55.44\left(\mathrm{OCH}_{3}\right), 55.87\left(\mathrm{OCH}_{3}\right), 56.22\left(\mathrm{OCH}_{3}\right), 97.71(\mathrm{C}-8), 105.80(\mathrm{C}-6), 105.81(\mathrm{C}-2), 112.20$ (C-10a), 139.01 (C-8a), 140.55 (C-4b), 142.44 (C-4a), 158.52 (C-5), 159.87 (C-7), 162.22 (C3), 180.33 (C-4), 185.83 (C-1); MS (100 $\left.{ }^{\circ} \mathrm{C}\right): m / z=300\left(100 \%, \mathrm{M}^{+}\right), 285$ (35), 257 (99), 242 (59), 215 (63), 128 (71), 115 (93); Anal. Calcd for $\mathrm{C}_{17} \mathrm{H}_{16} \mathrm{O}_{5}$ : C, 67.99; H, 5.37. Found: C, 68.07; H, 5.40 .

\section{2,3,7,8-Tetramethoxy-1,4-phenanthrenequinone (69) and 9,10-dihydro-2,3,7,8-} tetramethoxy-1,4-phenanthrenequinone (81)

Yields: 69, $263 \mathrm{mg}(24 \%) ; \mathbf{8 1}, 140 \mathrm{mg}(12 \%)$.

Data for 87. Mp $157{ }^{\circ} \mathrm{C}$. IR: $v=1663 \mathrm{~cm}^{-1}(\mathrm{C}=\mathrm{O}), 1632(\mathrm{C}=\mathrm{C}), 1610,1480,1282,1229$, 1214, 1202, 1080, 1047, 1020; UV: $\lambda_{\max }(\lg \varepsilon)=231 \mathrm{~nm}$ (4.624), $256 \mathrm{sh}$ (4.126), 305 (4.385), 354 (3.748); ${ }^{1} \mathrm{H}$ NMR (400 MHz): $\delta=3.99\left(\mathrm{~s}, 3 \mathrm{H}, \mathrm{OCH}_{3}\right), 4.05\left(\mathrm{~s}, 3 \mathrm{H}, \mathrm{OCH}_{3}\right), 4.11(\mathrm{~s}, 3 \mathrm{H}$, $\left.\mathrm{OCH}_{3}\right), 4.14\left(\mathrm{~s}, 3 \mathrm{H}, \mathrm{OCH}_{3}\right), 7.50$ (d, $\left.J=10 \mathrm{~Hz}, 1 \mathrm{H}, 6-\mathrm{H}\right), 8.14$ (d, $\left.J=9 \mathrm{~Hz}, 1 \mathrm{H}, 10-\mathrm{H}\right), 8.46$ (d, $J=9 \mathrm{~Hz}, 1 \mathrm{H}, 9-\mathrm{H}), 9.29$ (d, $J=10 \mathrm{~Hz}, 1 \mathrm{H}, 5-\mathrm{H})$; MS $\left(110^{\circ} \mathrm{C}\right): \mathrm{m} / \mathrm{z}(\%)=328\left(100, \mathrm{M}^{+}\right)$, 313 (44), 285 (19), 171 (15). Anal. Calcd for $\mathrm{C}_{18} \mathrm{H}_{16} \mathrm{O}_{6}$ : C, 65.85; H, 4.91. Found: C, 65.93; $\mathrm{H}, 4.65$. 
Data for 81. Mp $125^{\circ} \mathrm{C}$. IR: $v=1669 \mathrm{~cm}^{-1}(\mathrm{C}=\mathrm{O}), 1638(\mathrm{C}=\mathrm{C}) .1592,1490,1275,1228$, 1149, 1071, 1040, 1004; UV: $\lambda_{\max }(\lg \varepsilon)=214 \mathrm{~nm}$ (4.449), 259 (4.267), 350 (3.831), 494 (3.336); ${ }^{1} \mathrm{H}$ NMR (400 MHz): $\delta=2.74\left(\mathrm{~m}_{\mathrm{c}}, 4 \mathrm{H}, 9-, 10-\mathrm{H}\right), 4.04$ (s, 3H, $\left.\mathrm{OCH}_{3}\right), 4.06$ (s, 3H, $\left.\mathrm{OCH}_{3}\right), 6.85(\mathrm{~d}, J=9 \mathrm{~Hz}, 1 \mathrm{H}, 6-\mathrm{H}), 7.81(\mathrm{~d}, J=9 \mathrm{~Hz}, 1 \mathrm{H}, 5-\mathrm{H}) ; \mathrm{MS}\left(100^{\circ} \mathrm{C}\right): \mathrm{m} / \mathrm{z}(\%)=330$ (100, $\mathrm{M}^{+}$), 315 (42), 299 (27), 259 (16); Anal. Calcd for $\mathrm{C}_{18} \mathrm{H}_{18} \mathrm{O}_{6}$ : C, 65.45; H, 5.49. Found: C, 65.43; H, 5.34.

\section{General procedure 4. Aromatization of 9,10-dihydro-1,4-phenanthrenchinones to 1,4-} phenanthrenchinones

A mixture of the 9,10-dihydro-1,4-phenanthrenequinone $(0,77 \mathrm{mmol})$ and palladium on charcoal $(5 \%, 43 \mathrm{mg})$ was heated to $180-190{ }^{\circ} \mathrm{C}$ for $2-3 \mathrm{~h}$ (TLC monitoring). The melt was dissolved in dichloromethane, filtered, purified by flash chromatography on silica gel and crystallized from dichloromethane/petroleum ether.

3,5,7-Trimethoxy-1,4-phenanthrenequinone (60). Yield from $230 \mathrm{mg}(0.77 \mathrm{mmol})$ of 80, $218 \mathrm{mg}(95 \%) . \mathrm{mp} 167^{\circ} \mathrm{C} . \mathrm{IR}: \mathrm{v}=1685 \mathrm{~cm}^{-1}(\mathrm{C}=\mathrm{O}), 1645(\mathrm{C}=\mathrm{O}), 1615(\mathrm{C}=\mathrm{C}), 1280,1245$, 1210, 1165, 1095; UV: $\lambda_{\max }(\lg \varepsilon)=228 \mathrm{~nm}$ sh (4.392), 237 (4.415), 302 (4.308), 377 (3.368); ${ }^{1} \mathrm{H}$ NMR (300 MHz): $\delta=3.93\left(\mathrm{~s}, 3 \mathrm{H}, \mathrm{OCH}_{3}\right), 3.94\left(\mathrm{~s}, 3 \mathrm{H}, \mathrm{OCH}_{3}\right), 3.95\left(\mathrm{~s}, 3 \mathrm{H}, \mathrm{OCH}_{3}\right), 6.01$ (s, 1H, 2-H), 6.71 (d, $J=2 \mathrm{~Hz}, 1 \mathrm{H}, 6-\mathrm{H}), 6.78$ (d, $J=2 \mathrm{~Hz}, 1 \mathrm{H}, 8-\mathrm{H}), 7.89$ (d, $J=8 \mathrm{~Hz}, 1 \mathrm{H}$, $10-\mathrm{H}), 8.06(\mathrm{~d}, J=8 \mathrm{~Hz}, 1 \mathrm{H}, 9-\mathrm{H}) ;{ }^{13} \mathrm{C} \mathrm{NMR}: \delta=55.59\left(\mathrm{OCH}_{3}\right), 55.98\left(\mathrm{OCH}_{3}\right), 56.47$ $\left(\mathrm{OCH}_{3}\right), 99.32$ (C-6), 102.07 (C-9), 106.29 (C-3), 117.04 (C-10a), 122.64 (C-10), 130.91 (C8a), 132.26 (C-9), 132.91 (C-4b), 139.04 (C-4a), 158.29 (C-5), 160.93 (C-7), 163.01 (C-3), $181.76(\mathrm{C}-4), 184.56(\mathrm{C}-1)$; MS (100 C): m/z (\%) = $298\left(100, \mathrm{M}^{+}\right), 283$ (31), 227 (24), 199 (28). Anal. Calcd for $\mathrm{C}_{17} \mathrm{H}_{14} \mathrm{O}_{5}$ : C, 68.45; H, 4.73. Found: C, 68.29; H, 4.56.

7,8-Dimethoxy-1,4-phenanthrenequinone (54). Yield form $208 \mathrm{mg}(0.77 \mathrm{mmol})$ of 90 (29 mg recovered): $167 \mathrm{mg}(94 \%)$. Data see above.

\section{5-Hydroxy-3,7-dimethoxy-1,4-phenanthrenequinone (3) (Denbinobin)}

A solution of 3,5,7-trimethoxy-1,4-phenanthrenequinone (60) (50 $\mathrm{mg}, 017 \mathrm{mmol})$ in dichloromethane $(1 \mathrm{~mL})$ was treated with iodotrimethylsilane $(0.4 \mathrm{~mL})$. The mixture was stirred for 15 min (TLC monitoring) and quenched by addition of methanol ( $1 \mathrm{~mL})$. The and the solvent removed under reduced pressure and the residue redissolved in diethyl ether (10 
$\mathrm{mL})$. The solution was washed with water $(3 \mathrm{~mL})$ and brine $(3 \mathrm{~mL})$, dried $\left(\mathrm{CaCl}_{2}\right)$, filtered and the solvent removed under reduced pressure. The residue was purified by preparative TLC chromatography on silica gel $(1 \mathrm{~mm}$, dichloromethane) and the phenolic product crystallized from dichloromethane/petroleum ether to yield denbinobin (3) $35 \mathrm{mg}$ (72\%), mp $215^{\circ} \mathrm{C}$ (ref. ${ }^{21}$ m.p. $\left.215^{\circ} \mathrm{C}\right)$. IR: $v=1645 \mathrm{~cm}^{-1}(\mathrm{C}=\mathrm{O}), 1630(\mathrm{C}=\mathrm{O}), 1615(\mathrm{C}=\mathrm{C}), 1335,1245$, 1175, 1085; UV: $\lambda_{\max }(\lg \varepsilon)=237 \mathrm{~nm}$ (4.527), 310 (4.328), 401 (3.407); UV (Ethanol): $\lambda_{\max }$ $(\lg \varepsilon)=240 \mathrm{~nm}$ (4.512), 312 (4.329), 403 (3.407); ${ }^{1} \mathrm{H}$ NMR (300 MHz): $\delta=3.94$ (s, $3 \mathrm{H}$, $\left.\mathrm{OCH}_{3}\right), 3.97$ (s, 3H, $\left.\mathrm{OCH}_{3}\right), 6.17(\mathrm{~s}, 1 \mathrm{H}, 2-\mathrm{H}), 6.83(\mathrm{~d}, J=3 \mathrm{~Hz}, 1 \mathrm{H}, 8-\mathrm{H}), 6.94(\mathrm{~d}, J=3 \mathrm{~Hz}$, 1H, 6-H), 8.08 (d, $J=9 \mathrm{~Hz}, 1 \mathrm{H}, 10-\mathrm{H}), 8.14$ (d, $J=9 \mathrm{~Hz}, 1 \mathrm{H}, 9-\mathrm{H}), 11.00$ (s, 1H, OH), MS $\left(120^{\circ} \mathrm{C}\right): \mathrm{m} / \mathrm{z}(\%)=284\left(100, \mathrm{M}^{+}\right), 213(63), 185(34)$.

9,10-Dihydro-5-hydroxy-3,7-dimethoxy-1,4-phenanthrenequinone (94). 9,10-Dihydro3,5,7-trimethoxy-1,4-phenanthrenequinone (80) $(51 \mathrm{mg}, 0.17 \mathrm{mmol})$ were treated with iodotrimethylsilane as described for 3 to yield the phenolic dihydro-1,4-phenanthrenequinone 94 (30 mg, 62\%), mp $172^{\circ} \mathrm{C}$. IR: $v=1645 \mathrm{~cm}^{-1}(\mathrm{C}=\mathrm{O}), 1615(\mathrm{C}=\mathrm{C}), 1555,1430,1310,1240$, 1220, 1205, 1130; UV: $\lambda_{\max }(\lg \varepsilon)=221 \mathrm{~nm}$ (4.380), 259 (4.140), $269 \mathrm{sh}$ (4.089), $283 \mathrm{sh}$ (4.016), 314 (3.822), 476 (3.363); ${ }^{1} \mathrm{H}$ NMR (400 MHz): $\delta=2.67$ (s, 4H, 9-, 10-H), 3.81 (s, $\left.3 \mathrm{H}, \mathrm{OCH}_{3}\right), 5.99(\mathrm{~s}, 1 \mathrm{H}, 2-\mathrm{H}), 6.41(\mathrm{~d}, J=3 \mathrm{~Hz}, 1 \mathrm{H}, 8-\mathrm{H}), 6.46(\mathrm{~d}, J=3 \mathrm{~Hz}, 1 \mathrm{H}, 6-\mathrm{H}), 8.85$ $(\mathrm{s}, 1 \mathrm{H}, \mathrm{OH}) ; \mathrm{MS}\left(120^{\circ} \mathrm{C}\right): \mathrm{m} / \mathrm{z}(\%)=286\left(100, \mathrm{M}^{+}\right), 271(41), 243$ (49). Anal. Calcd for $\mathrm{C}_{16} \mathrm{H}_{14} \mathrm{O}_{5}(286.29)+0.5 \mathrm{H}_{2} \mathrm{O}$ C, 65.08; H, 5.12. Found: C, 65.31; H, 4.84 .

\section{Thiele-Winter reaction with 1,4-phenanthrenequinones, saponification and methylation,}

\section{General procedure 4}

A solution of 1,4-phenanthrenequinone $(0.15 \mathrm{mmol})$ in acetic anhydride $(4 \mathrm{~mL})$ was treated with perchloric acid $(0.15 \mathrm{~mL})$. The reaction was quenched after $15 \mathrm{~min}$ by addition of icewater $(30 \mathrm{~g})$. The mixture was stirred for $1 \mathrm{~h}$ to hydrolyze the anhydride and then extracted with dichloromethane $(10 \mathrm{~mL})$. The organic phase was washed with water $(5 \mathrm{~mL})$ and brine $(5 \mathrm{~mL})$, dried $\left(\mathrm{CaCl}_{2}\right)$, filtered and the solvent removed under reduced pressure. The residue was dissolved in methanol $(1 \mathrm{~mL})$ and saponified by addition of $1 \mathrm{~N} \mathrm{NaOMe}(0.6 \mathrm{~mL})$. After $15 \mathrm{~min}$ the solution was acidified by addition of $1 \mathrm{~N} \mathrm{HCl}(1 \mathrm{~mL})$. The suspension was extracted with dichloromethane, the organic phase was dried $\left(\mathrm{CaCl}_{2}\right)$, filtered and the solvent removed under reduced pressure. The residue was purified by preparative TLC 
chromatography on silica gel and the products crystallized from dichloromethane /petroleum ether. Yields and $\mathrm{mp}$ see Scheme 4.

2-Methoxy-1,4-phenanthrenequinone (41) and 3-methoxy-1,4-phenanthrenequinone (1). 1,4-Phenanthreneqionone (36 $\mathrm{mg}, 0.15 \mathrm{mmol}$ ) was converted to the methoxy-1,4phenanthreneqionones 41 and 1 in (31\%) (39\%) yield, respectively.

2,7,8-Trimethoxy-1,4-phenanthrenequinone (59) and 3,7,8-Trimethoxy-1,4phenanthrenequinone (64). According to the general procedure VI, 8-benzyloxy-7-methoxy1,4-phenanthrenequinone (55) (52 $\mathrm{mg}, 0.15 \mathrm{mmol}$ ) was converted to the quinones 59 and 64 in $11 \%$ and $18 \%$ yield, respectively. With one equivalent of diazomethane solution the monophenols 95 and 96 were isolated ( 9 and $16 \%$ yield, respectively)

8-Hydroxy-2,7-dimethoxy-1,4-phenanthrenequinone (95). Mp $249^{\circ} \mathrm{C}$. IR: $v=3530 \mathrm{~cm}^{-1}$ $(\mathrm{OH}), 1665(\mathrm{C}=\mathrm{O}), 1625(\mathrm{C}=\mathrm{C}), 1585,1480,1260,1240,1115,1065$; UV: $\lambda_{\max }(\lg \varepsilon)=222$ $\mathrm{nm}$ sh (4.435), 235 (4.475), 274 (4.021), 314 (4.312), 395 (3.272), 512 (2.989).

${ }^{1} \mathrm{H}$ NMR (400 MHz): $\delta=3.91\left(\mathrm{~s}, 3 \mathrm{H}, \mathrm{OCH}_{3}\right), 4.06\left(\mathrm{~s}, 3 \mathrm{H}, \mathrm{OCH}_{3}\right), 6.04(\mathrm{~s}, 1 \mathrm{H}, \mathrm{OH}), 6.12(\mathrm{~s}$, $1 \mathrm{H}, 3-\mathrm{H}), 7.44$ (d, $J=10 \mathrm{~Hz}, 1 \mathrm{H}, 6-\mathrm{H}), 8.15$ (d, $J=9 \mathrm{~Hz}, 1 \mathrm{H}, 10-\mathrm{H}), 8.50$ (dd, $J_{9,10}=9 \mathrm{~Hz}$, $\left.J_{5,9}=1 \mathrm{~Hz}, 1 \mathrm{H}, 9-\mathrm{H}\right), 9.19\left(\mathrm{dd} ; J_{5,6}=10 \mathrm{~Hz}, J_{5,9}=1 \mathrm{~Hz}, 1 \mathrm{H}, 5-\mathrm{H}\right) ; \mathrm{Ms}: m / z(\%)=284(100$, $\mathrm{M}^{+}$), 269 (51), 241 (53), 213 (17), 185 (16), 170 (17). Anal. Calcd for $\mathrm{C}_{16} \mathrm{H}_{12} \mathrm{O}_{5}: \mathrm{C}, 67.60 ; \mathrm{H}$, 4.25. Found: $\mathrm{C}, 67.55 ; \mathrm{H}, 4.12$.

8-Hydroxy-3,7-dimethoxy-1,4-phenanthrenequinone (96). Mp $286^{\circ} \mathrm{C}$. IR: $v=3480 \mathrm{~cm}^{-1}$ $(\mathrm{OH}), 1670,1655(\mathrm{C}=\mathrm{O}), 1620(\mathrm{C}=\mathrm{C}), 1485,1290,820$; UV: $\lambda_{\max }(\lg \varepsilon)=231 \mathrm{~nm}(4.487)$, 273 (4.078), 311 (4.257), 391 (3.359), 516 (2.908); ${ }^{1} \mathrm{H}$ NMR (400 MHz): $\delta=3.93$ (s, 3H, $\left.\mathrm{OCH}_{3}\right), 4.06$ (s, 3H, $\left.\mathrm{OCH}_{3}\right), 6.07$ (s, 1H, OH), 6.12 (s, 1H, 2-H), 7.49 (d, J=10 Hz, 1H, 6-H), $8.15(\mathrm{~d}, J=9 \mathrm{~Hz}, 1 \mathrm{H}, 10-\mathrm{H}), 8.58\left(\mathrm{dd}, J_{9,10}=9 \mathrm{~Hz}, J_{5,9}=1 \mathrm{~Hz}, 1 \mathrm{H}, 9-\mathrm{H}\right), 9.13$ (dd, $J_{5,6}=10$ $\left.\mathrm{Hz}, J_{5,9}=1 \mathrm{~Hz}, 1 \mathrm{H}, 5-\mathrm{H}\right)$; MS: m/z (\%) = $284\left(100, \mathrm{M}^{+}\right), 269$ (50), 241 (41), 213 (12), 185 (14), 170 (15). Anal. Calcd for $\mathrm{C}_{16} \mathrm{H}_{12} \mathrm{O}_{5}: \mathrm{C}, 67.60, \mathrm{H}, 4.25$. Found: C, 66.95; H, 4.18.

7-Hydroxy-3,8-dimethoxy-1,4-phenanthrenequinone (97), 2-hydroxy-7,8-dimethoxy-1,4phenanthrenequinone (98) and 3-hydroxy-7,8-dimethoxy-1,4-phenanthrene-quinone (99). $52 \mathrm{mg}(0.15 \mathrm{mmol})$ of 7-benzyloxy-8-methoxy-1,4-phenanthrenequinone (56) was 
converted according to general procedure VI. The crude product was separated by preparative TLC to give two fractions: Quinone 97 (4 mg, 9\%) and a mixture of quinones 98 and 99 (3 $\mathrm{mg}, 7 \%)$.

Data for 97. Mp: $250-251^{\circ} \mathrm{C}$. IR: $v=3480 \mathrm{~cm}^{-1}(\mathrm{OH}), 1640(\mathrm{C}=\mathrm{O}), 1620(\mathrm{C}=\mathrm{C}), 1480,1250$, 1180, 1140; UV: $\lambda_{\max }(\lg \varepsilon)=207 \mathrm{~nm}$ sh (4.172), 233 (4.526), 266 (4.127), 305 (4.237), 390 (3.475); ${ }^{1} \mathrm{H}$ NMR (400 MHz): $\delta=3.93\left(\mathrm{~s}, 3 \mathrm{H}, \mathrm{OCH}_{3}\right), 3.97\left(\mathrm{~s}, 3 \mathrm{H}, \mathrm{OCH}_{3}\right), 5.98(\mathrm{~s}, 1 \mathrm{H}, \mathrm{OH})$, $6.14(\mathrm{~s}, 1 \mathrm{H}, 2-\mathrm{H}), 7.47$ (d, $J=10 \mathrm{~Hz}, 1 \mathrm{H}, 6-\mathrm{H}), 8.22$ (d, $J=10 \mathrm{~Hz}, 1 \mathrm{H}, 10-\mathrm{H}), 8.34$ (dd, $J_{9,10}$ $\left.=10 \mathrm{~Hz}, J_{5,9}=1 \mathrm{~Hz}, 1 \mathrm{H}, 9-\mathrm{H}\right), 9.29\left(\mathrm{dd}, J_{5,6}=10 \mathrm{~Hz}, J_{5,9}=1 \mathrm{~Hz}, 1 \mathrm{H}, 5-\mathrm{H}\right) ; \mathrm{Ms}\left(130^{\circ} \mathrm{C}\right): \mathrm{m} / \mathrm{z}$ $(\%)=284\left(76, \mathrm{M}^{+}\right), 269$ (77), 241 (37), 192 (24), 123 (24), 84 (100). Anal. Calcd for $\mathrm{C}_{16} \mathrm{H}_{12} \mathrm{O}_{5} ; \mathrm{C}, 67.60 ; \mathrm{H}, 4.25$. Found: $\mathrm{C}, 66.73 ; \mathrm{H}, 4.20$.

Data for 98 and 99. $\mathrm{Mp} 262{ }^{\circ} \mathrm{C} .{ }^{1} \mathrm{H}$ NMR $(400 \mathrm{MHz}): \delta=3.93\left(\mathrm{~s}, 3 \mathrm{H}, \mathrm{OCH}_{3}\right), 3.95(\mathrm{~s}, 3 \mathrm{H}$, $\left.\mathrm{OCH}_{3}\right), 3.98\left(\mathrm{~s}, 3 \mathrm{H}, \mathrm{OCH}_{3}\right), 3.99$ (s, 3H, $\left.\mathrm{OCH}_{3}\right), 6.13$ (s, 1H, 2- o. 3-H), 6.15 (s, 1H, 2- o. 3H), $7.44(\mathrm{~d}, J=9 \mathrm{~Hz}, 1 \mathrm{H}, 6-\mathrm{H}), 7.47$ (d, $J=9 \mathrm{~Hz}, 1 \mathrm{H}, 6-\mathrm{H}), 8.22$ (d, $J=9 \mathrm{~Hz}, 1 \mathrm{H}, 10-\mathrm{H})$, $8.26(\mathrm{~d}, J=9 \mathrm{~Hz}, 1 \mathrm{H}, 9-\mathrm{H}), 8.34(\mathrm{~d}, J=9 \mathrm{~Hz}, 1 \mathrm{H}, 5-\mathrm{H}) . \mathrm{Ms}\left(125^{\circ} \mathrm{C}\right): \mathrm{m} / \mathrm{z}(\%)=284\left(97, \mathrm{M}^{+}\right)$, 269 (100), 241 (46), 84 (67).

\section{Epoxidation of 1,4-phenanthrenchinones. General procedure 7}

A solution of the 1,4-phenanthrenchinone $(0.19 \mathrm{mmol})$ in ethanol $(5 \mathrm{~mL})$ was treated at $45^{\circ} \mathrm{C}$ with $0.53 \mathrm{~mL}$ of $30 \% \mathrm{H}_{2} \mathrm{O}_{2}$ and $0.53 \mathrm{~mL}$ of saturated $\mathrm{Na}_{2} \mathrm{CO}_{3}$ solution. After $5 \mathrm{~min}$, the mixture was poured into ice-water $(30 \mathrm{~g})$ and extracted with extracted five times with dichloromethane $(20 \mathrm{~mL})$. The combined organic phases were dried $\left(\mathrm{CaCl}_{2}\right)$, filtered, and the solvent removed under reduced pressure. The products were crystallized from dichloromethane / petroleum ether.

2,3-Epoxy-2,3-dihydro-8-methoxy-1,4-phenanthrenequinone (100). $45 \mathrm{mg}$ (0.19 mmol) of 8-methoxy-1,4-phenanthrenequinone (46) was converted to the epoxide 100. Yield $38 \mathrm{mg}$ (79\%). Mp 218 ${ }^{\circ} \mathrm{C}$ (decomp.). IR: $v=1695 \mathrm{~cm}^{-1}(\mathrm{C}=\mathrm{O}), 1575,1315,1295,1270,1245$ (Epoxid), 750; UV: $\lambda_{\max }(\lg \varepsilon)=221 \mathrm{~nm}$ (4.361), 283 (4.403), 328 (3.312), 392 (3.332); ${ }^{1} \mathrm{H}$ $\operatorname{NMR}(300 \mathrm{MHz}): \delta=4.03\left(\mathrm{~s}, 3 \mathrm{H}, \mathrm{OCH}_{3}\right), 4.10(\mathrm{~d}, J=4 \mathrm{~Hz}, 1 \mathrm{H}, 2-\mathrm{H}), 4.15(\mathrm{~d}, J=4 \mathrm{~Hz}, 1 \mathrm{H}$, 3-H), $7.00(\mathrm{~d}, J=8 \mathrm{~Hz}, 1 \mathrm{H}, 7-\mathrm{H}), 7.62\left(\mathrm{dd}, J_{5,6}=8 \mathrm{~Hz}, J_{6,7}=8 \mathrm{~Hz}, 1 \mathrm{H}, 6-\mathrm{H}\right), 7.94(\mathrm{~d}, J=9$ $\mathrm{Hz}, 1 \mathrm{H}, 10-\mathrm{H}), 8.45$ (d, $J=9 \mathrm{~Hz}, 1 \mathrm{H}, 9-\mathrm{H}), 8.67$ (d, $J=8 \mathrm{~Hz}, 1 \mathrm{H}, 5-\mathrm{H}) ; \mathrm{MS}\left(100^{\circ} \mathrm{C}\right): \mathrm{m} / \mathrm{z}(\%)$ : 
$254\left(100, \mathrm{M}^{+}\right.$), 226 (16), 211 (16), 183 (37), 127 (22), 113 (15). Anal. Calcd for $\mathrm{C}_{15} \mathrm{H}_{10} \mathrm{O}_{4}$ : C, 70.87; H, 3.96. Found: C, 70.37, H, 4.02.

2,3-Epoxy-2,3-dihydro-7,8-dimethoxy-1,4-phenanthrenequinone (101). 51 mg (0.19 mmol) of 7,8-dimethoxy-1,4-phenanthrenequinone (54) was converted to the epoxide 101. Yield: $44 \mathrm{mg}(81 \%) . \mathrm{mp} 165^{\circ} \mathrm{C}$. IR: $v=1695 \mathrm{~cm}^{-1}(\mathrm{C}=\mathrm{O}), 1480,1280$ (epoxide); UV: $\lambda_{\max }(\lg$ $\varepsilon)=219 \mathrm{~nm}$ (4.354), 288 (4.503), 373 (3.548); ${ }^{1} \mathrm{H}$ NMR: $\delta=3.96\left(\mathrm{~s}, 3 \mathrm{H}, \mathrm{OCH}_{3}\right), 4.07(\mathrm{~s}, 3 \mathrm{H}$, $\left.\mathrm{OCH}_{3}\right), 4.05(\mathrm{~d}, J=5 \mathrm{~Hz}, 1 \mathrm{H}, 2 \mathrm{H}), 4.12(\mathrm{~d}, J=5 \mathrm{~Hz}, 1 \mathrm{H}, 3-\mathrm{H}), 7.43$ (d, $\left.J=10 \mathrm{~Hz}, 1 \mathrm{H}, 6-\mathrm{H}\right)$, $7.87(\mathrm{~d}, J=9 \mathrm{~Hz}, 1 \mathrm{H}, 10-\mathrm{H}), 8.44$ (d, $J=9 \mathrm{~Hz}, 1 \mathrm{H}, 9-\mathrm{H}), 8.63$ (d, $J=10 \mathrm{~Hz}, 1 \mathrm{H}, 5-\mathrm{H})$; MS $\left(120^{\circ} \mathrm{C}\right): \mathrm{m} / \mathrm{z}(\%)=284\left(100, \mathrm{M}^{+}\right), 269$ (63), 149 (50), 97 (58), 83 (61), 69 (94), 57 (78), 43 (87). Anal. Calcd for $\mathrm{C}_{16} \mathrm{H}_{12} \mathrm{O}_{5}$ : C, 67.60; H, 4.25. Found: C, 67.76; H, 4.34.

2,3-Epoxy-2,3-dihydro-6,7,8-trimethoxyphenanthren-1,4-dion (102). $57 \mathrm{mg}$ (0.19 mmol) 6,7,8-trimethoxy-1,4-phenanthrenequinone (67) was converted to the epoxide 102. Yield 36 mg (60\%). mp $133^{\circ} \mathrm{C}$. IR: $v=1690 \mathrm{~cm}^{-1}(\mathrm{C}=\mathrm{O}), 1680,1475,1410,1270$ (Epoxid), 1245, 1130, 1120, 1035; UV: $\lambda_{\max }(\lg \varepsilon)=216$ nm (4.458), 237 (4.374), 292 (4.405), 356 (3.650); ${ }^{1} \mathrm{H}$ NMR (300 MHz): $\delta=4.03\left(\mathrm{~s}, 3 \mathrm{H}, \mathrm{OCH}_{3}\right), 4.05\left(\mathrm{~s}, 3 \mathrm{H}, \mathrm{OCH}_{3}\right), 4.09(\mathrm{~d}, J=4 \mathrm{~Hz}, 1 \mathrm{H}, 2-$ H), $4.12(\mathrm{~d}, J=4 \mathrm{~Hz}, 1 \mathrm{H}, 3-\mathrm{H}), 7.85$ (d, $J=9 \mathrm{~Hz}, 1 \mathrm{H}, 10-\mathrm{H}), 8.22$ (s, 1H, 5-H), 8.43 (d, $J=9$ $\mathrm{Hz}, 1 \mathrm{H}, 9-\mathrm{H}) ; \mathrm{MS}\left(70^{\circ} \mathrm{C}\right): \mathrm{m} / \mathrm{z}(\%): 314$ (100, $\left.\mathrm{M}^{+}\right), 299$ (34), 271 (31), 256 (17). Anal. Calcd for $\mathrm{C}_{17} \mathrm{H}_{14} \mathrm{O}_{6}$ : C, 64.97, $\mathrm{H}, 4.49$. C, 64.70; H, 4.50.

\section{cis-Hydroxylation of 54. 2,3-dihydro-2,3-dihydroxy-7,8-dimethoxyphenanthrene-1,4- dione (103)}

A solution of 7,8-dimethoyxy-1,4-phenanthrenequinone (54) in THF (2 mL) was treated at 20 ${ }^{\circ} \mathrm{C}$ with an aqueous solution of osmium tetroxide $(2 \%, 1.4 \mathrm{~mL})$ and sodium chlorate $(61 \mathrm{mg})$. The mixture was stirred for $3 \mathrm{~h}$. Part of the diol 103 precipitated and was filtered of. Another crop was obtained by extraction with dichloromethane and usual workup. Yield $150 \mathrm{mg}$ (89 \%); mp $185^{\circ} \mathrm{C}$. IR: $1690(\mathrm{CO}), 1680(\mathrm{C}=\mathrm{O}), 1605(\mathrm{C}=\mathrm{C}), 1590,1480,1275,1085,1035$, 815; UV: $\lambda_{\max }(1 \mathrm{~g} \varepsilon)=223$ (4.354), 284 (4.583), 365 (3.637); ${ }^{1} \mathrm{H}-\mathrm{NMR}: \delta=3.90$ (s; $\left.3 \mathrm{H}, \mathrm{OCH}_{3}\right), 4.01\left(\mathrm{~s} ; 3 \mathrm{H}, \mathrm{OCH}_{3}\right), 4.46(\mathrm{~s} ; 2 \mathrm{H}, 2-\mathrm{u} .3-\mathrm{H}), 7.73(\mathrm{~d}, \mathrm{~J}=10 \mathrm{~Hz} ; 1 \mathrm{H}, 6-\mathrm{H}), 7.98$ (d, J $=9 \mathrm{~Hz} ; 1 \mathrm{H}, 10-\mathrm{H}), 8.42(\mathrm{~d}, \mathrm{~J}=9 \mathrm{~Hz} ; 1 \mathrm{H}, 9-\mathrm{H}), 8.86(\mathrm{~d}, \mathrm{~J}=10 \mathrm{~Hz} ; 1 \mathrm{H}, 5-\mathrm{H}) ; \mathrm{MS}\left(160^{\circ} \mathrm{C}\right): \mathrm{m} / e$ $=302\left(100 \%, \mathrm{M}^{+}\right), 286(33), 256(39), 241(44), 186(51), 171(44), 115(63)$. 


\section{2,3-Dihydro-7,8-dimethoxy-2,3-cis-isopropylidendioxyphenanthren-1,4-dion (104)}

A solution of diol $103(20 \mathrm{mg}, 0.07 \mathrm{mmol}), 0.03 \mathrm{~mL}$ of orthoformic methyl ester, and $4 \mathrm{mg}$ of p-toluenesulfonic acid in dry acetone $(0.5 \mathrm{~mL})$ was refluxed for $30 \mathrm{~min}$. The solvent was removed under reduced pressure, the residue redissolved in dichloromethane, washed with water, dried $\left(\mathrm{CaCl}_{2}\right)$, and the solvent removed under reduced pressure. The residue was purified by preparative TLC on silica gel to afford $15 \mathrm{mg}$ of acetonide 104 (63\%), mp 161 ${ }^{\circ} \mathrm{C}$. IR: $1715(\mathrm{C}=0), 1690(\mathrm{C}=0), 1605(\mathrm{C}=\mathrm{C}), 1480,1280,1215,1085,985$, 825; UV: $\lambda_{\max }$ $(1 \mathrm{~g} \varepsilon)=220$ (4.400), 239 (4.458), 254 sh (4.271), 291 (4.115), 332 sh (3.609), 351 (3.525); ${ }^{1} \mathrm{H}-\mathrm{NMR}: \delta=1.46\left(\mathrm{~s} ; 3 \mathrm{H}, \mathrm{CH}_{3}\right), 1.49\left(\mathrm{~s} ; 3 \mathrm{H}, \mathrm{CH}_{3}\right), 3.97\left(\mathrm{~s} ; 3 \mathrm{H}, \mathrm{OCH}_{3}\right), 4.02\left(\mathrm{~s} ; 3 \mathrm{H}, \mathrm{OCH}_{3}\right)$, 5.01 (s; 2H, 2-u.3-H), $7.47(\mathrm{~d}, \mathrm{~J}=10 \mathrm{~Hz} ; 1 \mathrm{H}, 6-\mathrm{H}), 8.00(\mathrm{~d}, \mathrm{~J}=9 \mathrm{~Hz} ; 1 \mathrm{H}, 10-\mathrm{H}), 8.46(\mathrm{~d}, \mathrm{~J}=$ 9Hz; 1H, 9-H), $8.70(\mathrm{~d}, \mathrm{~J}=10 \mathrm{~Hz} ; 1 \mathrm{H}, 5-\mathrm{H}) ; \mathrm{MS}\left(140^{\circ} \mathrm{C}\right): \mathrm{m} / \mathrm{e}=342\left(100 \%, \mathrm{M}^{+}\right), 256(65)$, 241 (66), 213 (31), 171 (24), 84 (94).

\section{Stilbene-cyclizations. General procedure 5}

The stilbenes 84-87 were prepared by Wittig reaction of the aldehydes 11, 13, and 17 with the phosphonium salts 82 and $\mathbf{8 3}$ according to the General Procedure I (modification of Boden. ${ }^{42}$ ). A solution of the stilbene $(1.3 \mathrm{mmol})$ in freshly distilled cyclohexene $(130 \mathrm{~mL})$ and $0.07 \mathrm{~mol}$ of iodine was irradiated in a water-cooled photoreactor with $360 \mathrm{~nm}$ light until the starting material was consumed (TLC control). The intermediate phenanthrenes were purified by flash chromatography on silica gel (dichloromethane), crystallized and directly subjected to the oxidative CAN demethylation.

\section{Oxidative CAN demethylations. General procedure 8}

A solution of the phenanthrene $(0.4 \mathrm{mmol})$ in a mixture of water $(0.6 \mathrm{~mL})$ and acetonitrile $(1.4 \mathrm{~mL})$ was treated with $0.2 \mathrm{~g}$ of pyridine-2,6-dicarboxylic acid N-oxide ${ }^{53}$ and a solution of ceriumammonium nitrate (CAN, $0.5 \mathrm{~g}$ ) in $2 \mathrm{~mL}$ of acetonitrile/water (1:1). The mixture was stirred for $30 \mathrm{~min}$ at $0{ }^{\circ} \mathrm{C}$ (TLC control) and quenched with water after conversion of the starting material. The product was extracted with dichloromethane, purified by flash chromatography on silica gel and crystallized.

7-Methoxy-1,4-phenanthrenquinone (45). Yield $97 \%$. mp $154{ }^{\circ} \mathrm{C}\left(\right.$ ref. $\left.^{29}: 153{ }^{\circ} \mathrm{C}\right)$.

7,8-Dimethoxy-1,4-phenanthrenquinone (51). Yield $91 \%$. mp $190{ }^{\circ} \mathrm{C}\left(\operatorname{ref}^{29}: 196-198{ }^{\circ} \mathrm{C}\right)$. 
2,7,8-Trimethoxy-1,4-phenanthrenquinone (59). Yield: $10 \%$; mp $184-186{ }^{\circ} \mathrm{C}$.

2,6,7-Trimethoxy-1,4-Phenanthrenquinone (92). Yield $14 \%$; mp above $250{ }^{\circ} \mathrm{C}$ (decomp.). ${ }^{1} \mathrm{H}$ NMR $\left(90 \mathrm{MHz}, \mathrm{CDCl}_{3}\right): \delta=3.96 ; 4.09 ; 4.15 ;\left(3 \mathrm{~s}, 3 \mathrm{H}, \mathrm{OCH}_{3}\right) ; 6.13(\mathrm{~s}, 1 \mathrm{H}, \mathrm{Ar}-\mathrm{H}) ; 7.1(\mathrm{~s}$, $1 \mathrm{H}, \operatorname{Ar}-\mathrm{H})$; AB-signal $\left(\delta_{\mathrm{A}}=7.75 ; \delta_{\mathrm{B}}=8.24 ; J=9 \mathrm{~Hz}\right.$; Ar-H); 9.69 (s, 3H, Ar-H); UV (methanol): $\lambda_{\max }(\lg \varepsilon)=243 \mathrm{~nm}$ (4.43); 278 (3.93); 285 (3.91); 298 (3.88); 318 (3.60); 425 (3.52). Anal. Calcd for $\mathrm{C}_{17} \mathrm{H}_{14} \mathrm{O}_{5}$ : C, 68.45; H, 4.73. Found: C, 68.82; H, 4.66.

7,8-Dimethoxy-1,2-phenanthrenquinone (93). $\mathrm{mp} 185-186{ }^{\circ} \mathrm{C} .{ }^{1} \mathrm{H} \mathrm{NMR}\left(400 \mathrm{MHz}, \mathrm{CDCl}_{3}\right.$ ): $\delta=4.0\left(\mathrm{~s}, 3 \mathrm{H}, \mathrm{OCH}_{3}\right) ; 4.06\left(\mathrm{~s}, 3 \mathrm{H}, \mathrm{OCH}_{3}\right) ; \mathrm{AX}$-signal $\left(\delta_{\mathrm{A}}=6.53 ; \delta_{\mathrm{X}}=8.22 ; J=11 \mathrm{~Hz} ; \mathrm{Ar}-\right.$ $\mathrm{H}) ; \mathrm{AX}$-signal $\left(\delta_{\mathrm{A}}=7.45 ; \delta_{\mathrm{X}}=8.23 ; J=9 \mathrm{~Hz}, \mathrm{Ar}-\mathrm{H}\right) ; \mathrm{AB}$-signal $\left(\delta_{\mathrm{A}}=8.01 ; \delta_{\mathrm{B}}=8.09 ; J=10\right.$ $\mathrm{Hz}, \mathrm{Ar}-\mathrm{H})$; IR (KBr): $1665 \mathrm{~cm}^{-1}(\mathrm{C}=\mathrm{O}), 1600(\mathrm{C}=\mathrm{C}), 1480,1280,1080,1030,850,790,750$. Anal. Calcd for $\mathrm{C}_{16} \mathrm{H}_{12} \mathrm{O}_{4}$ : C, 71.64; H, 4.51. Found: C, 72.04; H, 4.43.

\section{Cyclic voltammograms}

A $0.1 \mathrm{~m}$ solution of tetrabutylammonium (TBAP) perchlorate in acetonitrile ${ }^{60}$ was used as electrolyte. The solution was dried with $\mathrm{N}$ super alumina (Woelm) inside the electrochemical cell as described. ${ }^{61}$ The cell was equipped with following electrodes: Working electrode: 1 $\mathrm{mm}$ diameter platinum disk; auxiliary electrode: platinum spiral; Reference electrode: $\mathrm{Ag} / \mathrm{Ag}+/ \mathrm{TBAP}-\mathrm{MeCN}$. Electrochemical data was determined with a home built computer controlled apparatus. For data of cyclic voltammograms from ten different 1,4phenanthrenequinones $(\mathbf{1}, \mathbf{4 1 - 4 6 , 5 4 , 6 4 , 7 0 , 7 4 )}$ see Table 3.

\section{References}

1. Wu, T.; Jong, T.-T.; Tien, H.-J.; Kuoh, C.-S.; Furukawa, H.; Lee, K.-H. Phytochem. 1987, 26, 1623.

2. Reisch, J.; Báthory, B.; Navák, J.; Szendrei, K.; Minker, E. Herba Hungarica 1972, 11, 61.

3. Schmalle, H. W.; Hausen, B. M. Naturwissenschaften 1979, 66, 527.

4. Criodian, T. O.; O'Sullivan, M.; Meegan, M. J.; Donnelly, D. M. X. Phytochem. 1981, 20, 1089 . 
5. Singh, S. B.; Petit, G. R. J. Am. Chem. Soc. 1989, 111, 4105.

6. Fisch, M. H.; Flick, B. H.; Arditti, J. Phytochemistry 1973, 12, 437.

7. Letcher, R. M.; Nhamo, L. R. M. J. Chem. Soc. 1973, 1263.

8. Hardegger, E.; Schellenbaum, M.; Corrodi, H. Helv. Chim. Acta 1963, 46, 1171.

9. Steiner, K.; Egli, C.; Rigassi, N.; Helali, S. E.; Hyrdegger, E. Helv. Chim. Acta 1974, 57, 1137.

10. Schmalle, H. W.; Jarchow, O. H.; Hausen, B. M.; Schulz, K.-H. Funkt. Biol. Med. 1983, $2,9$.

11. Hardegger, E.; Biland, H. R.; Corrodi, H. Helv. Chim. Acta 1963, 46, 1354.

12. Stermitz, F. R.; Suess, T. R.; Schauer, C. K.; Anderson, O. P. J. Natur. Prod. 1983, 46, 417.

13. Griesebach, H.; Ebel, J. Angew. Chem. 1978, 90, 668; Angew. Chem. Int. Ed. 1978, 17, 635.

14. Reisch, J.; Báthory, M.; Novák, I.; Szendrei, K. Herba Hung. 1970, 9, 43.

15. Hausen, B. M. Woods Injurious to Human Health; de Gruyter.

16. Letcher, R. M.; Nhamo, L. R. M. J. Chem. Soc. C 1971, 3070.

17. Hausen, B. M. Toxic and Sensitizing Orchids In Orchid Biology; Arditti, J., Ed.; Cornell Press, 1984; Vol. 3, p. 262.

18. Bhandari, S. R.; Kapadi, A. H. Phytochem. 1983, 22, 747.

19. Tuchinda, P.; Udchachon, J.; Khumtaveeporn, K.; Taylor, W. C.; Engelhardt, L. M.; White, A. Phytochem. 1988, 27, 3267.

20. Bartsch, H.-H.; Schmalle, H. W.; Jarchow, O. H.; Hausen, B. M.; Schulz, K. H. Acta. Cryst. 1986, C42, 322.

21. Talapatra, B.; Mukhopadhyay, P.; Chaudhurry, P.; Talapatra, S. K. Indian J. Chem. 1982, 21B, 386.

22. Alder, A. C.; Rüedi, P.; Eugster, C. H. Helv. Chim. Acta 1984, 67, 1003.

23. Alder, A. C.; Rüedi, P.; Prewo, R.; Bieri, J. H.; Eugster, C. H. Helv. Chim. Acta 1986, 69, 1395.

24. Chang, H. M.; Cheng, K. P.; Choang, T. F.; Chow, H. F.; Chui, K. Y.; Hon, P. M.; Tan, F. W. L.; Yang, Y. J. Org. Chem. 1990, 55, 3537.

25. Thomson, R. H. Naturally Occurring Quinones III. Recent Advances; Chapman and Hall, 1987. 
26. Babock, H. H. Pharmacist 1875, 8, 1.

27. MacDouglas, D. T. Minnesota Bot. Stud. 1894, 1, 32.

28. Hausen, B. M. unpublished results.

29. Manning, W. B.; Kelly, T. P.; Muschik, G. M. J. Org. Chem. 1980, 45, 2535.

30. Inouye, Y.; Kakisawa, H. Bull. Soc. Chim. Jpn. 1971, 44, 563.

31. Rosen, B. I.; Weber, W. P. J. Org. Chem. 1977, 42, 3463.

32. Engler, T. E.; Sampath, U.; Naganathan, S.; Vander Velde, D.; Takusagawa, F.; Yohannes, D. J. Org. Chem. 1989, 54, 5712.

33. Engler, T. A.; Letavic, M. A.; Reddy, J. P. J. Am. Chem. Soc. 1991, 113, 5068.

34. Blatter, K.; Schlüter, A.; Wegner, G J. Org. Chem. 1989, 54, 2396.

35. Carreno, M. C.; Mahugo, J.; Urbano, A. Tetrahedron Lett. 1977, 38, 3047.

36. Manning, W. B.; Tomaszewski, J. E.; Muschik, G. M.; Sato, R. I. J. Org. Chem. 1977, 42, 3465 .

37. Mallory, F. B.; Wood, C. S.; Gordon, J. T. J. Am. Chem. Soc. 1964, 86, 3094.

38. Kelly, T. R.; Jagoe, C. T.; Li, Q. J. Org. Chem. 1989, 111, 4522.

39. Blackburn, E. V.; Timmons, C. J. Q. Rev., Chem. Soc. 1969, 23, 482.

40. Laarhoven, W. H.; Prinsen, W. J. Top. Curr. Chem. 1984, 125, 63.

41. Kraus, G. A.; Melekhov:, A. J. Org. Chem. 1999, 64, 1720.

42. Boden, R. M. Synthesis 1976, 784.

43. Merz, H.; Fink, G. Arch. Pharm. Ber. dtsch. Pharm. Ges. 1956, 289, 347.

44. Kemp, Weiz oder.

45. Hudson, B. J. F.; Robinson, R. J. Chem. Soc. 1941, 715.

46. Bruckner, V. Ber. 1942, 75, 2034.

47. Lora-Tamayo, M. Tetrahedron 1958, 4, 17.

48. Wagner-Jauregg, T. Synthesis 1980, 769.

49. Cosmo, R.; Hambley, T. W.; Sternhell, S. J. Org. Chem. 1987, 52, 3119.

50. Mannschreck, A.; Gmahl, E.; Burgemeister, T.; Kastner, F.; Sinnwell, V. Angew. Chem. 1988, 100, 299; Angew. Chem. Int. Ed. 1988, 27, 270.

51. Schmalle, H. W.; Jarchow, O. H.; Hausen, B. M.; Schulz, K.-H.; Krohn, K.; Loock, U. Actra. Cryst. 1987, C43, 109.

52. Schmalle, H. W.; Jarchow, O. H.; Hausen, B. M.; Schulz, K.-H.; Krohn, K.; Loock, U. Acta. Cryst. 1986, C42, 1039. 
53. Syper, L.; Kloc, K.; Mlochowski, J.; Szulc, Z. Synthesis 1979, 521.

54. Jacob, P.; III; Callery, P. S.; Shulgin, A. T.; Castagnoli Jr., N. J. Org. Chem. 1976, 41, 3627.

55. Jung, M. E.; Syster, M. A. J. Org. Chem. 1977, 42, 3761.

56. McOmie, J. F. W.; Blatchly, M. J. Org. React. 1972, 19, 2007.

57. Thiele, J. Ber. 1898, 31, 1247.

58. Rashid, A.; Read, G. J. Chem. Soc. (C) 1967, 1223.

59. Mondon, A.; Krohn, K. Chem. Ber. 1972, 105, 3726.

60. Kiesele, H. Anal. Chem. 1980, 52, 2230.

61. Kiesele, H. Anal. Chem. 1981, 53, 1952.

62. The first cathodic peak potentials (Epc1, see Figure 3) are ca. 28.5 to $50 \mathrm{mV}$ (according to kinetics) more negative than E0. The peak potentials are used for the correlation with the LUMO energies.

63. Frenz, B. A. SDP, Enraf-Nonius Structure Determination; Package. SDP User's Guide, Version 1982; Enraf- Nonius: Delft, The Netherlands.

64. Additional material to this paper can be ordered referring to the No. CSD 52795, names of the authors and citation of the paper at the Fachinformationszentrum Energie-PhysikMathematik, D-7514 Eggenstein - Leopoldshafen 2, FRG. 